UNIVERSITY ]OF CALIFORNIA PUBLICATIONS

COLLEGE OF AGRICULTURE AGRICULTURAL EXPERIMENT STATION BERKELEY, CALIFORNIA

\title{
GROWTH OF EUCALYPTUS IN CALIFORNIA PLANTATIONS
}

BY

WOODBRIDGE METCALF

BULLETIN No. 380

November, 1924 


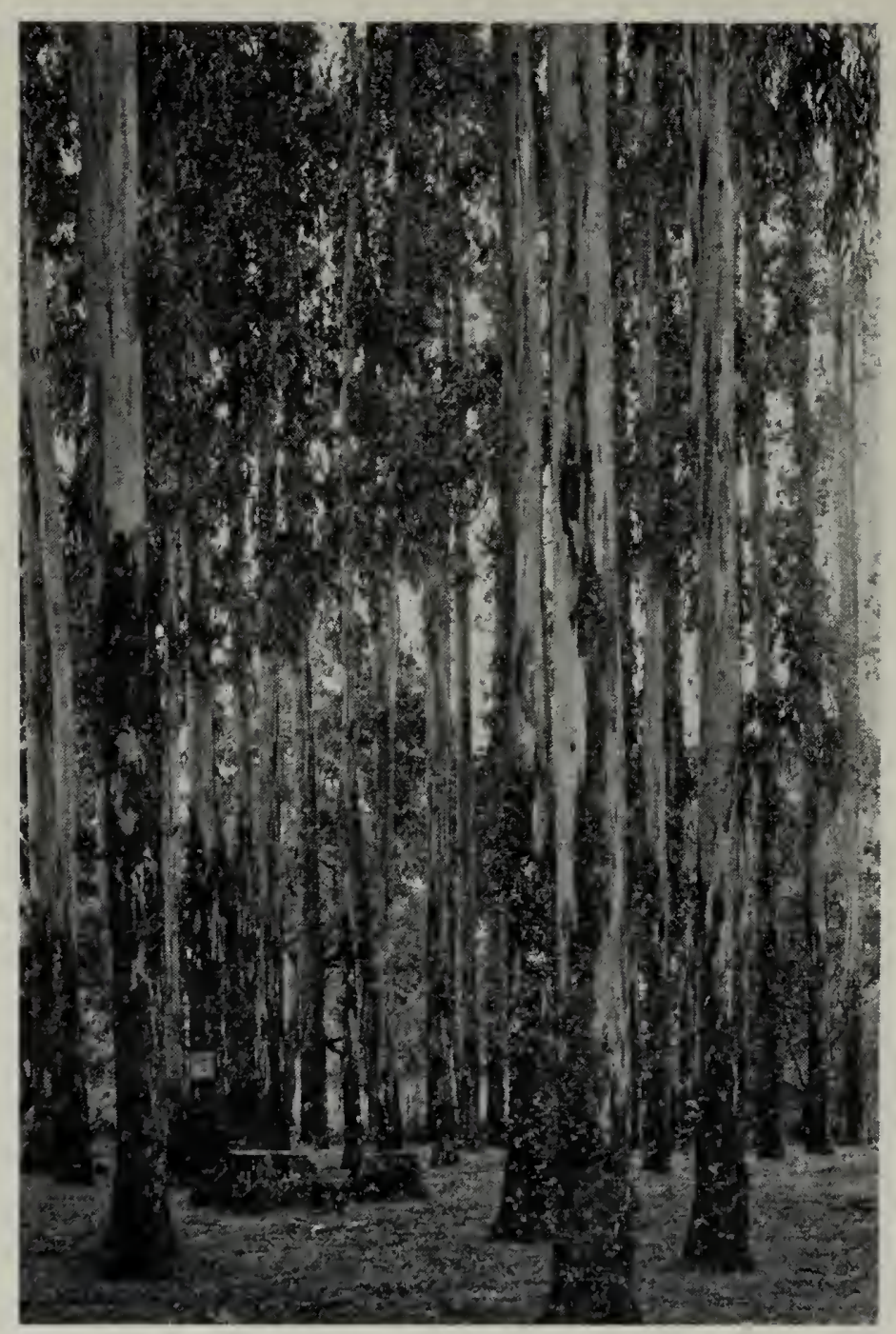

EUCALYP'TUS GROVE ON CAMPUS

Blue Gum, 37 years old, under optimum conditions. 


\title{
GROWTH OF EUCALYPTUS IN CALIFORNIA PLANTATIONS
}

\author{
BY WOODBRIDGE METCALF
}

\section{CONTENTS}

PAGE

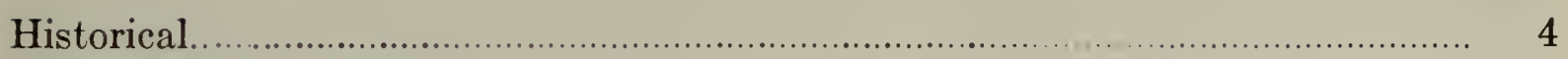

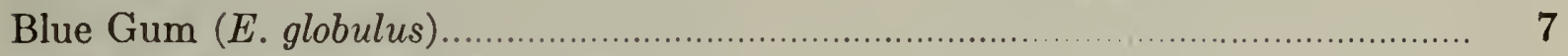

A Yield Table for Blue Gum .............................................................. 10

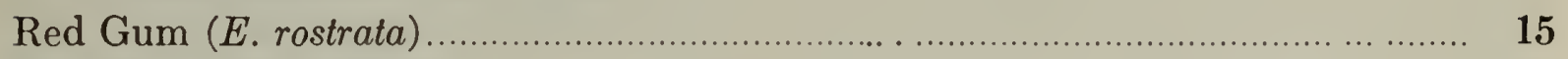

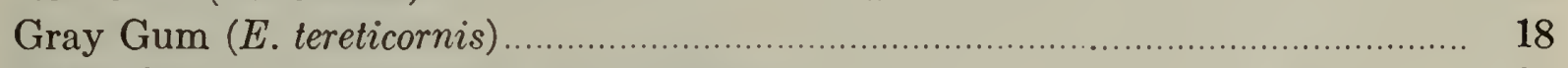

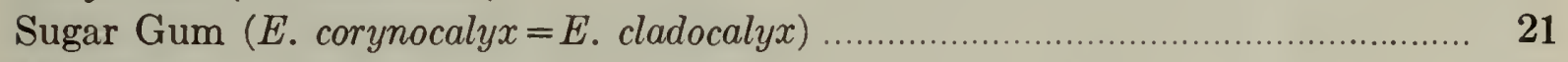

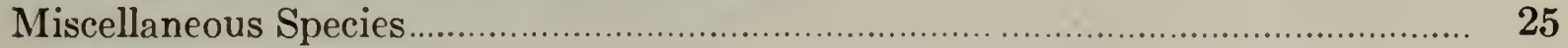

Manna Gum (E. viminalis) ............................................................... 25

Red Ironbark (E. sideroxylon) ........................................................... 27

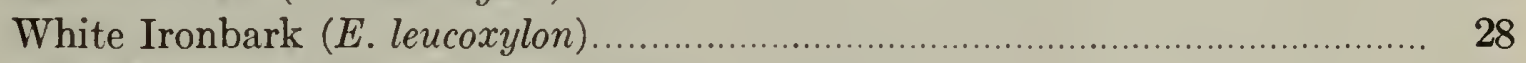

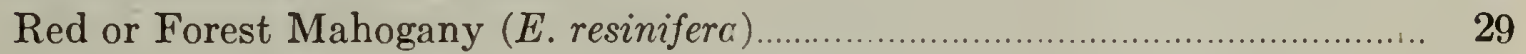

Sydney Blue Gum or Flooded Gum (E. saligna)........................................ 29

Swamp Mahogany (E. botryoides) ..................................................... 29

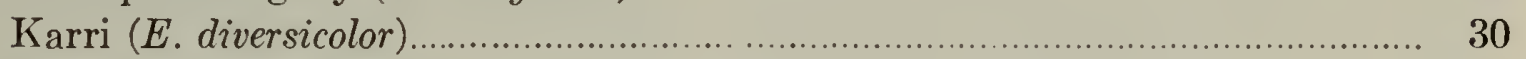

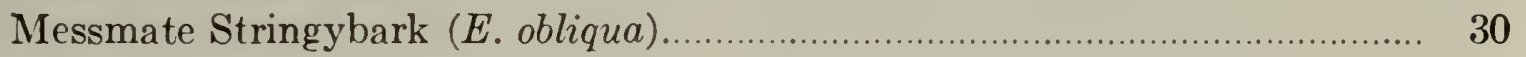

Utilization:

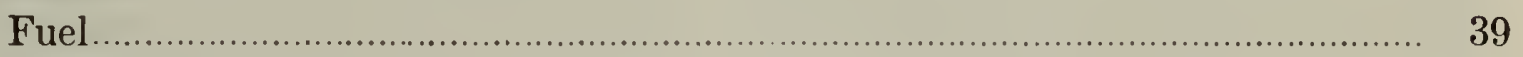

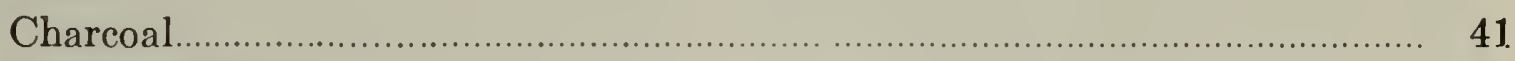

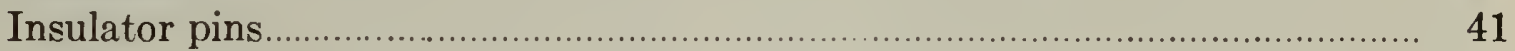

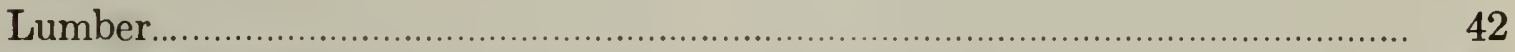

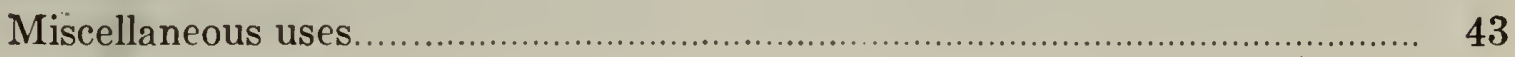

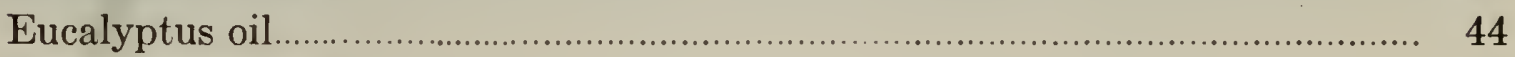

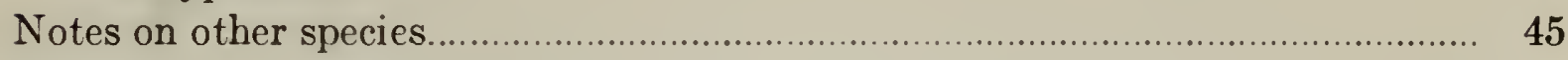

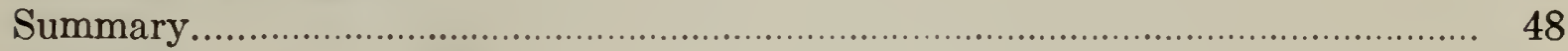

Appendix:

I. Method of taking field measurements............................................ 49

Calculation of volume (table A) ................................................. 51

II. Site classification-E. globulus................................................. 52

III. Raising eucalyptus from seed...................................................... 54

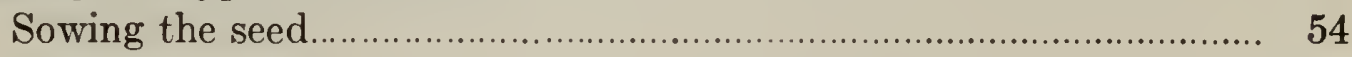

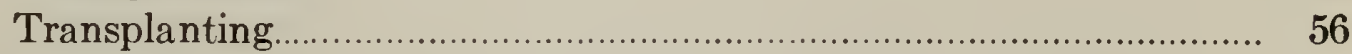

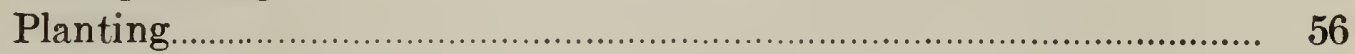

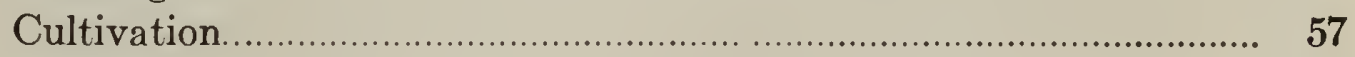

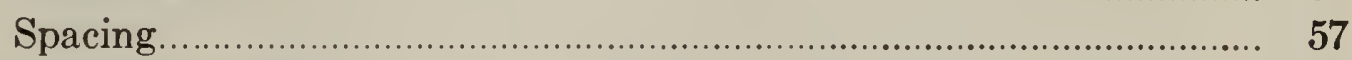

Cost of planting........................................................................ 57

Protection of plantations......................................................... 58 
Trees of the genus Eucalyptus were introduced into California about the year 1860 and since that time have been so extensively used in plantations, windbreaks, and ornamental plantings, that they have become one of the most conspicuous features of the California landscape. The introduction of the trees into the state has been variously attributed to a Mr. Walker of San Francisco, Bishop William Taylor

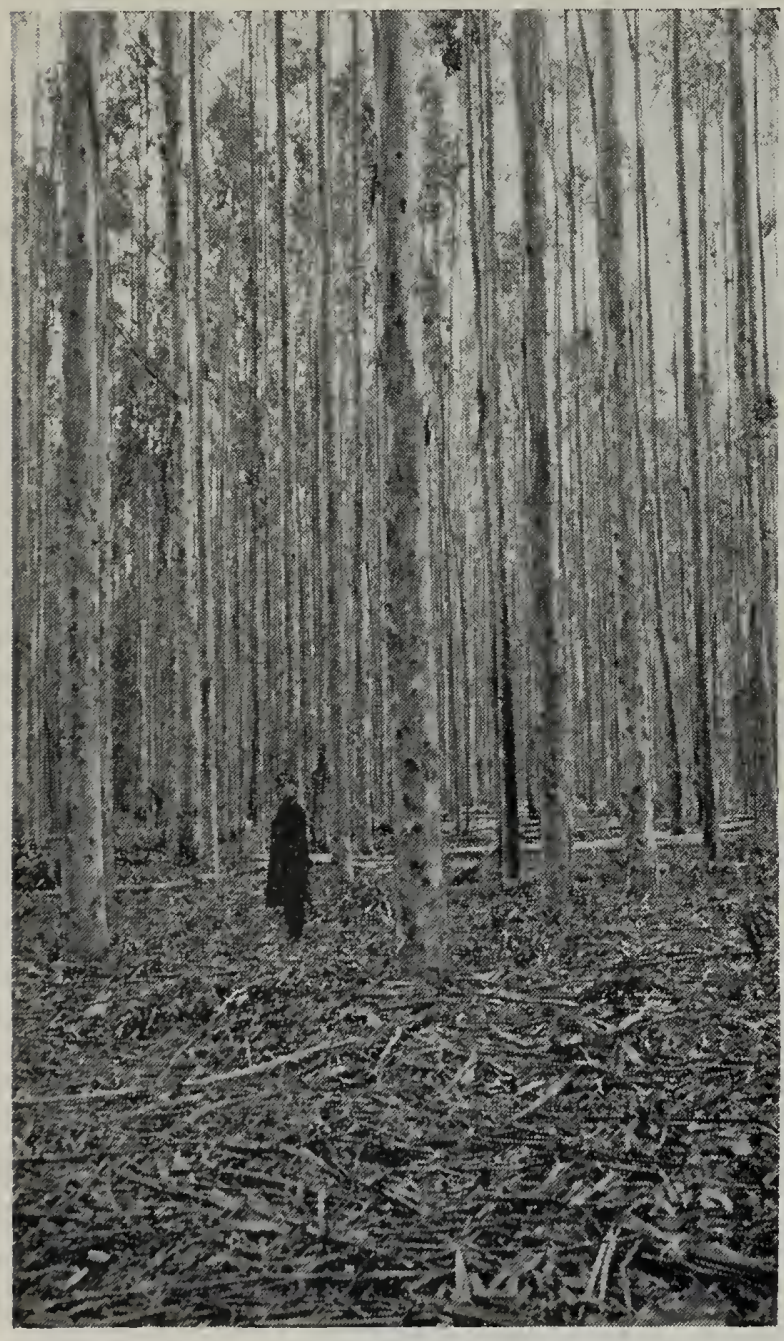

Fig. 1.

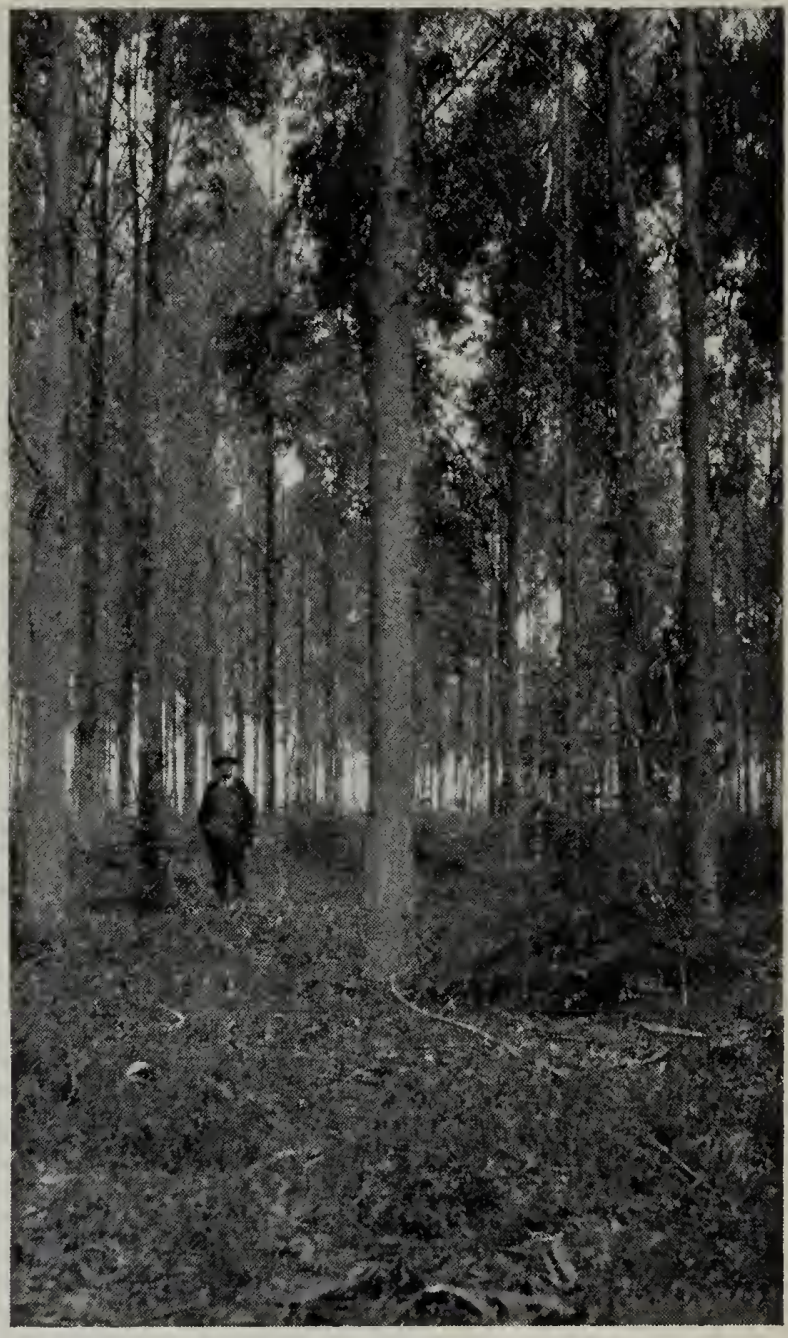

Fig. 2.

Fig. 1.-A Blue Gum grove 23 years old near Stony Point, Sonoma County. The trees average over 10 inches d.b.h., and over 100 feet in height. An example of good growth of this species on sandy loam soil in the coast region.

Fig. 2.-A Blue Gum grove 20 years old on sandy land known locally as Dow's Prairie near McKinleyville, Humboldt County. The spacing is $12 \times 12$ feet and the openness of the crown cover has favored the natural reproduction of native conifers including Douglas Fir, Grand Fir, Western Hemlock, and Bishop Pine.

of the Methodist Church, Nurseryman Nolan of Alameda, and others. Ijp to the present there seems to be no definite historical record as to just who did bring the first seeds to California, but the names of Ellwood Cooper of Santa Barbara, 'T. P. Lukens of Pasadena, and $\Lambda$ bbott Kinney of Venice, are prominent among those who did experi- 
mental planting and urged the extensive use of these trees throughout the state. In later years F. C. Havens of Oakland, Wm. H. Brintnall of Los Angeles and W. D. Patterson of Arden, are among those who made experimental plantings with a number of species which supplement the experimental work of the University of California and the United States Forest Service.

Undoubtedly the first seeds brought into California were of the Blue Gum, Eucalyptus globulus, and the early tests with this species showed it to be so thoroughly at home under the new conditions, and so rapid in its growth, that most of the planting was confined to this tree. This fact seems rather strange as this species has never been considered of much commercial value in either Tasmania or Victoria where it is native, and where mature trees of much larger dimensions are found than any grown thus far under California conditions. The first trees planted were usually set out singly or in narrow belts, and their rapidity of growth gave rise to many exaggerated statements as to the probable financial returns from plantations. Well meaning but over-enthusiastic persons made estimates of growth of plantations by assuming that each tree planted therein would grow as rapidly as trees in the open under optimum soil, moisture, and light conditionsforgetting entirely the influences exerted by different types of soil and climate, the percentage of loss in established plantations, and the slowing up in rate of growth because of competition between trees growing under crowded plantation conditions.

The period 1900-10 was characterized by very great interest in Eucalyptus planting which resulted in the formation of a number of stock companies on a "share" or "acre" basis for the growing and setting out of large areas of trees. The enthusiasm for Eucalyptus planting and the statements made during this period were based on the over-enthusiastic estimates of growth referred to above and a general feeling that because of the very rapid cutting of the hardwoods of the Mississippi Valley, Eucalyptus timber would command very large prices within a comparatively short time. The U. S. Forest Service, the California State Forester, and the University of California Agricultural Experiment Station urged the necessity for caution in applying maximum yield figures to plantations growing under untried conditions, on the basis of the very slender fund of experimental data then available. In 1908 and later each of the above mentioned organizations issued one or more bulletins giving conservative figures as soon as these could be compiled. This assisted materially in checking the over-enthusiastic tide of investment and speculation, but did not take effect until a very large total acreage had been planted. In all there 
are probably between forty and fifty thousand acres in California which are, or have been, planted with Eucalyptus. During, and before this period, the U. S. Forest Service and the University of California Agricultural Experiment Station had been carrying on experimental work in Eucalyptus planting; the former in favored localities of the Angeles and Santa Barbara National Forests, and the latter at the

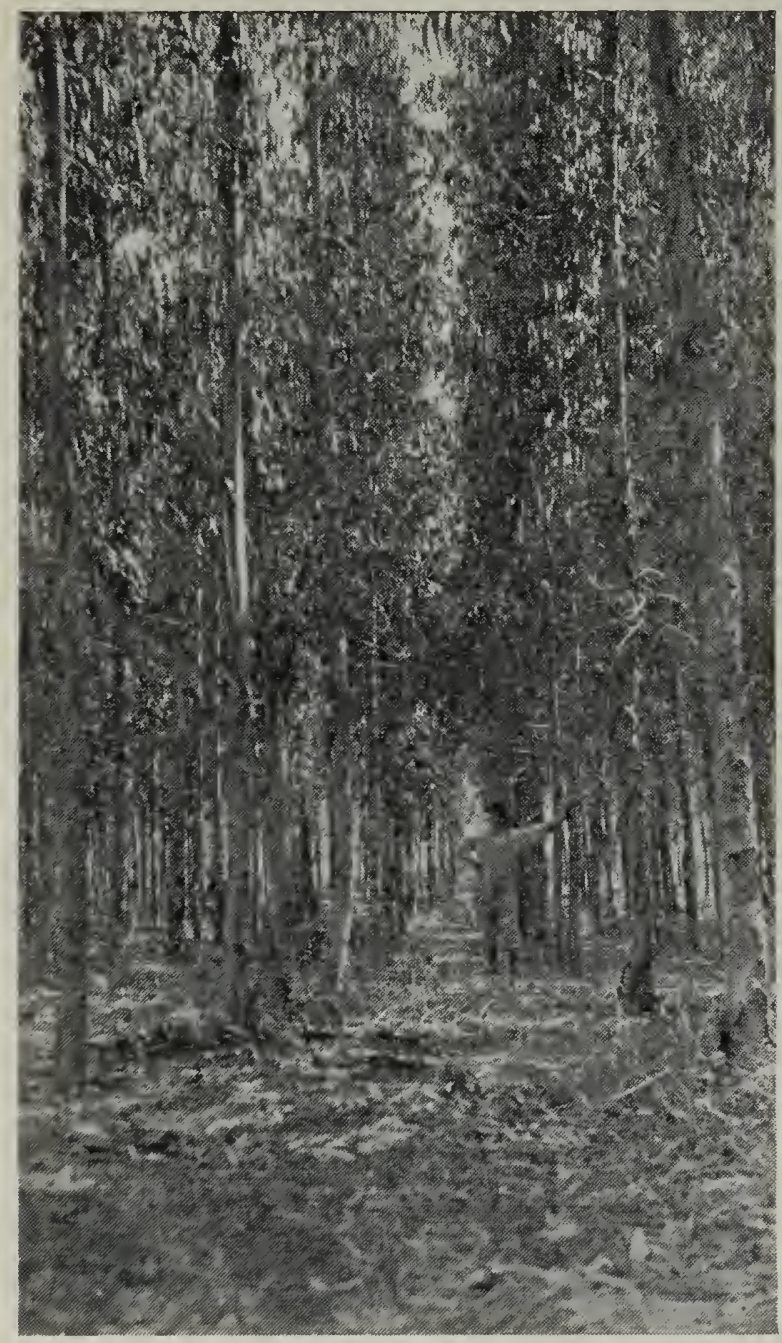

Fig. 3.

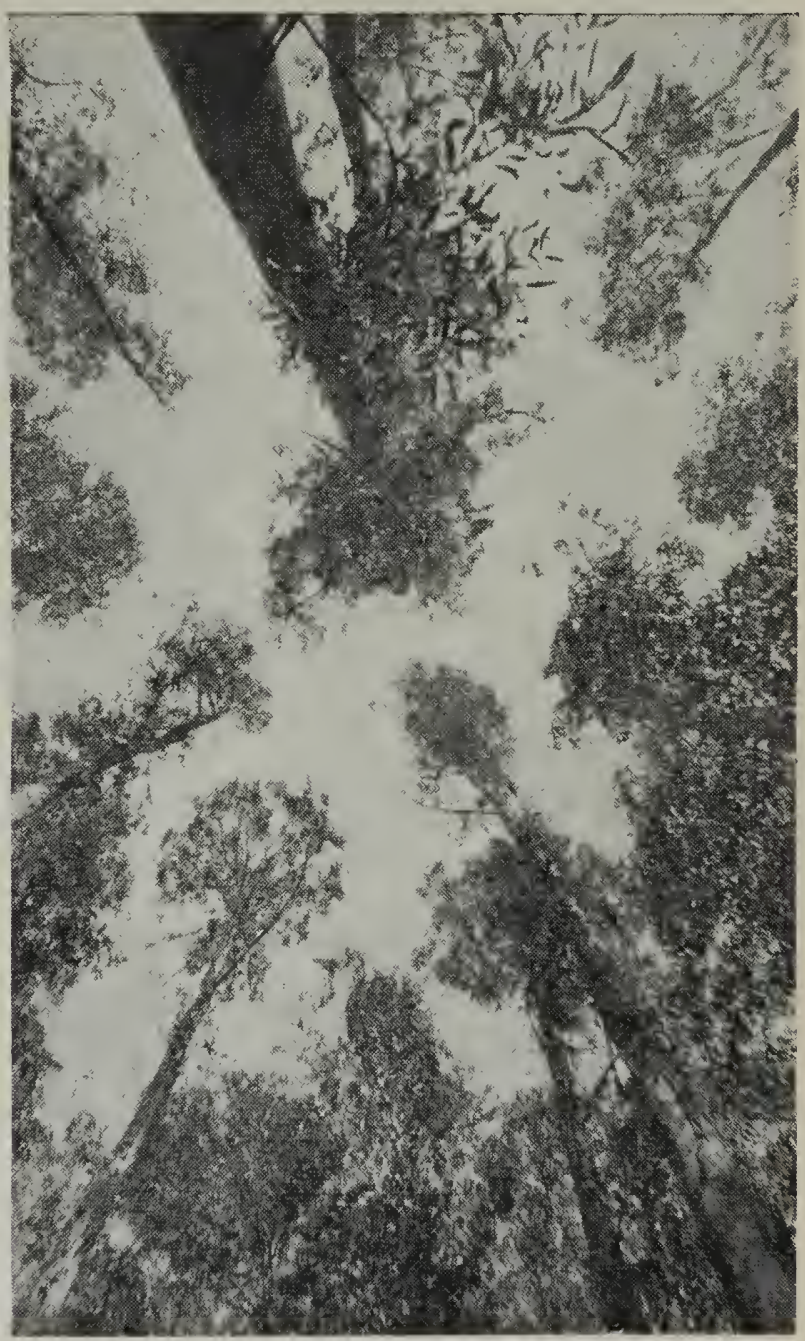

Fig. 4 .

Fig. 3.-Blue Gums, 71/2 years old growing on bottom land near Lakeside, San Diego County. The trees average 4.8 inches d.b.h. and 52 feet in height. Blue Gum in southern California or interior valleys requires adequate amounts of soil moisture for good development. The upland portion of this plantation showed many dead and scrubby trees from lack of moisture.

Fig. 4.-Looling upward through the crowns of 35-year-old Blue Gum trees on bottom land at Berkeley, Alameda County. The spacing here is approximately $7 \times 14$ feet after thinning. Eucalyptus trees have relatively thin crowns and do not make a dense shade.

Chico and Santa Monica Forestry Stations. It soon became apparent, however, that results obtained in these restricted localities would be lacking in applicability to the state as a whole, because not truly representative of the wide range of soil, and climatic conditions, under which Eucalyptus trees were being planted. 
In 1912 officials of the United States Forest Service, realizing the need for more comprehensive experimental data, and recognizing the opportunity offered by the large number of groves which had recently been planted, undertook to make a study of growth in a number of them. Mr. J. A. Mitchell, who was later in charge of the Feather River Experiment Station, began the work on this project that year by taking sample plot measurements in twenty-five representative plantations. In 1916, on request of the Forest Service, the continuation of this study was taken over by the Forestry Division of the University of California; it being recognized that practically all National Forest land is unsuited to the growing of Eucalyptus because of adverse climatic conditions. In May, 1916, Mr. Mitchell and the writer remeasured the sample plots previously established, and selected and measured several others in addition. (For methods used in collecting field data, see appendix I.) Practically all of these first plots were confined to groves of Blue Gum, Eucalyptus globulus, but since that time the study has been extended to include many other species growing under as diversified conditions as could be found. Reference to the accompanying tables will show a considerable number of species represented, but most of them are found in California only as individual trees or single rows or groups in experimental plantings. Practically all of the plantation areas now consist of trees of one or more of the following four species:

Blue Gum, Eucalyptus globulus.

Gray Gum, Eucalyptus tereticornis.

Red Gum, Eucalyptus rostrata.

Sugar Gum, Eucalyptus corynocalyx (cladocalyx)

The approximate percentage of each of these species to the total area in plantations is roughly estimated as follows: Blue Gum, 80\%, principally in the coast region but also present in other sections; Red and Gray Gums 15\%, chiefly in the Sacramento and San Joaquin valleys and the interior valleys of southern California; Sugar Gum $4 \%$, mostly confined to southern California because it is not frost hardy; other species $1 \%$.

\section{Blue Gum (Eucalyptus globulus)}

The blue Gum is widely distributed throughout Tasmania and Victoria on the lower slopes of the hills, but is usually not found in pure stands. Scattered individuals also occur in the southern mountain sections of New South Wales. In its native habitat it grows rapidly and reaches great size (250 feet in height). Practically all 
of the timber cut in Australia is virgin growth, probably several hundred years old. Small differences are noted by Dr. J. H. Maiden and other writers on Australian trees, between the Tasmanian and Victorian trees of this species.* The wood cut from Australian trees is used somewhat for wagon stock, and other heavy work but as it is difficult to dry and very subject to warping and checking, it is not used for building and is not thought much of for timber.

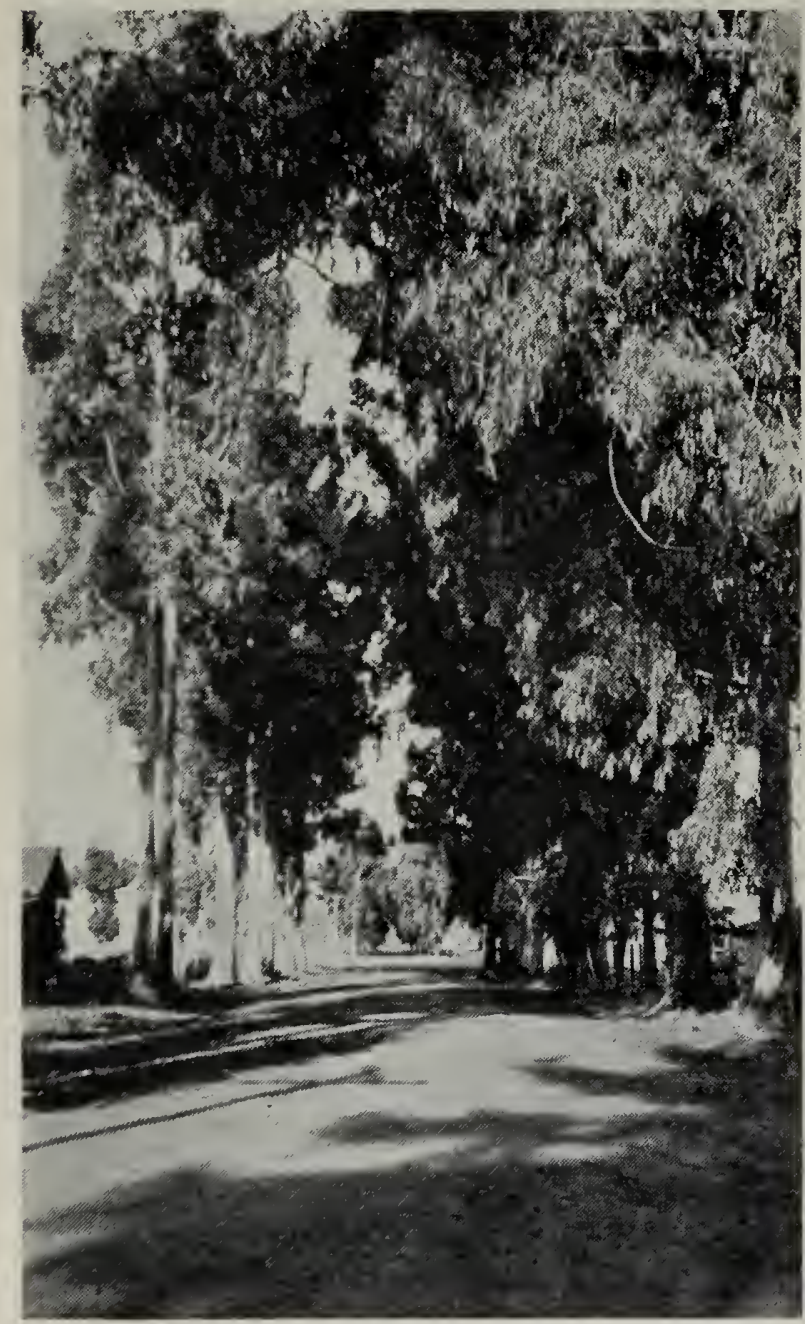

Fig. 5 .

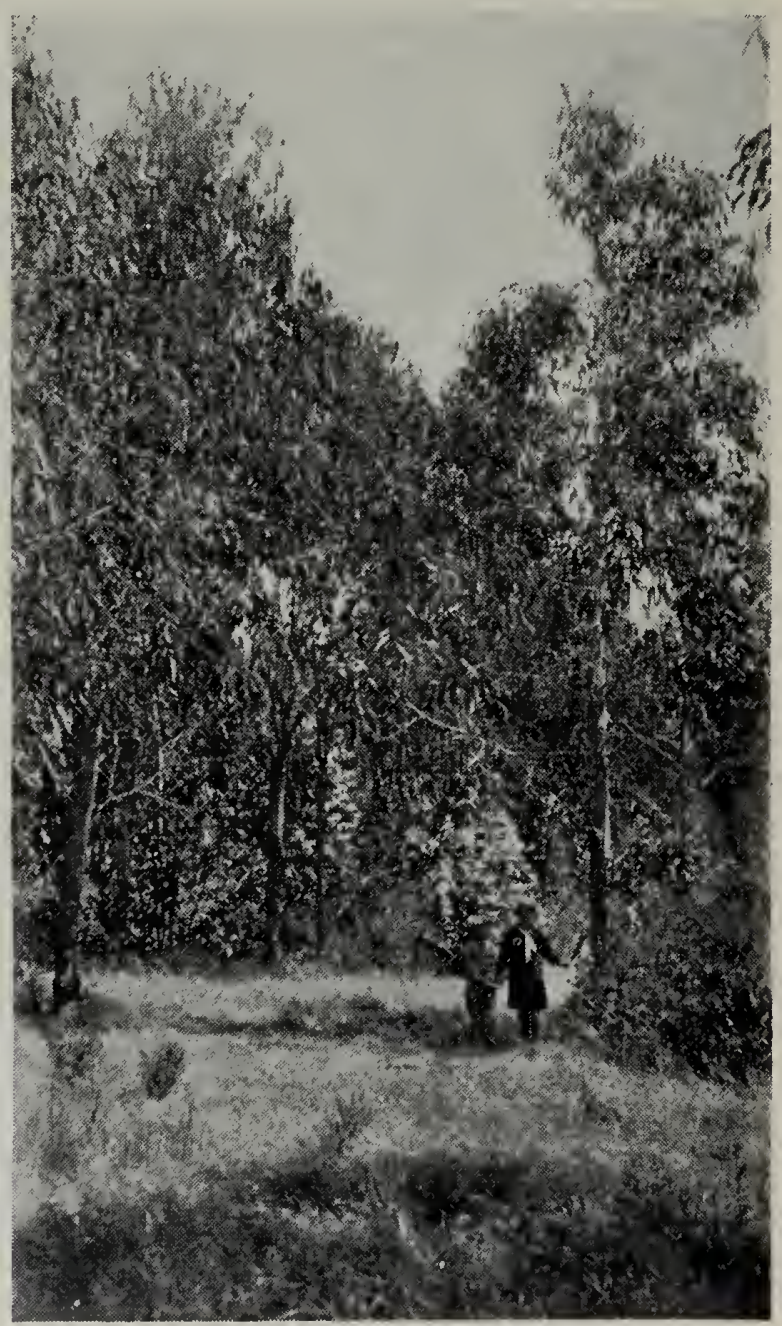

Fig. 6.

Fig. 5.-These stately Blue Gum trees at Newark, Alameda County, are 40 years old. The species is one of the finest for highway and windbreak planting in California valleys.

Fig. 6.-This view in a 10-year-old plantation of Blue Gum on sand dune soil near Monterey, illustrates the large number of fail places and the encroachment of grass and brush into the plantation. On poor, dry soil, Blue Gum assumes a spreading, stunted form even in the coast counties where climatic conditions are suitable.

In the settled portions of California, the Blue Gum is now one of the most conspicuous features of the landscape, being found almost everywhere in groves, windbreaks, along highways or in lawns and parks (fig. 5). In fact, it is so common everywhere that it typifies

* See page 42. 
California to a host of people who are unfamiliar with the Redwood, Sugar Pine, or others of her splendid native forest trees.

The Blue Gum may easily be distinguished from all other species of Eucalyptus by its smooth olive-green trunks from which the bark is shed annually in long shred-like vertical strips; its bright blue juvenile foliage with the leaves borne opposite in pairs on twigs which are often fluted so as to appear four-angled in cross section; and its bright bluish, warty, four-angled buds which after shedding the flat-conical caps, develop into large yellowish white flowers. These appear on the trees in great profusion and are an important source of honey. The mature leaves are alternate in arrangement, very coarse in texture, and are borne on dark reddish twigs from which they hang suspended like miniature sickles. The flat topped, button-like fruits are about three-quarters of an inch in diameter and bear tiny shiny black seeds, smaller than the head of a common pin. Flowers and fruits are sometimes borne on sprouts only two or three years old, and the ripened fruits can usually be found in great quantities under trees of ten years or more in age. The Blue Gum is usually an erect tree with a single stem which often shows a corkscrew-like tendency to twist in its upward growth. Where seedlings have been injured by frost, rodents, or light ground fires, two or more stems may develop. The proportion of such trees is shown in column 7 of table 1 as an index of such unfavorable influences.

Table 1 gives a summary of the measurements in sixty-seven representative groves of Blue Gum distributed from Humboldt to San Diego counties and representing a wide variety of soil conditions. The position of each grove in a given county is fixed by reference to the nearest town and a brief statement of soil conditions is given in the final column. The present number of trees per acre can be determined from columns 5, 6 and 7, while the diameter, height and volume of the average single tree in each grove is given in columns 8, 9 and 10. The volumes per acre, both total and mean annual, are given both in solid cubic feet and in cords, both figures including bark. The converting factor (90 cu. ft. $=1$ cord) was carefully checked and found to be substantially correct for trees of moderate size including a 10 per cent allowance for shrinkage in drying of the wood after piling.

A careful study of Table 1 brings out many interesting facts. Those groves which have greatly exceeded the mean annual growth of approximately three cords per acre, are found growing on lands of good quality but rather open texture, where the soil moisture is adequate. The best growth seems to have been made in groves where at least a $71 / 2$ by $71 / 2$ foot spacing was used (fig. 1 ). The results of overcrowding 


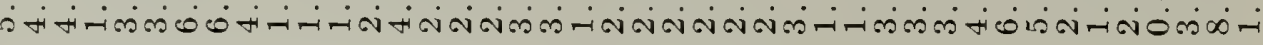

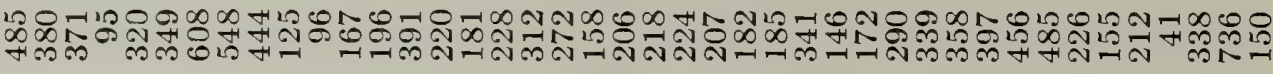

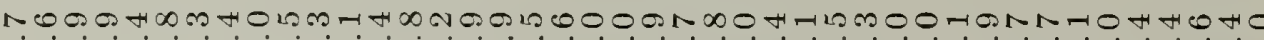

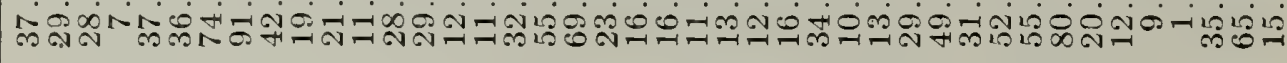

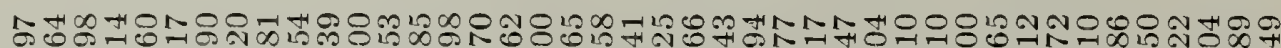

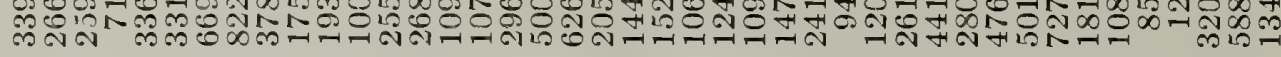

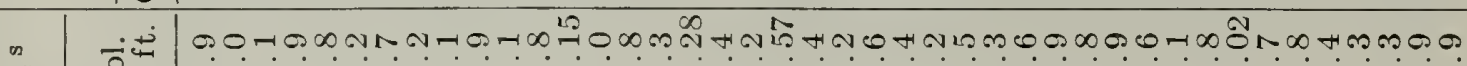

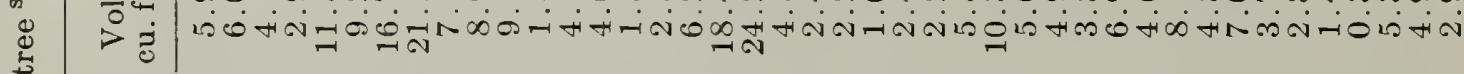

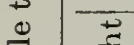

要

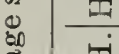

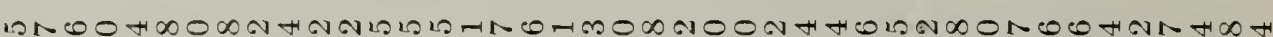

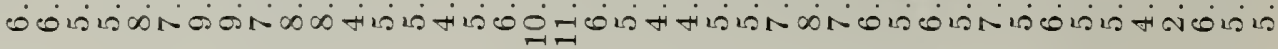

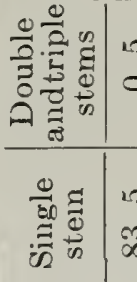

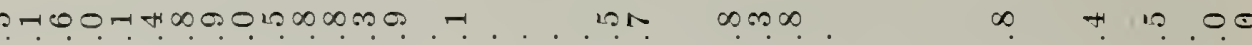

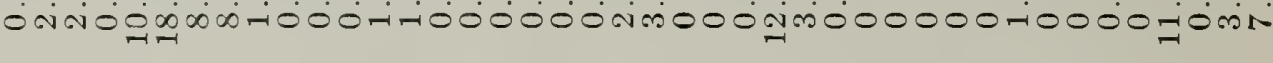

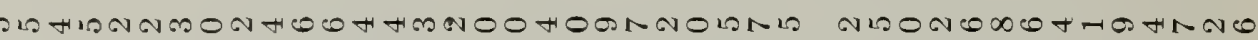

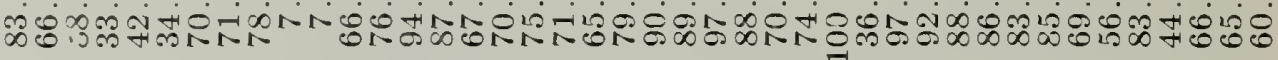

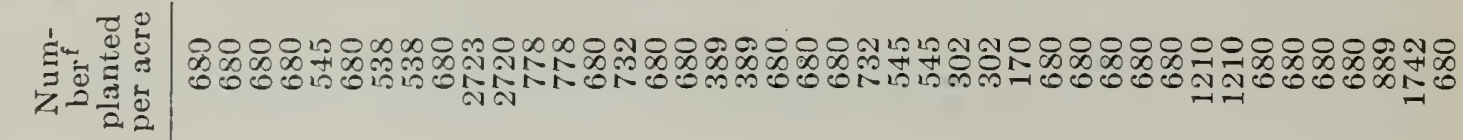

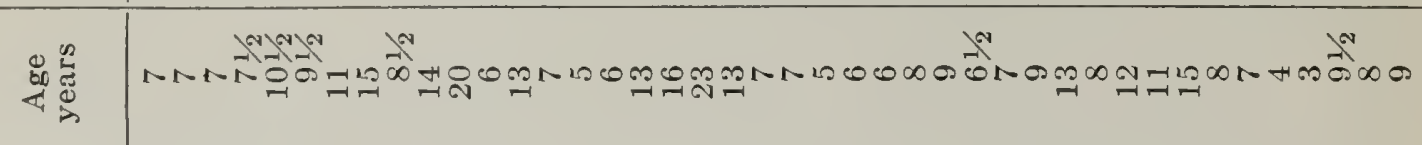

$\vdots \vdots$

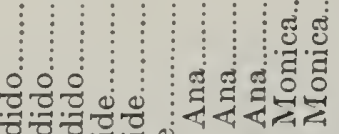

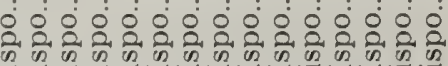

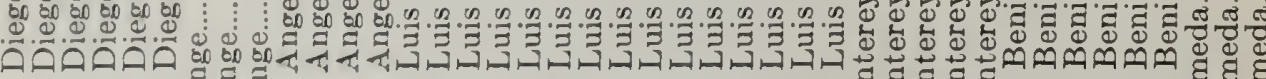

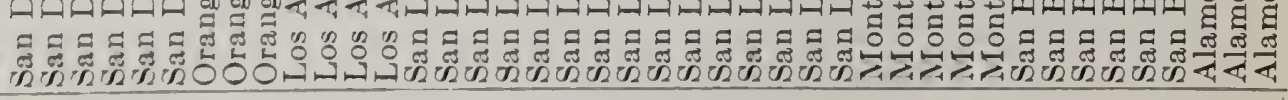
范 | | | 


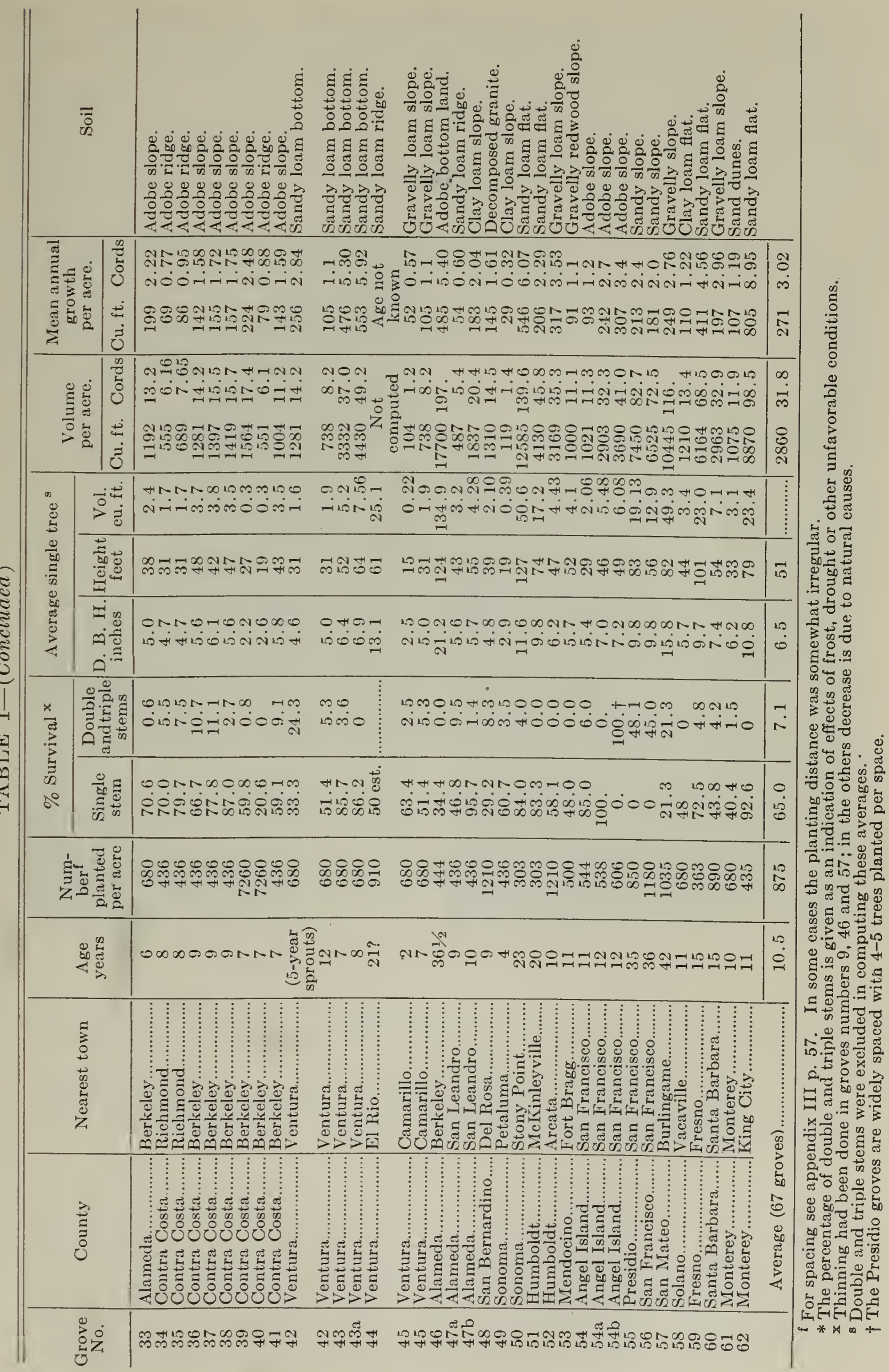


are shown in groves Nos. 9, 39 and 40, while the growth in No. 31 was made in spite of a 5 by 5 spacing because of the rich silt soil, and a superabundance of soil moisture. In every case where the mean annual growth approaches or exceeds 5 cords per acre, the land is of good agricultural value and the water table close enough to the surface to insure an almost continuous supply. The growth on sandy

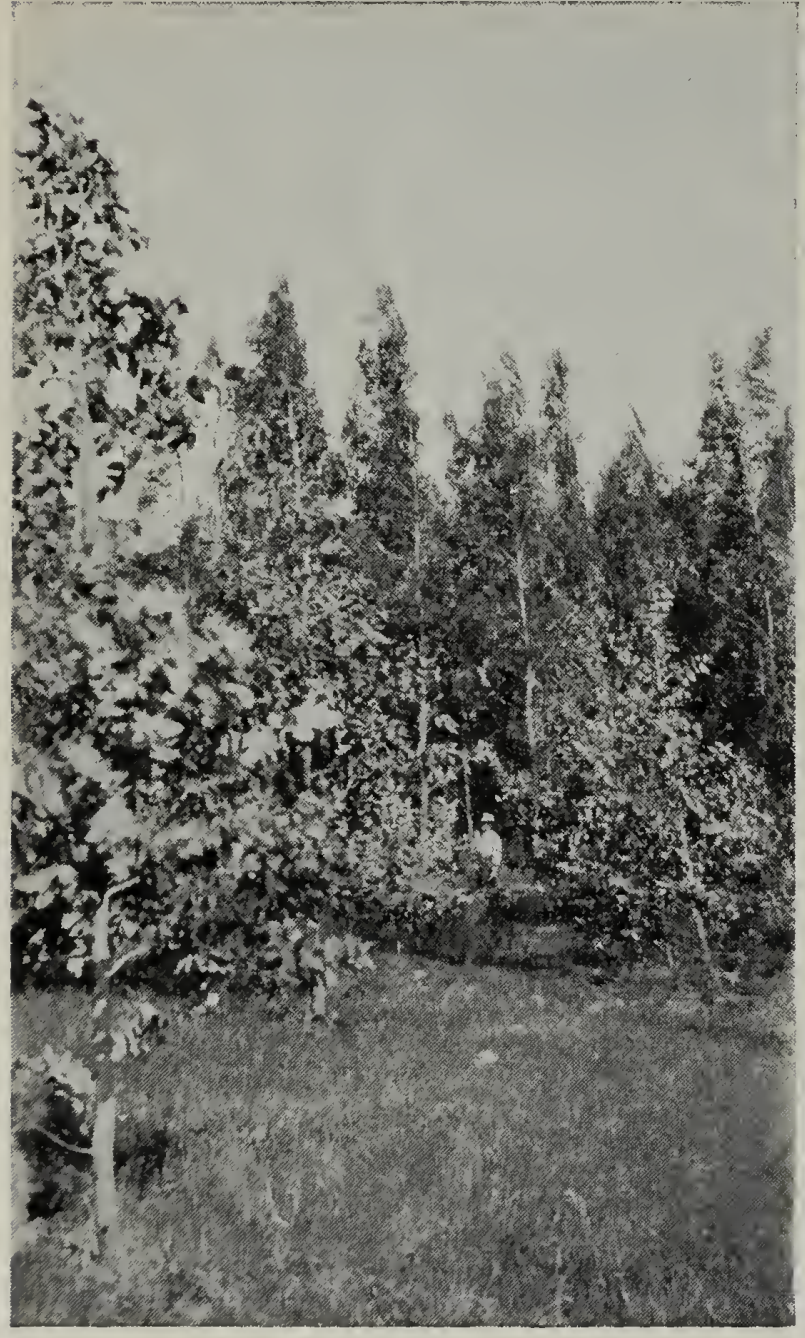

Fig. 7.

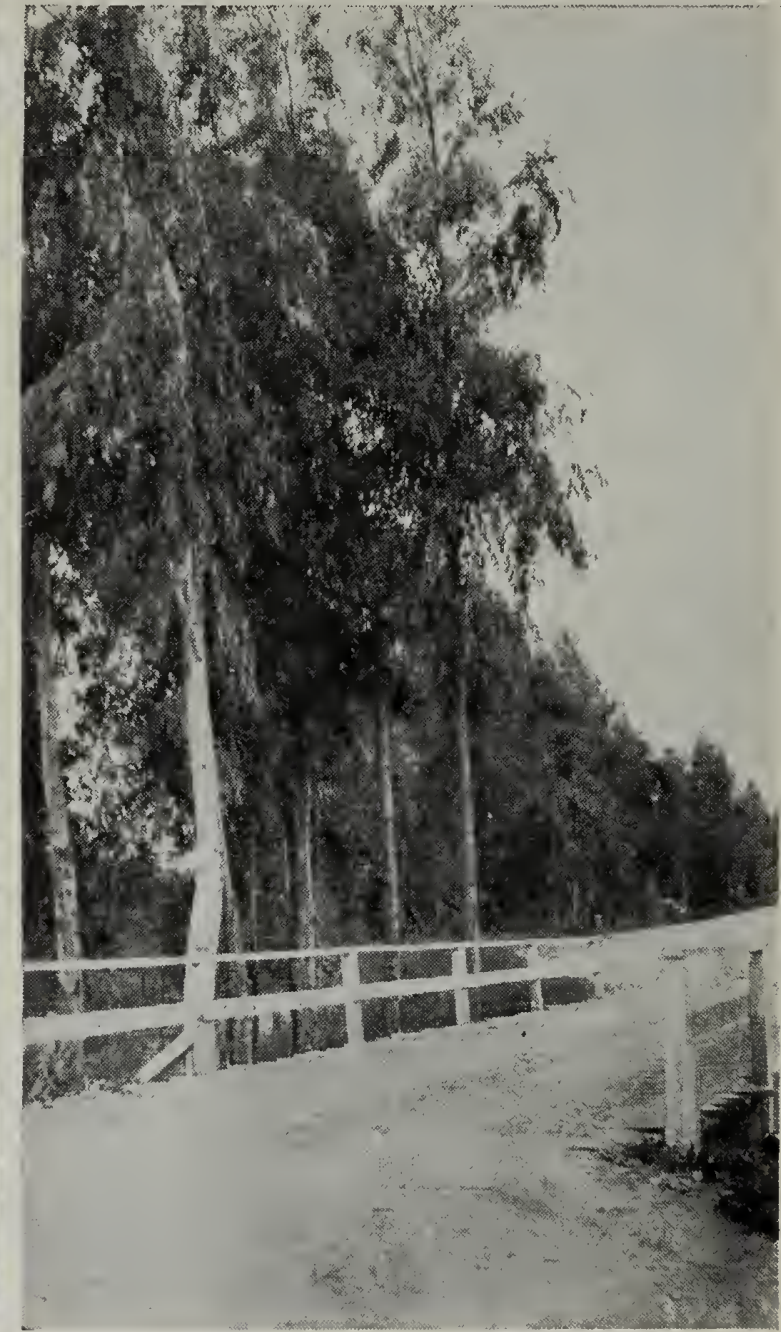

Fig. 8.

Fig. 7.-This grove near Chittenden, San Benito County, shows Blue Gums three and four years old. Both ages were seriously affected by the dry summers of 1916 and 1917. During years of excessive drought, the establishment of plantations is difficult.

Fig. 8.-Blue Gums used to prevent the washing of arroyo banks near East Whittier, Los Angeles County. While stopping erosion, they are growing rapidly into valuable fuel wood.

mesa lands of poor quality is well indicated by groves Nos. 11-21, inclusive (figs. 2 and 6), where the mean annual growth exceeded four cords per acre in only one grove. Likewise slow mean annual growth is recorded in groves Nos. 31-41 on the shallow, gravelly adobe slopes of the Berkeley and Livermore hills. The influence of competition by redwood sprout growth is shown in No. 53 (fig. 9). The abnormally 
high rate of growth in the King City grove No. 62 resulted from a mixed planting in which the Blue Gum far outstripped the other species in rapidity of growth and had unusual space for development. What are probably the two finest groves of this species in the state are both in Alameda County; one on the University of California campus at Berkeley (No. 46, see frontispiece and fig. 4), the other on the Patterson Ranch near Arden. Both of these groves are growing on bottomland soil of good quality, and have been thinned at intervals so as to give the best trees room for individual development. The Patterson grove was not included in the table as it was impossible to secure exact information as to its age. It is of great interest, however as an example of mixed planting. The Eucalyptus trees were spaced 24 by 24 feet, the intervening spaces at 8 -foot intervals being occupied temporarily by Lombardy poplars. This species in spite of its rapid growth was able to persist in the stand for only about 15 to 20 years, after which the trees were quickly overtopped and killed out by the Eucalyptus. The resulting stand of Blue Gum is exceptionally fine because of the large size and perfect development of the individual trees.

Ten of the sixty-seven groves have been measured twice and in each case the remeasurement figures are given in Table 1 on the line following the original measurement figures. This makes it possible to compare the two sets of figures directly in order to give an indication of the periodic growth. It will be noted that in one or two cases the average diameter or height at the time of the second measurement is less than the previous one by a slight amount. This is explained by the death or removal of several of the larger trees from the measured rows.

For method of taking field measurements see appendix I. A Yield Table for Blue Gum.

On the basis of the measurements of the 67 groves shown in Table 1 it has seemed desirable to derive a tentative yield table which will give the approximate volume production of Blue Gum plantations at different ages on sites of good, medium and poor quality. The data were arranged according to the height method (see appendix II for details) and the final yield figures are given in Table 2.

All of the groves classified as Site I are growing on deep bottomland soil of good agricultural quality, with the water table near the surface of the ground for a considerable part of each year. Such sites should therefore be considered of too high quality to be used for growing Eucalyptus trees and eventually all groves on this type of land will be cleared and devoted to the growing of agricultural crops. 
An example may be cited in the case of the C. B. Turton grove in Orange County (No. 7) which, although making very rapid growth, is being clear cut in 1923 in order that the land may be devoted to the raising of walnuts. Adjacent land in bearing walnut trees is said to be worth about $\$ 1,000$ per acre.

TABLE 2

Yield of Eucalyptus Globulus on Different Sites

\begin{tabular}{c|r|r|r}
\hline \hline \multirow{2}{*}{ Age, years } & \multicolumn{2}{|c}{ Volume in solid cubic feet, including bark } \\
\cline { 2 - 4 } & Site I & Site II & Site III \\
\hline 2 & 300 & 100 & 0 \\
4 & 1,050 & 600 & 250 \\
6 & 2,150 & 1,350 & 750 \\
8 & 4,400 & 2,400 & 1,400 \\
10 & 6,100 & 3,400 & 2,050 \\
12 & 7,450 & 4,350 & 2,550 \\
14 & 8,550 & 5,150 & 2,900 \\
16 & 9,600 & 5,900 & 3,250 \\
18 & 10,500 & 6,500 & 3,500 \\
20 & 11,450 & 7,100 & 3,800 \\
\hline
\end{tabular}

To convert to standard cords $\left(4^{\prime} \times 4^{\prime} \times 8^{\prime}\right)$ divide above figures by 90 .

The growth in plantations classified as Site II is slower than in those of Site I because of poor soil, as in the case of the Los Berros Mesa groves in San Luis Obispo County; deficient moisture, as in the case of groves in inland valleys; or other unfavorable factors. Many of these soils would grow fair to good agricultural crops under irrigation, and where water can be developed as in the Santa Fe Railway plantation area in San Diego County, the Eucalypts are forced to give way to more valuable crops.

The Site III groves are usually on land too steep, too infertile, too arid, or exposed to too severe winds to be valuable for agriculture. These and the Site II groves on which irrigation is not feasible, are probably the only sites which will be permanently devoted to growing Eucalyptus trees. At some time in the future it may be desirable to draw up a new yield table from which all strictly agricultural areas will be omitted, but it is felt that the above figures are adequate for the present and the immediate future. Planting of Eucalyptus will undoubtedly be continued and extended on many strictly agricultural soils to utilize small, odd-shaped corners of the ranch; steep creek banks or other slopes; (fig. 8) or in long narrow shelterbelts which will furnish protection from hot, drying winds. The Site I figures given above will be a good index of the volume growth possible under such conditions. 


\section{Red Gum (Eucalyptus rostrata)}

Next to Blue Gum the Red Gum (Eucalyptus rostrata) has been used most extensively in California plantations. It is somewhat more frost resistant than the Blue Gum and has generally been used on sites believed to be too cold for the latter. It is also able to withstand

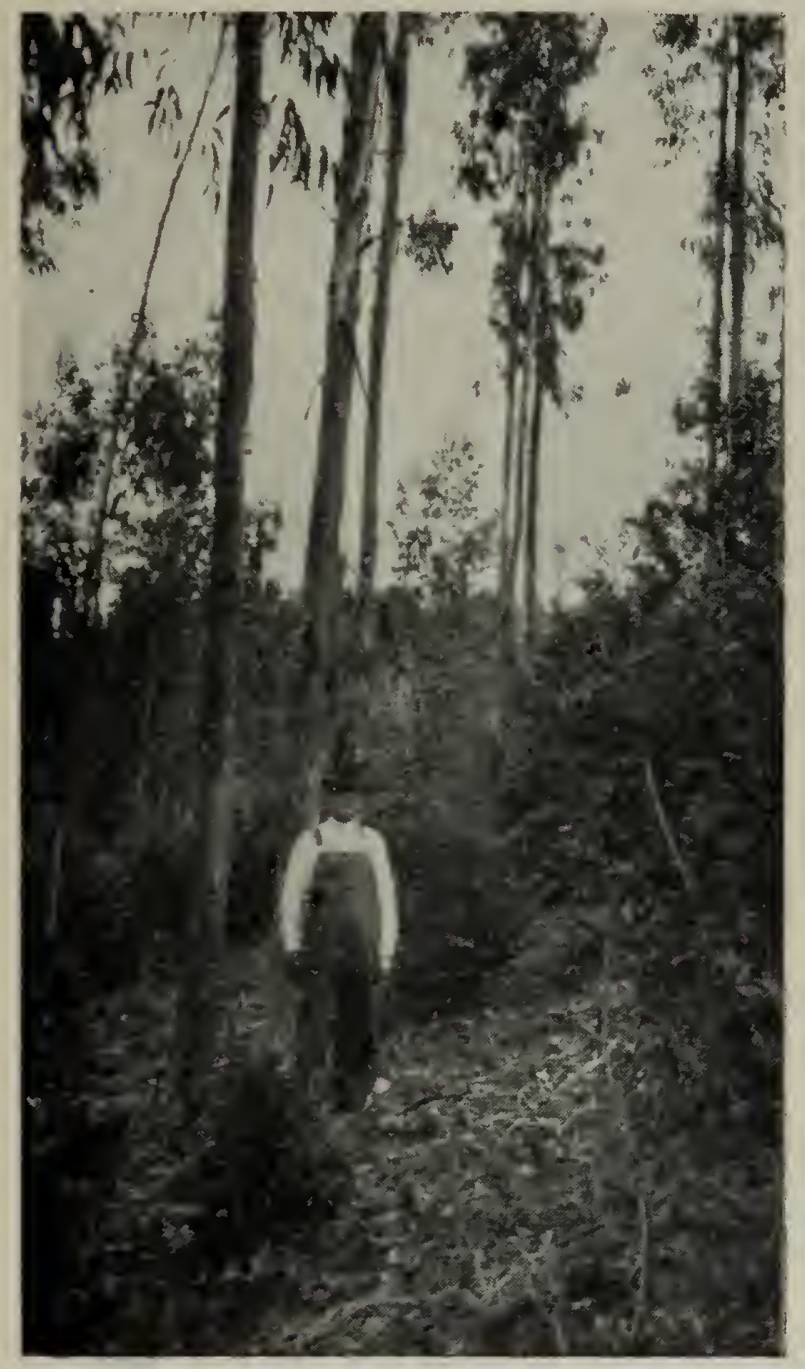

Fig. 9.

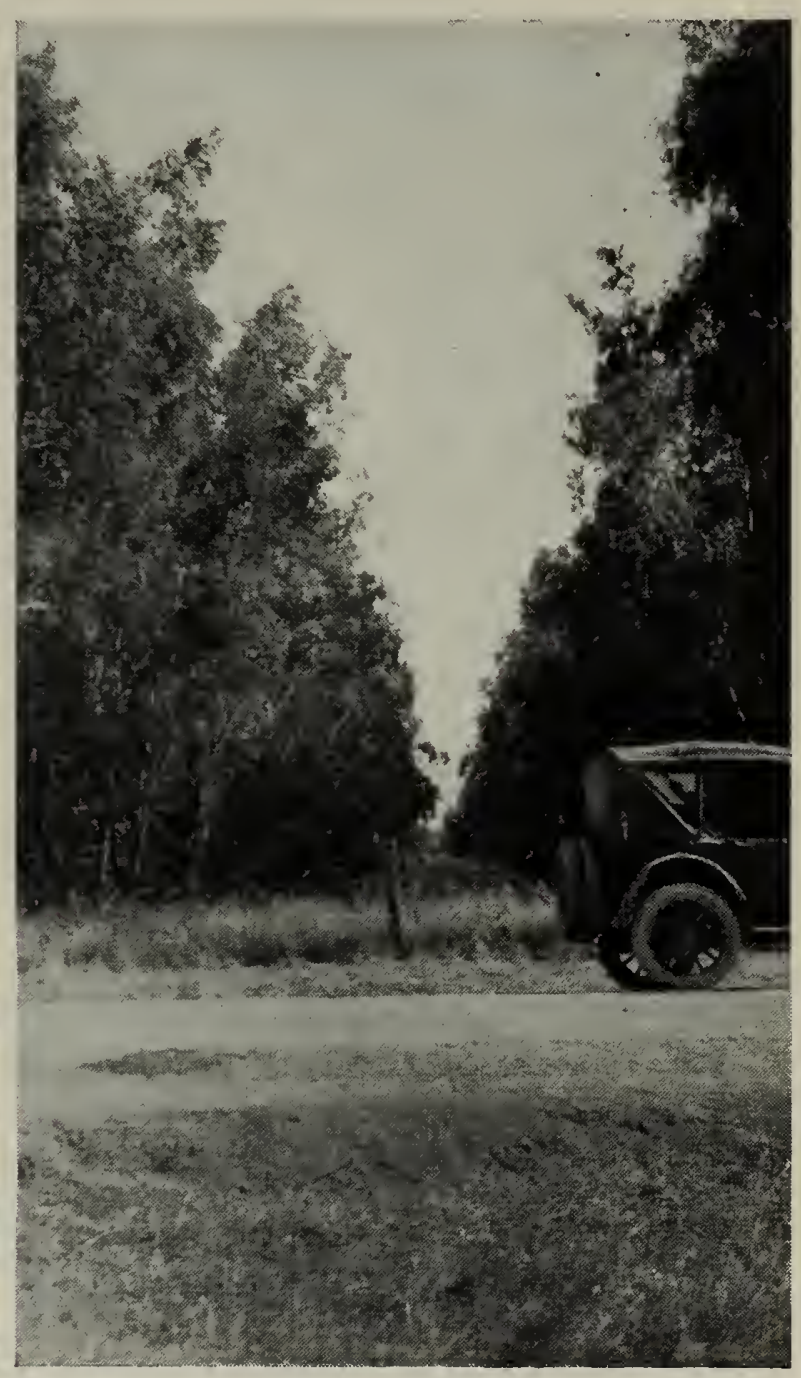

Fig. 10.

Fig. 9.-Blue Gum plantation on cut-over Redwood land along the Noyo River, Mendocino County. At 10 years of age there are 340 surviving trees per acre of which 34 per cent are small, stunted scrubs. The others average 5.1 inches d.b.h. and 52 feet in height, but the crown cover is so thin that they have had no effect on Redwood sprout reproduction.

Fig. 10.-Red Gum plantation 11 years old on good sandy loam soil near Dunnigan, Yolo County. The crooked habit of growth of this species is well shown.

more severe drought and alkali conditions than the Blue Gum but in some places has been a practical failure where these two factors were excessively severe. The typical Red Gum under California conditions has leaves which are narrower and of finer texture than those of Blue Gum. They are borne in gracefully drooping sprays of foliage; the 


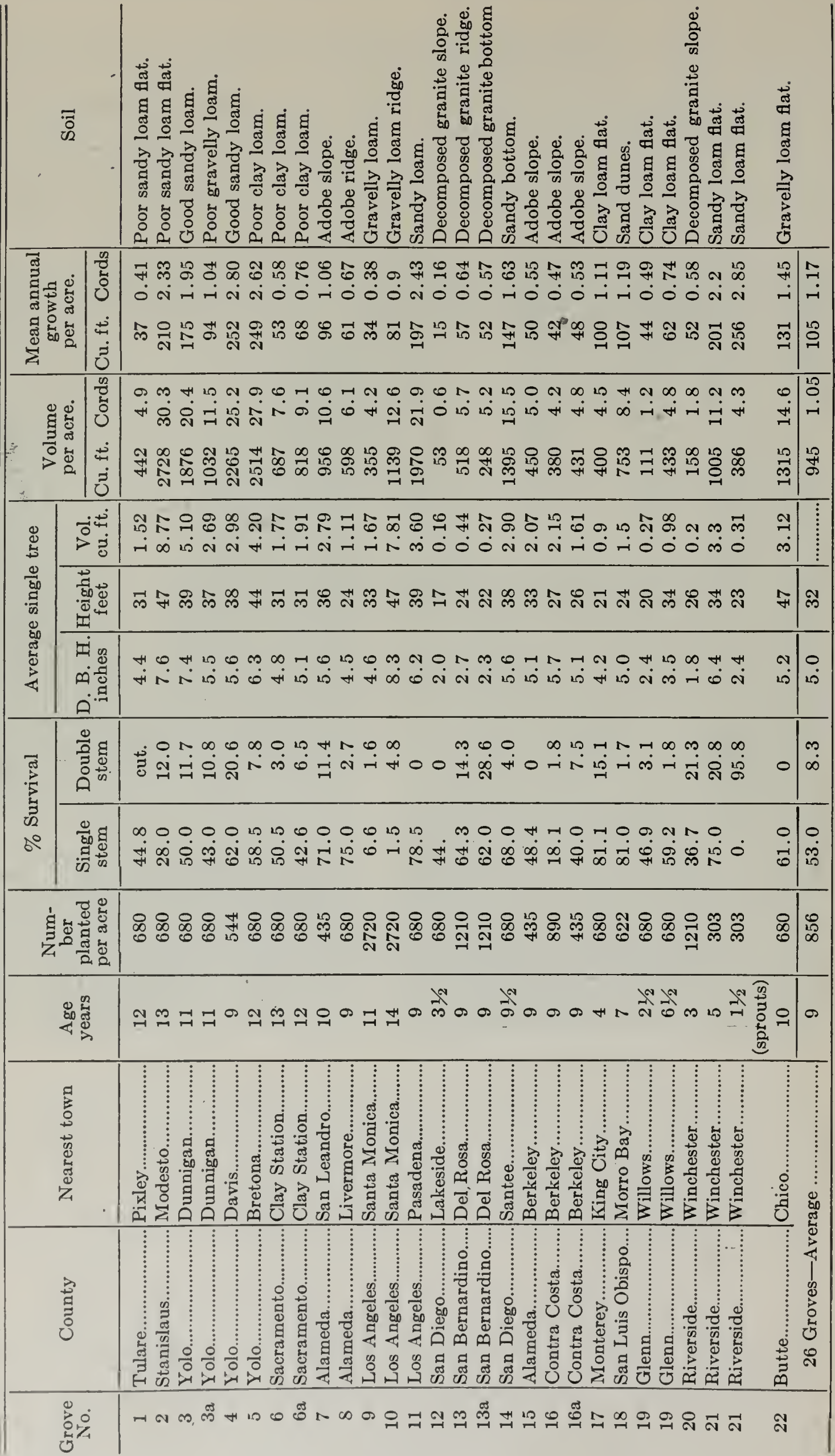


slender twigs being bright red. The flowers and fruits are less than one-fifth the size of those of the Blue Gum, are prominently stalked and borne in umbel-like clusters of seven or more flowers to the cluster. The flowers are borne in great profusion and are white or cream colored. The buds are sharply pointed, and the caps which fall before the flowers open are like tiny cornucopias, about 1/8 inch across the open end. The fruits when ripe are almost globular in shape, about $3 / 16$ inch in diameter and look like clusters of small greenish brown shoe buttons. The Red Gum and the following species, the Gray Gum, are very similar in all of the above characteristics, and even in Australia it is often difficult to tell the trees apart. Under these conditions it is inevitable that there should have been some mixing in seed collecting and varying percentages of both species are undoubtedly present in groves planted for either. The Red Gum under California conditions is almost invariably very crooked in its habit of growth, a large percentage of trees have forked tops which gives them a somewhat stunted appearance even when they have attained considerable size. These characteristics, together with the smooth, generally unmottled bark, red twigs and drooping sprays of foliage may be used to distinguish this species.

In Australia the Red Gum (preferably called River Red Gum or Murray River Gum) is a large wide spreading tree with a short, crooked trunk; somewhat like an apple tree in general appearance, but much larger and having a beautiful dome-shaped crown. It has a very wide range, occurring in all of the states except Tasmania but reaching its best development on the open bottomlands of the Murray River and its tributaries between Victoria and New South Wales. Here well grown mature trees are often 100 feet high, but it is not considered a suitable tree for timber on account of its poor form (fig. 10). The wood is a beautiful pinkish red color, very hard with a much twisted and interlocked grain which makes it difficult to season, but is very durable in the soil. The wood is highly valued for heavy wagon wheel felloes and similar purposes, also for railway ties and underground portions of buildings. Although quite ornamental it is rarely used for furniture because of its hardness and the twisted grain.

It will be noted from Table 3 that the rapidity of growth of Red Gum is less than half that of Blue Gum. This might be expected where the tree has been planted under colder drier conditions, but it also holds true where the two species are growing in adjacent plantations. The Red Gum is not well suited to the conditions obtaining along the coast where the Blue Gum is at its best, but has made its best growth in the interior valley sections (Yolo and Stanislaus counties) and in 
southern California. Because of its ability to withstand drought and alkali this tree has often been planted under such severe conditions that it had very little chance to make satisfactory growth. Hard pan near the surface, as at Clay Station, Sacramento County, or excessive amounts of alkali, as in the groves at Pixley, Tulare County, have resulted in high percentage of failure in the plantations and scrubby form of trees.

On the basis of the above measurements, no attempt has been made to classify the groves of this species according to site quality or to develop even a preliminary yield table. It will be noted that the mean annual growth of even the best Red Gum groves averages only about two cords per acre, and the maximum growth recorded, 2.8 cords per acre per year, was made in a small grove on the University Farm at Davis where soil conditions are optimum and the trees had good irrigation at intervals as a sewage reservoir is located within the plantation. In Australia the River Red Gum is not a dry land tree, but reaches its best development in open stands,on bottomland flats where it is subject to frequent flooding. A grove near the Yolo Causeway between Davis and Sacramento has been subject to winter flooding on several occasions, but other conditions on that site have not been good enough to make the grove even a moderate success. Several groves of this species have been planted in the Imperial Valley where they have persisted under the extreme heat conditions only because the plantations have been flooded at about monthly intervals during the dry season.

\section{Gray Gum (Eucalyptus tereticornis)}

The Gray Gum or Forest Red Gum as it is called in Australia, is so closely related to the Red Gum as to be considered by many authorities as a variety of that species. Extreme forms may be easily recognized from the Red Gum by the mottled bark, broad leaves, heavier fruits and the generally erect habit of growth; but in many cases it is practically impossible to tell which of the two trees predominates in a given stand. The erect habit of growth has been taken as the most reliable indication of Gray Gum although the other factors were also used where possible.

The Gray Gum is evidently more susceptible to frost than either the Blue or Red Gums, but it seems to stand heat and drought better than any of the more commonly planted species (figs. 11 and 13). This is well demonstrated in the plantations near Lakeside, San Diego County, where groves of the four species are growing in closely adjacent blocks on decomposed granite soil of very open texture. The low annual 
rainfall, high summer temperatures, and coarse textured soil combine to make the site one of extreme drought. All four species show the effects of these conditions but the Gray Gum looks more thrifty and shows a higher percentage of survival than the others. Sugar Gum is next in order of thrift on this site, followed by Red and Blue Gums.

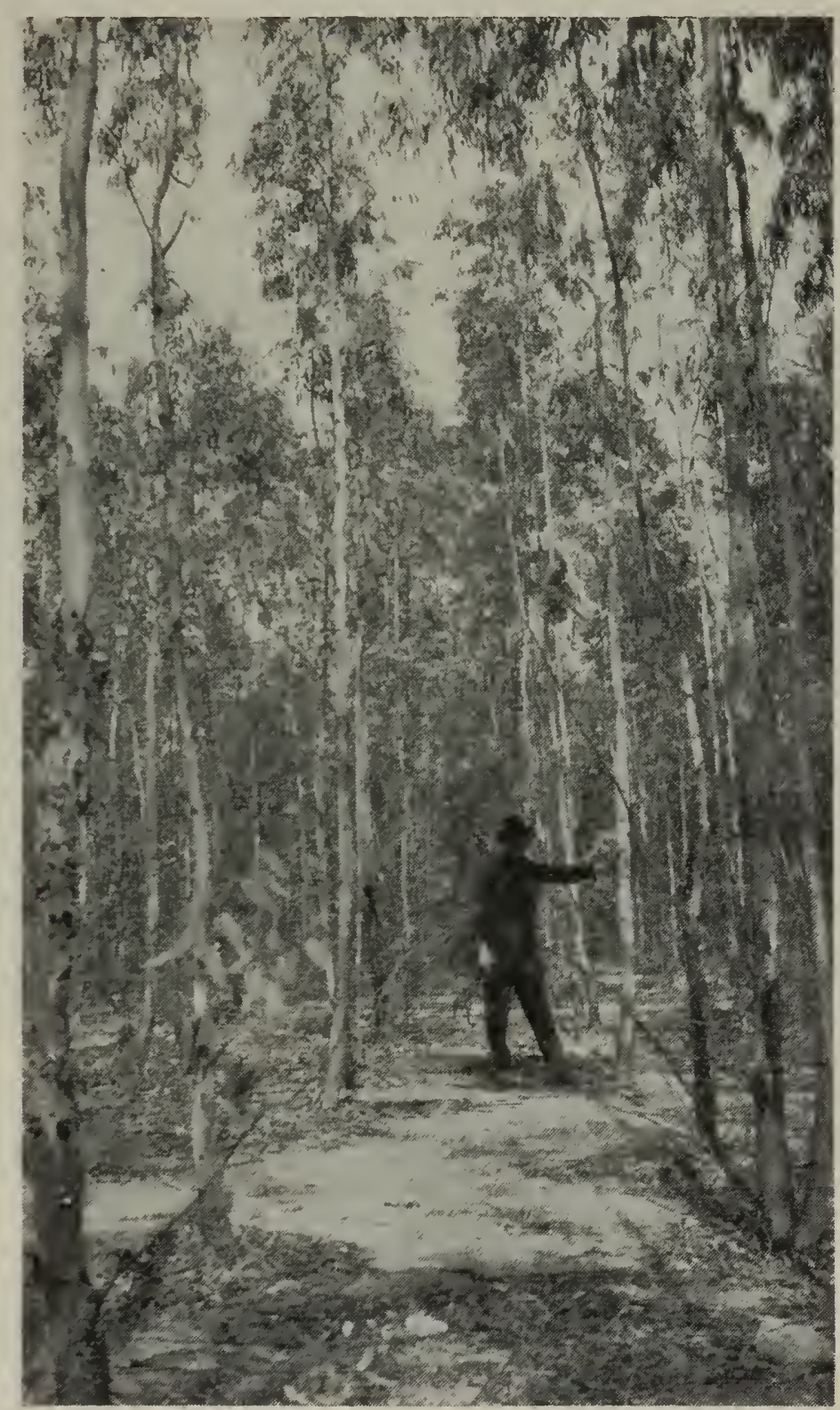

Fig. 11.-Trees in a 9-year-old plantation of Gray Gum growing on decomposed granite foothill land near Del Rosa, San Bernardino County. This species shows up well under the extremely dry conditions of this site.

The last species is unable to persist here except in the gully bottoms where the supply of soil moisture is higher than on the slopes or ridges (fig. 3 ).

In Australia the Forest Red Gum is not as widely distributed as Eucalyptus rostrata. It reaches 150 feet in height, has a much better form and its wood, though similar to rostrata, is preferred because straight grained. 


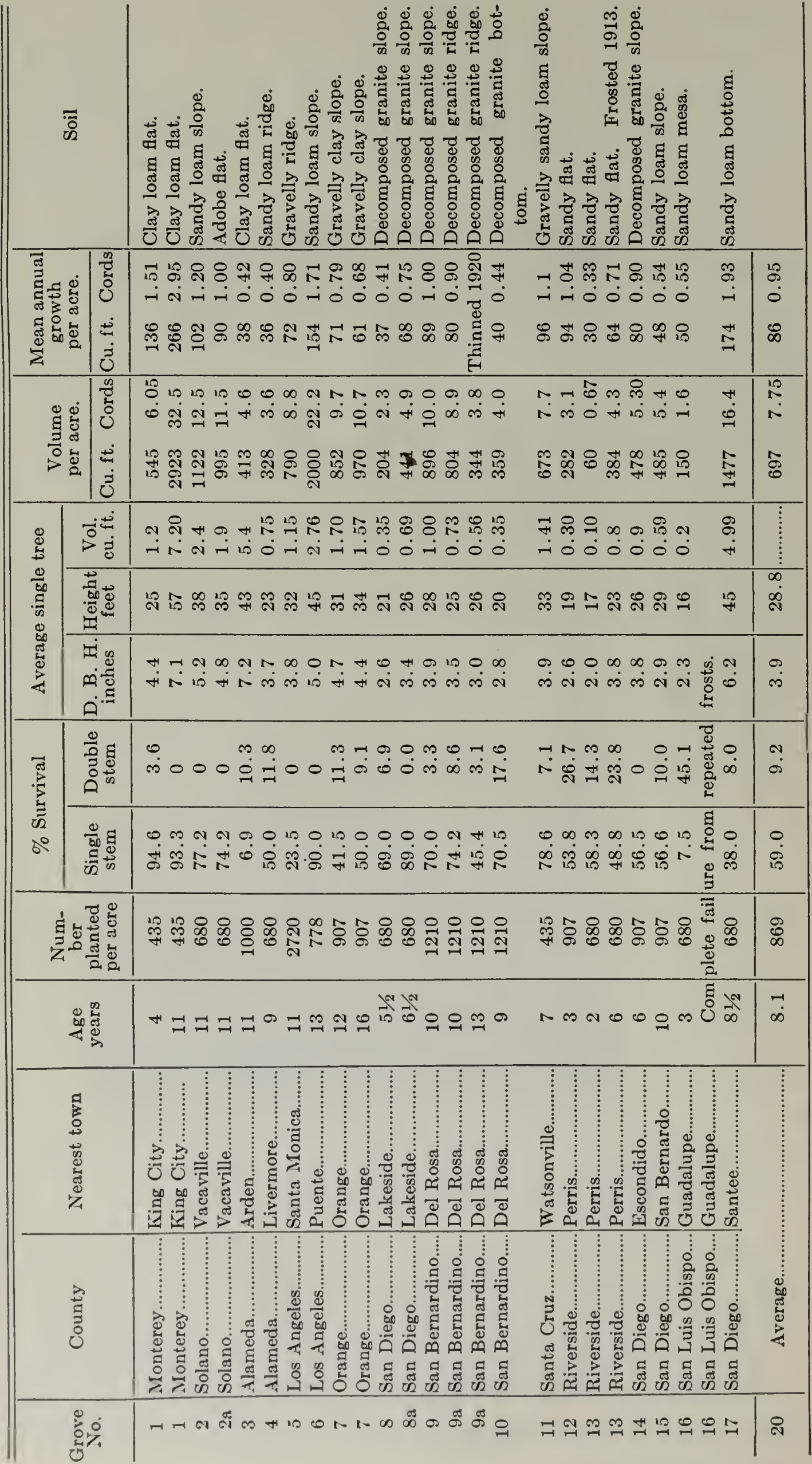


The results of measurements of twenty groves of Gray Gum are summarized in Table 4, in which it will be noted that the mean annual growth of this species rarely exceeds $1 \frac{1}{2}$ cords per acre, and the average is less than one cord per acre per year. Groves numbered 6 and 17 in which maximum growth of 1.71 and 1.93 cords per acre per year were recorded, are both growing on sandy loam soil of excellent quality with better than average soil moisture conditions. Groves 2 and $2 a$ in Solano County (fig. 12) have had exceedingly good care including adequate early cultivation and recent thinning to remove the

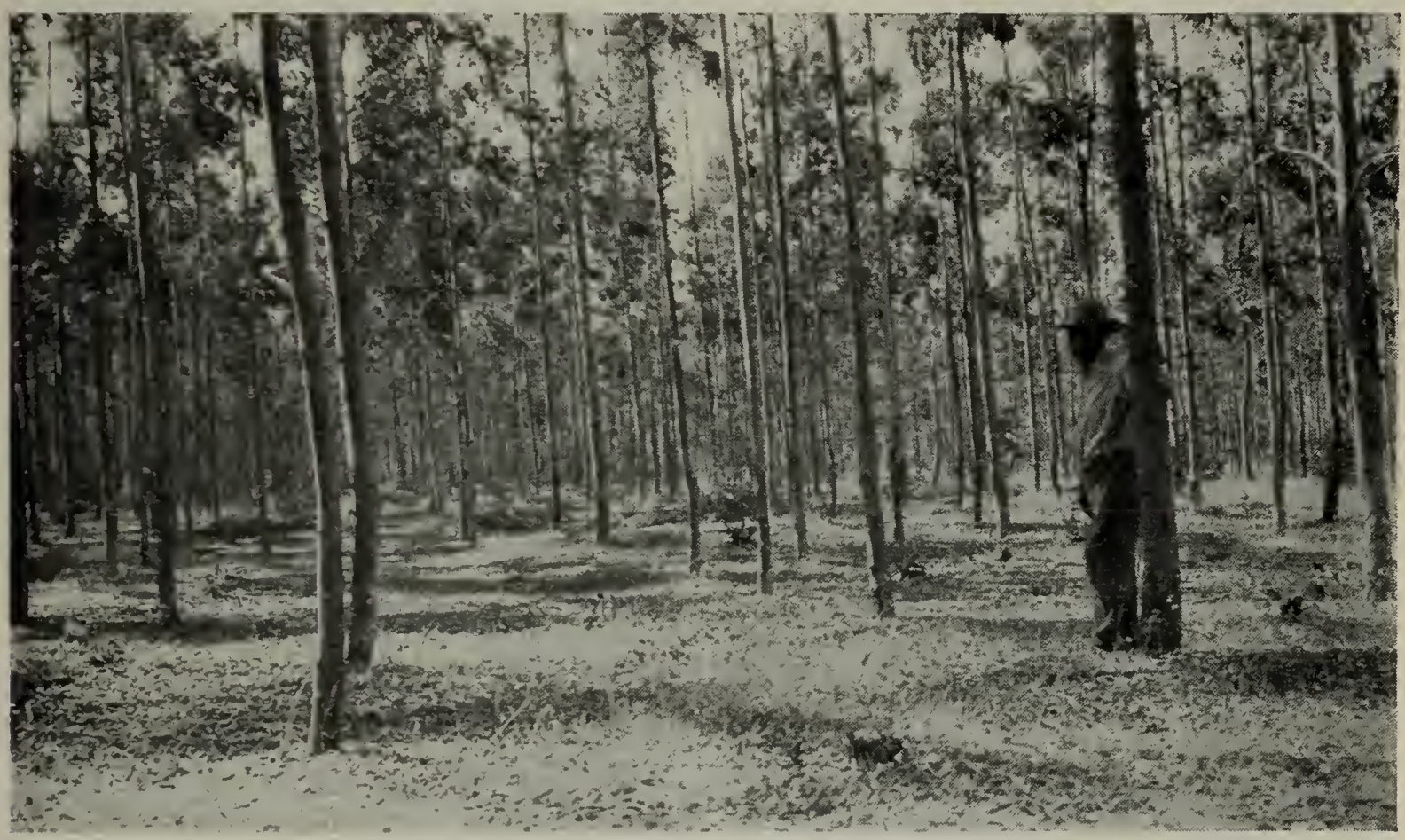

Fig. 12.-A well kept grove of Gray Gum 11 years old growing on sandy loam soil near Vacaville, Solano County. Inferior trees have been removed in thinning operations and the brush is piled ready for burning.

poorer individuals, but the mean annual growth has only been at the rate of about one cord per acre. It therefore seems unlikely that the rate of growth of this species will ever greatly exceed one cord per acre per year even on sites of better than average quality. It is recommended for its ability to grow under extreme conditions of drought, but it will not stand as much frost as eithe: Blue or Red Gums. Grove No. 16 in San Luis Obispo County, has been a complete failure because of repeated injury by frost.

\section{Sugar Gum (Eucalyptus corynocalyx-E. cladocalyx)}

Sugar Gum trees may be easily recognized by their smooth yellowish mottled trunks, the bark of which does not come off in vertical strips, but is shed in small plate-like scales. The leaves are not sickle-shaped, 
but are rather oval and blunt pointed. A prominent characteristic of this species is the reddish young foliage which makes plantations of these trees stand out clearly on the landscape. The flowers are borne in clusters of ten or more on a stalk, and the fruits are about twice the size of those of the Red Gum and rather barrel-shaped in outline. These characteristics are so definite as to make this species easily distinguished from any of the other commonly planted Eucalyptus.

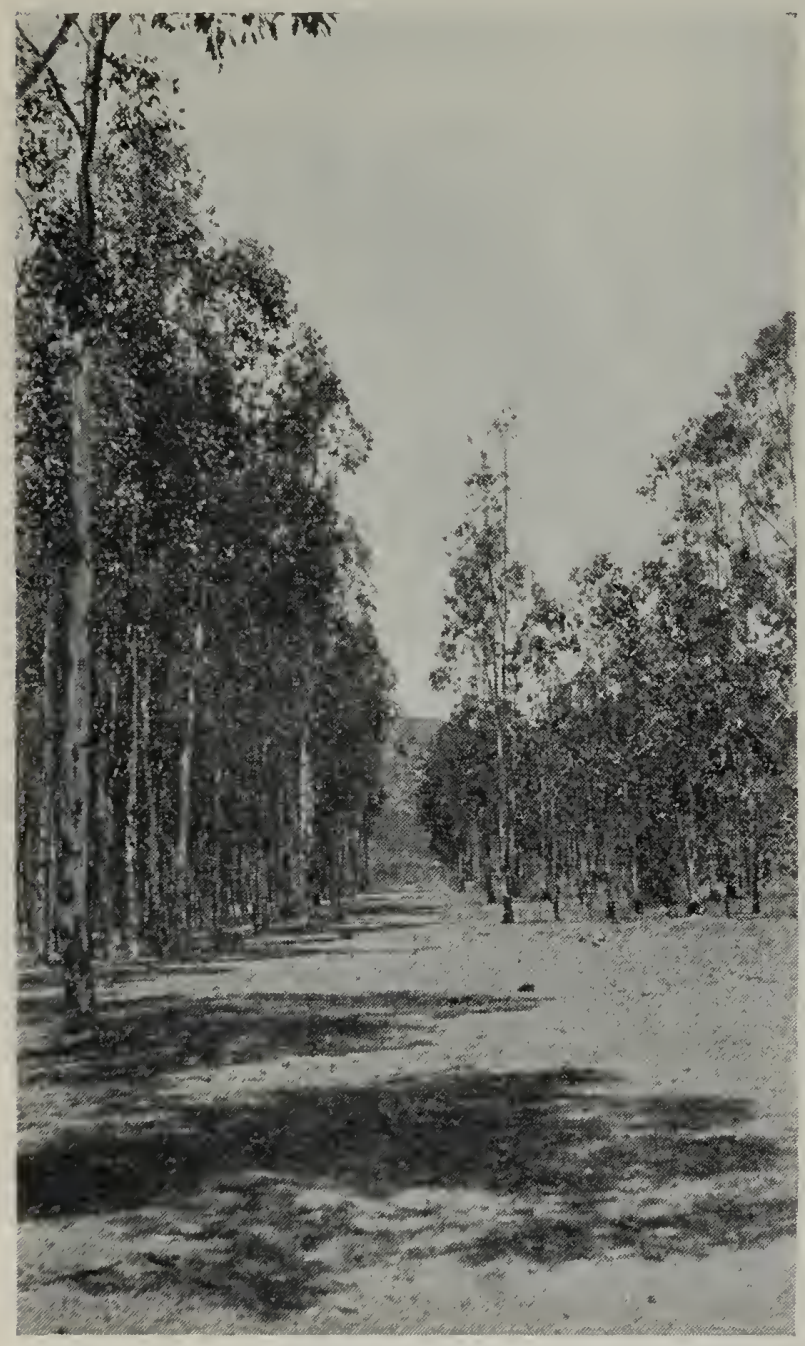

Fig. 13.

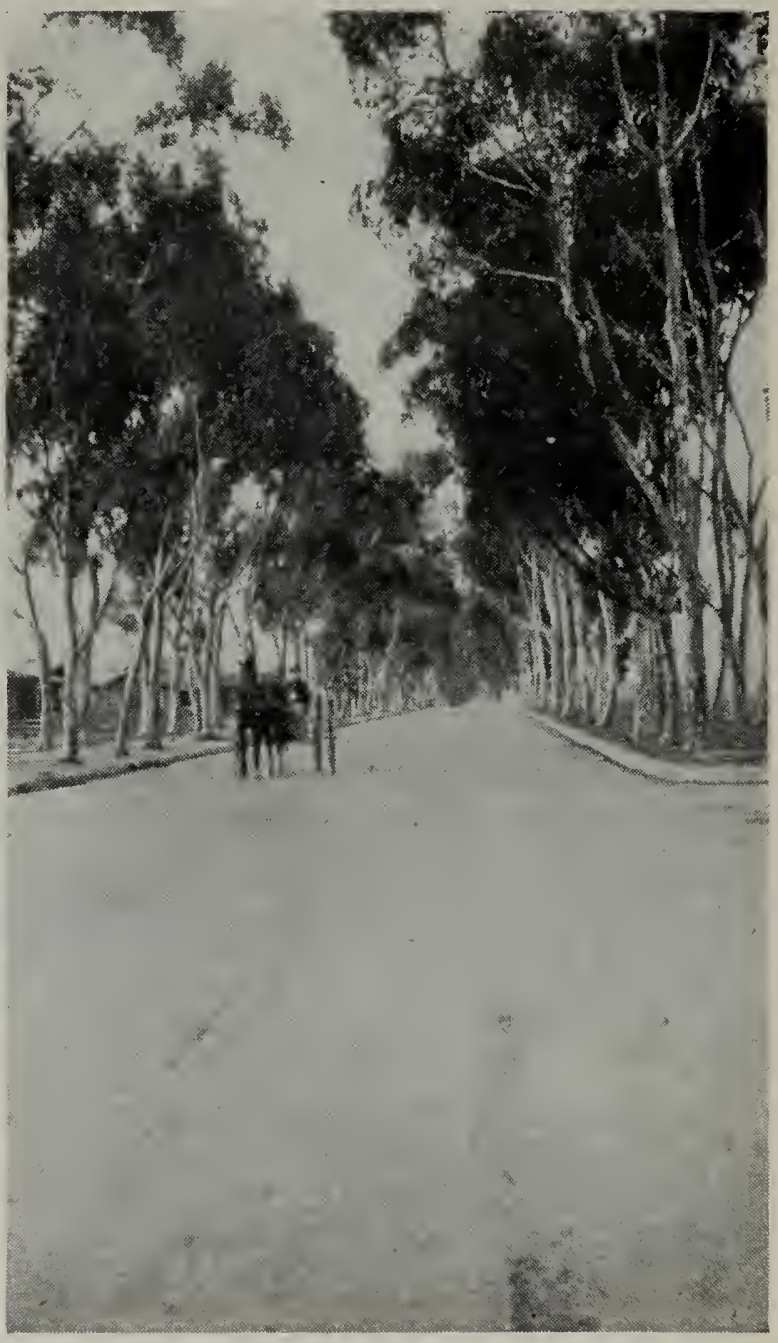

Fig. 14.

Fig. 13.-Twelve-year-old trees of Gray Gum (E. tereticornis) at the right; and Sugar Gum (E. corynocalyx) at the left, growing on the Bixby Ranch, Orange County. The Sugar Gums were removed in 1920, after water became available, and the land is now occupied by an irrigated lemon grove.

Fig. 14.--Sugar Gums lining this Santa Monica avenue are about 25 years old. The tall mottled trunks and reddish upper foliage of this species make it very desirable for street and highway planting in southern California.

The Sugar Gum is very drought resistant but is subject to injury by frost. 'Therefore it is best suited to the climate of the southern part of the state, and where planted north of Santa Barbara County, will only survive in situations which, because of favorable air drainage, are comparatively free from frost. A 20-acre plot of Sugar Gums on the 
Brintnall property in San Luis Obispo County was finally plowed out after the trees had been frozen down to the ground several times. The groves at Arden, Alameda County, are growing in a sheltered spot near the ranch buildings where the trees are protected by adjacent plantations of Blue and Red Gums. A small grove of these trees is growing on a south slope in Strawberry Canyon, Alameda County, where the trees seem never to have been injured by frost. A few trees at the Chico Forestry Station in Butte County, have been severely frozen back on several occasions. In general, it may be said that the cultivation of this species should not be attempted in the central or

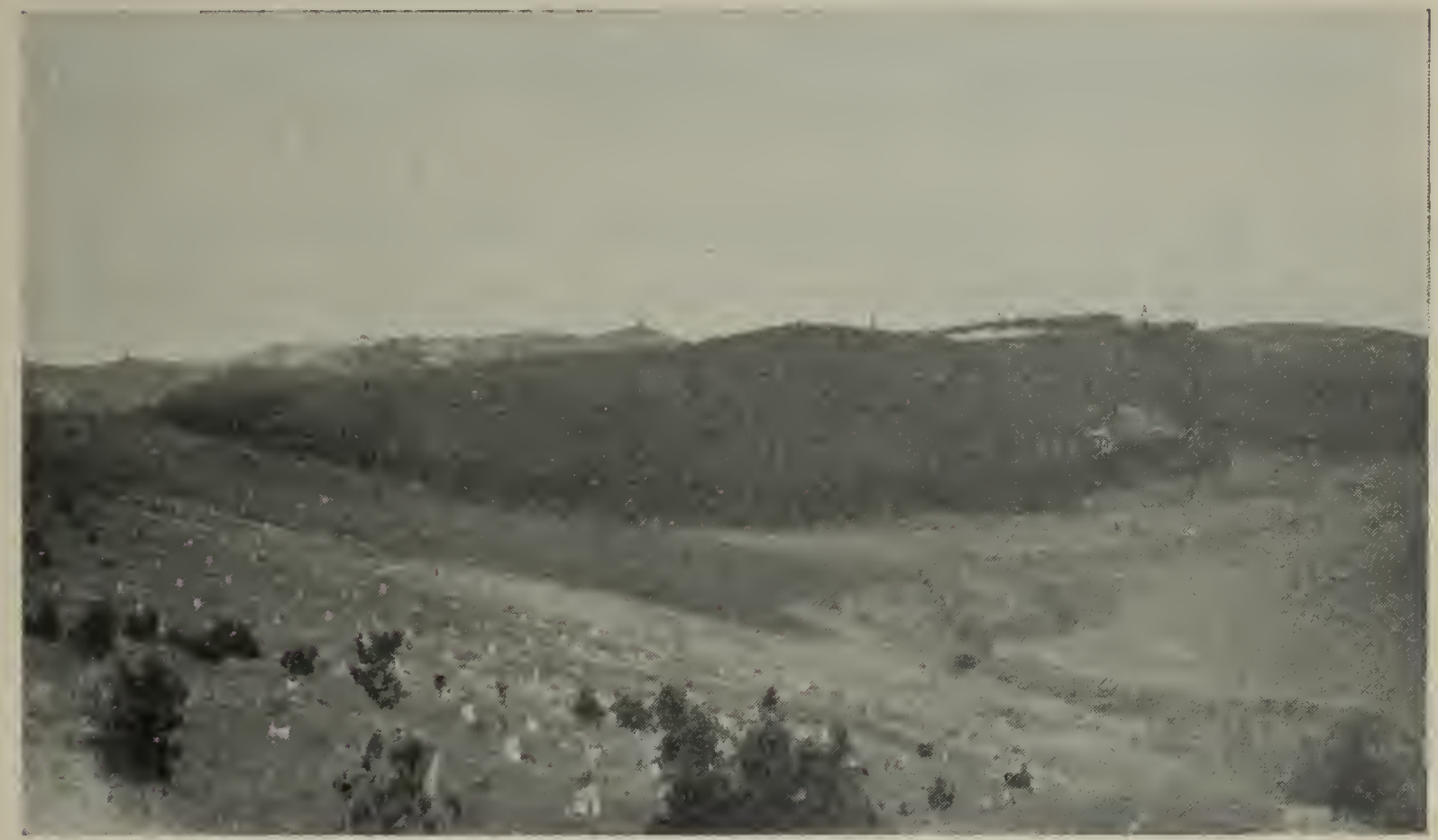

Fig. 15.-A Sugar Gum plantation on the Murphy Ranch near East Whittier, Los Angeles County. The Sugar Gum is very drought resistant but is easily injured by frost. Avocado trees in foreground.

northern parts of the state. In South Australia it is considered one of the most drought resistant species and capable of withstanding adverse treatment. In southern California it is largely planted as a highway and shade tree (fig. 14).

A summary of the growth measurements of seventeen Sugar Gum plantations is given in Table 5 from which it will be noted that the average rate of growth per year (1.22 cords) is about the same as that of Red Gum and considerably in excess of the growth made by Gray Gum. The very rapid growth made by the trees in grove No. 1, in Alameda County, may be explained by the wide spacing (15 by 16 feet), excellent soil conditions and a succession of favorable warm winters during the time that the trees were small enough to be subject 


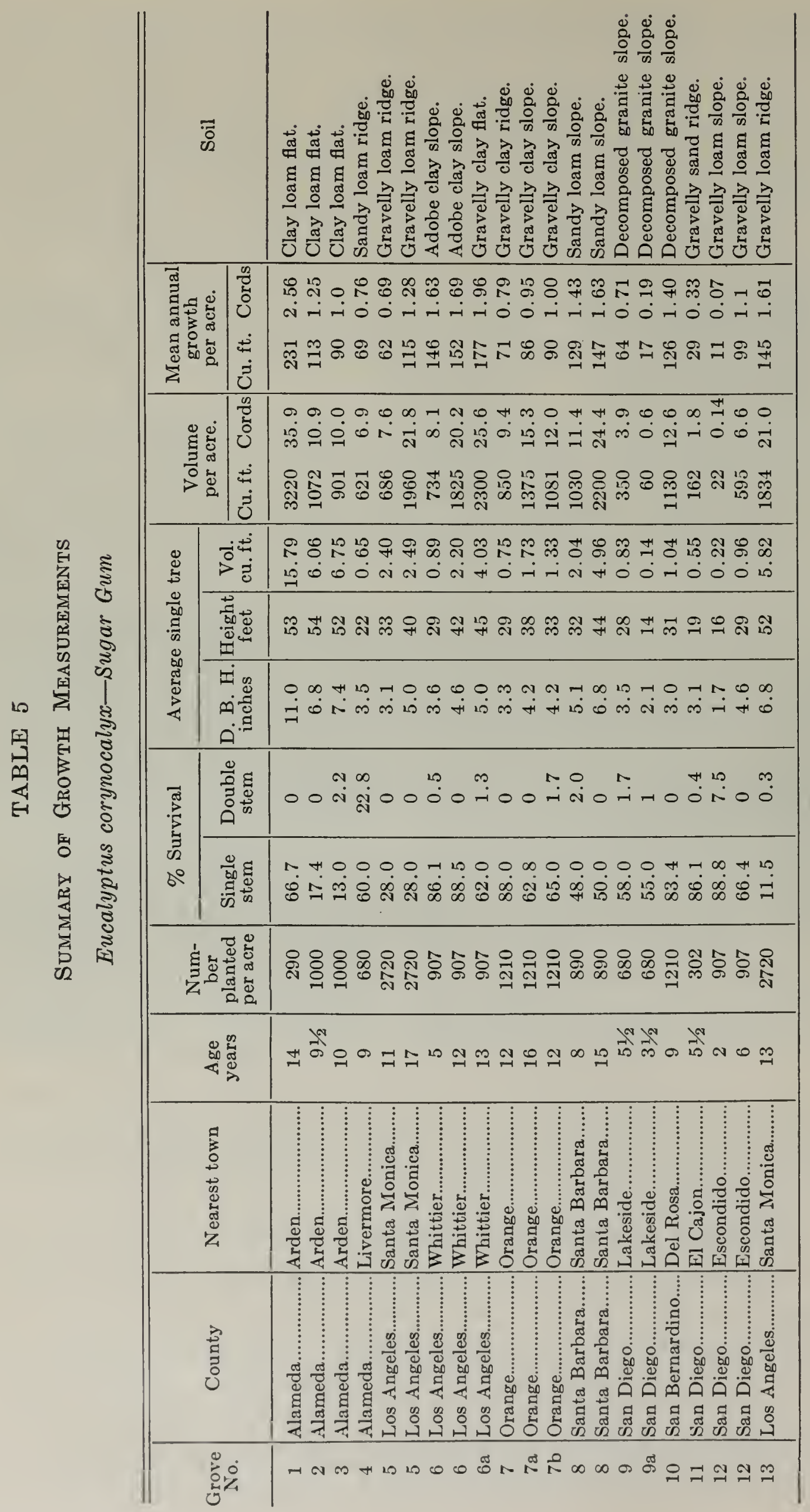


to frost injury. The growth of groves Nos. 2 and 3, although growing in soil of the same character, and within a half mile of No. 1, was slower because of severe injury from frost on several occasions and a closer spacing.

The largest Sugar Gum plantation in the state is that situated near East Whittier, Los Angeles County, on the Murphy Ranch (fig. 15). The spacing here is 6 by 8 feet and the site is a dry rolling adobe foothill slope. The trees have had no irrigation or cultivation since the year after planting, but have grown very well under the trying conditions. The grove near Santa Barbara is growing on a steep slope, has had no cultivation or care since planting, but has grown at the rate of 1.43 cords per acre per year. The foothill groves in Orange and San Diego counties show the unfavorable influence of extreme drought in the more or less stunted form of the trees and slower rate of growth (fig. 13).

While the rate of growth of this species is about the same as that of Red Gum the trees show much better form and can be used for poles or piling, for which uses the Red Gum is usually too crooked.

\section{Miscellaneous Species}

Between sixty and seventy-five species of Eucalyptus are present in California, but most of them have been set out as single trees or in small groups and are not found in plantations of any considerable size. Besides the four principal species already discussed twenty-one species were found to be growing in plantations large enough to warrant measurement. Most of these were growing only at the Santa Monica Forestry Station or in the Del Rosa experimental plantations of the U. S. Forest Service in San Bernardino County, but in a few cases plantations were found in other localities. The measurements in these various groves are summarized in Table 6, the calculations of volume being based on the Blue Gum taper measurements.

It will be noted that very few of the species shown in Table 6 compare favorably in rate of growth with the four principal species. For most of them the mean annual growth is between one-half and one cord per acre, indicating a low degree of adaptability to California conditions. A few of the more promising species may be briefly discussed as follows:

Manna Gum (E. viminalis) most nearly resembles Blue Gum in its climatic and soil requirements as well as in rate of growth. In Australia it grows to immense size ( 250 feet) but is a moisture loving tree, frequenting rich pockets in the hill country up to 4000 feet eleva- 
tion. It grows rapidly and is abundant in Tasmania and Victoria, also occurring in New South Wales and South Australia. The trunk appears in two forms, one with outer bark very rough and scaly or fibrous and adhering well up into the crown, and another with the outer bark almost entirely exfoliated, leaving a clean, smooth, white bole. The timber is not durable and is not often used. The leaves

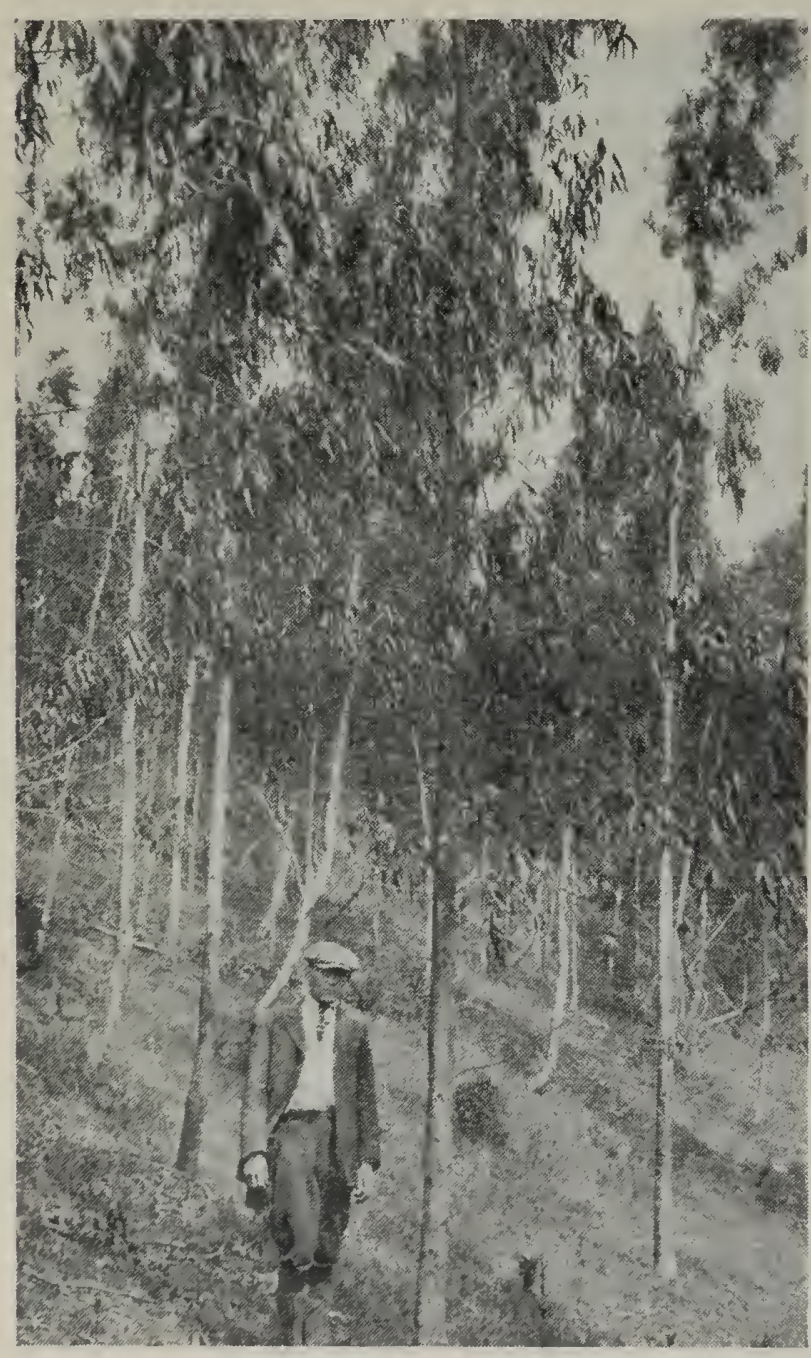

Fig. 16.

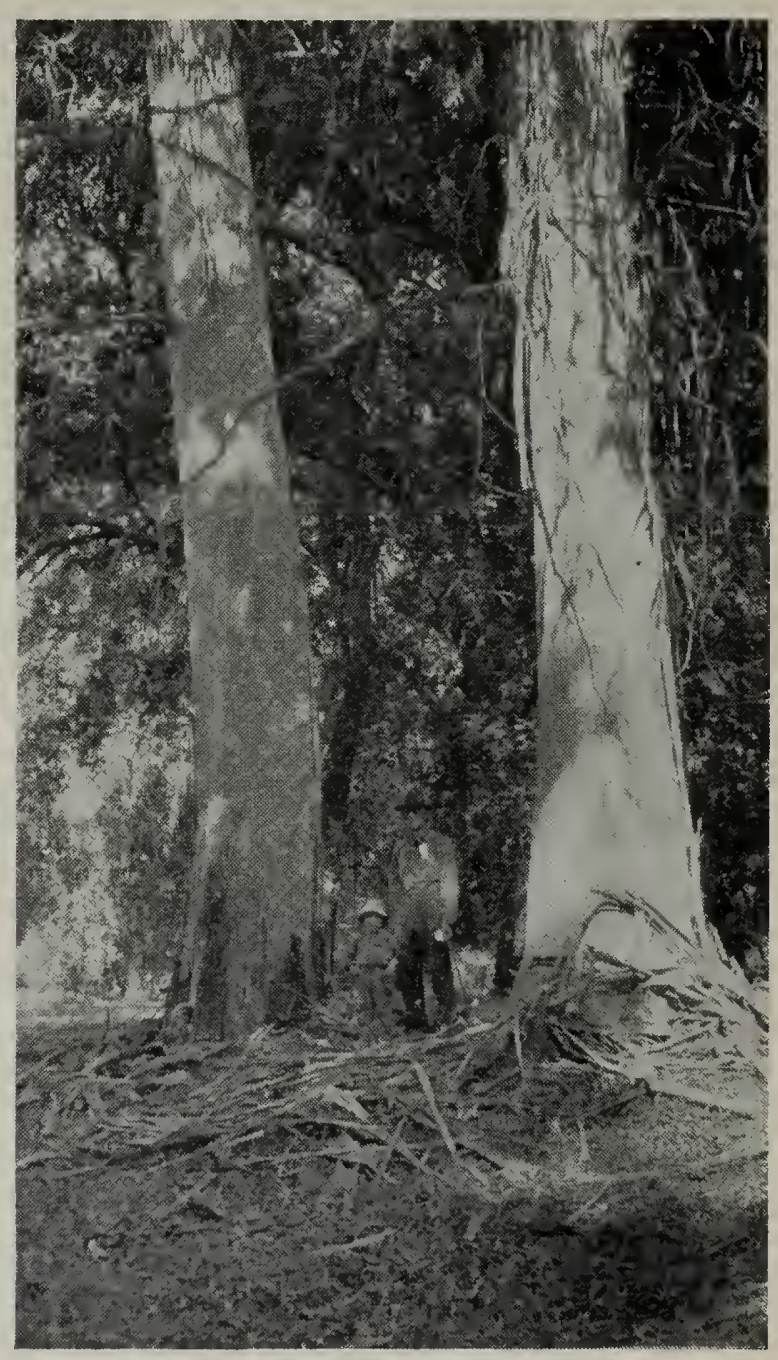

Fig. 17.

Fig. 16.-A 9-year-old grove of Manna Gum (E. viminalis) on adobe clay soil in Wildcat Canyon, Contra Costa County. The spacing is $8 \times 8$ feet. The trees have made relatively slow growth on this heavy soil and northerly exposure.

Fig. 17.-These two Manna Gums on the Chico Forestry Station, Butte County, were over 100 feet high at 28 years of age. The Manna Gum is an excellent tree for many parts of the Sacramento and San Joaquin valleys because of its resistance to frost injury and its rapidity of growth.

shed a sort of "manna," whence its name. The latter characteristic has not been noted in California plantations, but the species may be easily recognịed by its straight, cylindrical, usually chalky white trunk; narrow sickle-shaped leaves; and small, green shoe-button-like fruits which are usually borne in threes in the shape of a cross. Groves 1 and 4 indicate the rapid growth of this species in the central coast 
counties when widely spaced on fairly good soil. Grove 5 in Contra Costa County has made poorer growth, as the soil is a heavy adobe clay and the situation is a cold, northeast slope (fig. 16). The spacing in this grove was also closer than in groves 1 and 4. Manna Gum seems poorly suited to climatic and soil conditions of southern California; large losses occurred in the mesa plantation at Santa Monica, while the best trees in this part of the state were growing on fertile, sandy loam bottomland near the Santa Ana River in Orange County.

One of the largest Manna Gum trees in the state is situated on the ranch of J. C. McCubbin near Reedley, Tulare County. This tree is growing in the open and has received soil moisture in large quantities from the irrigation of adjacent vineyards. Other fine specimens are growing in the San Joaquin County Hospital grounds near Stockton, in the parks of Sacramento, and at many other points in the Great Valley. A group of about 25 trees at the Chico Forestry Station, Butte County, have grown more rapidly and are larger and more perfect in their development than any other trees on the station (fig. 17). They have at all times of the year an adequate supply of soil moisture from a nearby creek. Well grown individual trees have been noted as far north along the coast as Humboldt County and in every case the trees seem very frost hardy. It seems evident that Manna Gum is second only to Blue Gum in rate of growth and adaptability to a wide range of California conditions, but like Blue Gum, it has the disadvantage of producing a poorer quality of wood than that of many other Eucalyptus.

Red Ironbark ( $E$. sideroxylon) often called Black Ironbark, is widely distributed but not very abundant in Victoria, New South Wales and Queensland at elevations below 2000 feet where mature trees yield excellent hard, dark red, durable timber, but clear lumber is hard to get because of the presence of "shake" or resin pockets. It seems not to be thoroughly at home in California and plantations have grown with only moderate rapidity. The species may be recognized by its coal-black, furrowed bark, which is full of grains of shiny, resinous kino. The foliage is bluish green and the ultimate branchlets have a gracefully weeping habit. The flowers are pink or reddish in color and the fruits are goblet shaped, about three-fourths of an inch in length, shiny purplish brown in color and they occur in threes on long stalks. Red Ironbark is one of the most beautiful trees in the mixed plantation at Santa Monica but when grown in the open it has not been satisfactory because of severe damage by wind (fig. 18). The species is not very frost hardy and in general cannot be considered very satisfactory for growing in California. 
White Ironbark (E. leucoxylon) is somewhat similar to the preceding species in regard to its leaves, flowers and fruits, but may usually be easily distinguished by its smooth, chalky-white bark. In Australia it is a medium sized tree with coarse outer bark, which is often persistent so as not to expose the clear white inner bark. Wood from mature

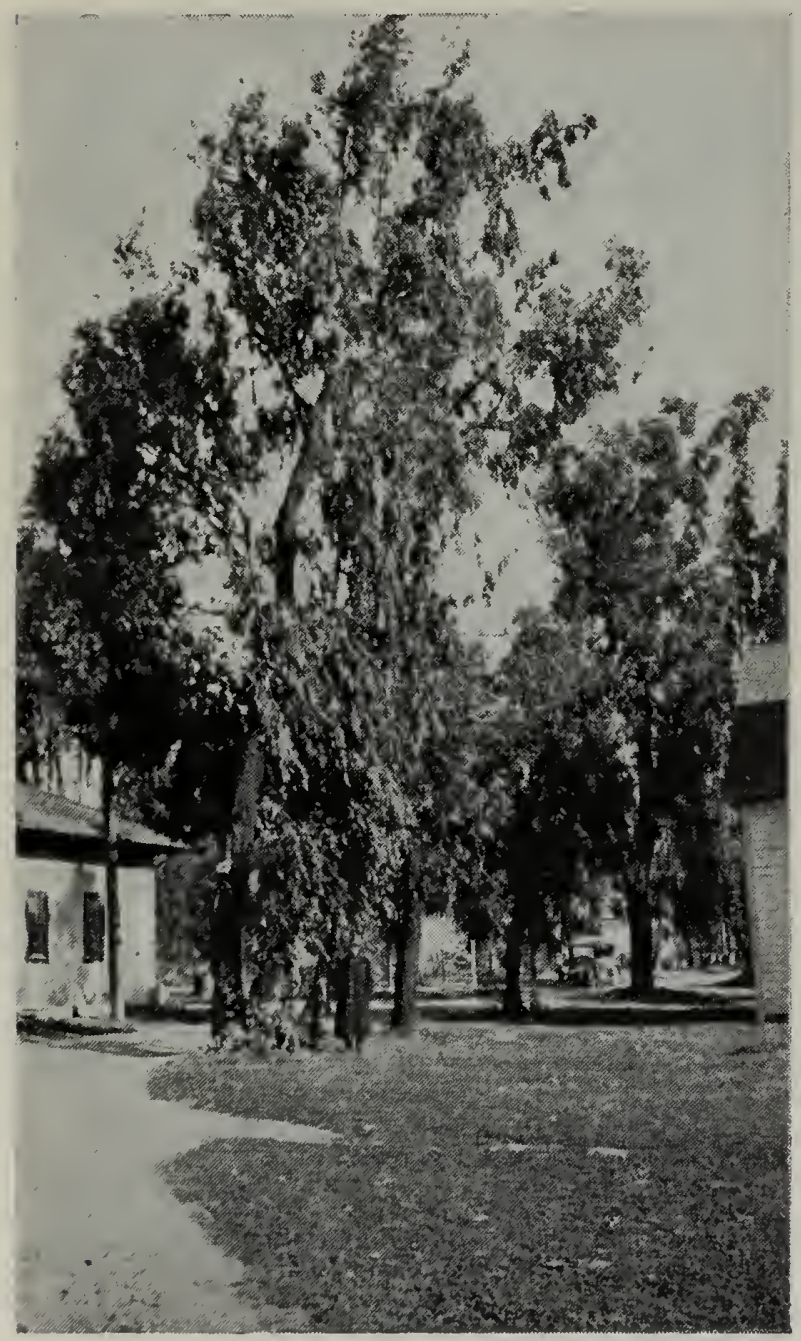

Fig. 18.

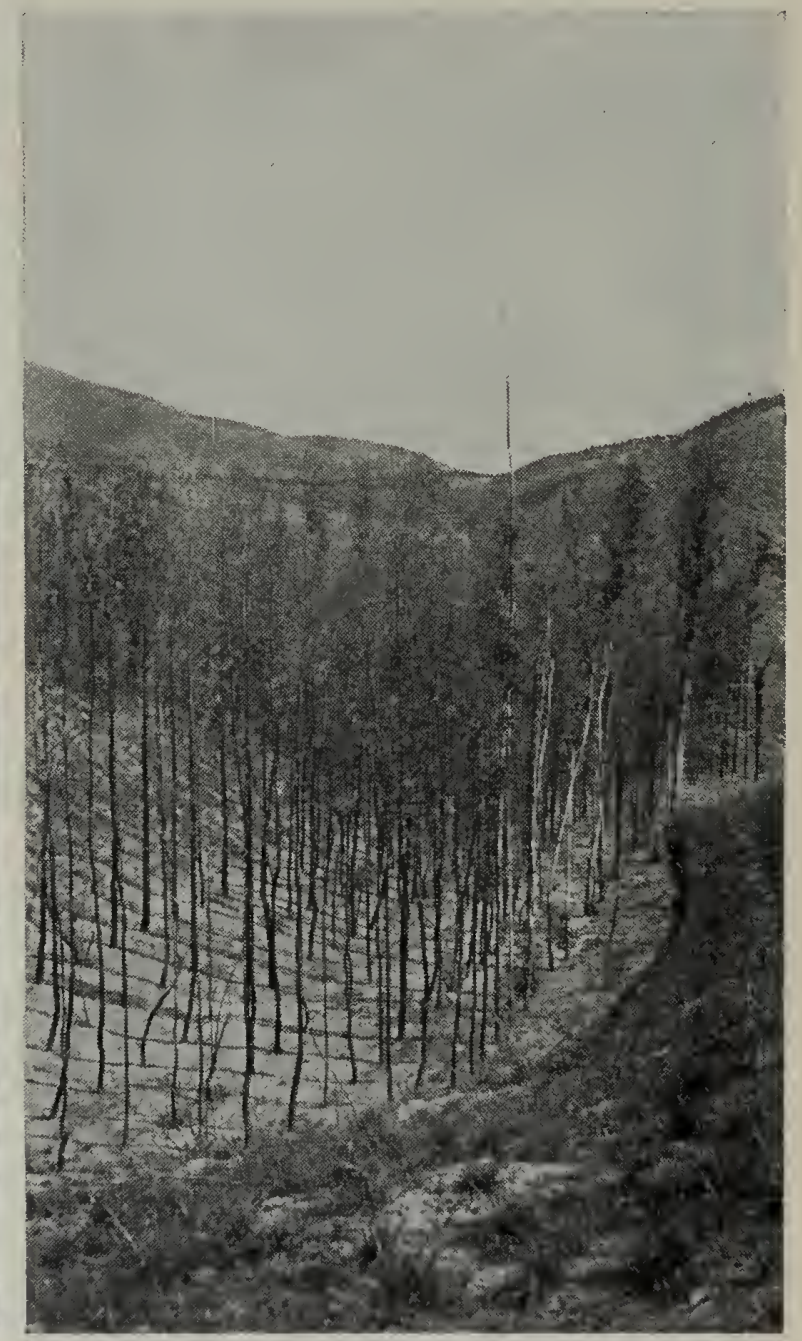

Fig. 19.

Fig. 18.- Red Iron bark (E. sideroxylon) is a beautiful ornamental tree for parts of southern California but when grown farther north, it has been subject to damage by wind and frost. The poor form of these street trees in Decoto, Alameda County, emphasizes this point.

Fig. 19-Red Ironbark and Manna Gum growing near Del Rosa, San Bernardino County, made fairly good growth for such a dry site. The picture was taken six months after all of these experimental plantations had been completely destroyed by the severe fire of October, 1922. Plantations are very subject to fire damage and should be carefully protected.

Australian trees is light pinkish gray in color and dries well but slowly. It is durable and makes good but hard lumber. In California, White Ironbark is not a straight tree, but usually grows with a somewhat twisted and branched trunk. Its light yellow or pink flowers are produced in great profusion and these with the white, irregular shaped 
trunk make the tree very desirable for ornamental purposes. The three groves measured indicate that under fairly good soil conditions in southern California this species will produce slightly more than one cord per acre per year. Very few trees of this species have been planted in the central or northern part of the state, and practically all of those observed show more or less serious frost injury. A single White Ironbark on the Chico Forestry Station has a short, scrubby, much branched top, the result of repeated freezing back; and a tree on the campus at Berkeley is very similar in its habit of growth. The species cannot be recommended for planting outside of southern California except in sheltered, frostless situations.

Red or Forest Mahogany (E. resinifera) in its native habitat is a medium size tree of local distribution in the coast regions of New South Wales and Queensland, usually scattered in stands of other species on moist sites but is sometimes found on dry hillsides. The lumber is straight grained and works well, but is not durable. The timber is not extensively used, probably because of its scattered distribution. In California, when grown under good conditions of soil, moisture and climate, the Red Mahogany produces a splendid straight stem clothed with soft fibrous reddish bark. The leaves are thick and glossy green and borne on dark red twigs while the clustered fruits are slightly constricted at the base. All of these characteristics make the tree easy to recognize. The chief difficulty with this species is its susceptibility to frost. Preliminary tests of the wood showed it to be superior to most Eucalyptus grown in California, but frost injury has caused the removal of several groves of this species and it cannot be considered a satisfactory tree except in nearly frost free localities. It is very desirable as a decorative tree for southern California, and although its growth is only moderately rapid, its good form and the comparative durability of its wood may make this species suitable for poles and piling. It cannot be grown satisfactorily in the central or northern parts of the state.

Sydney Bluc Gum or Flooded Gum (E. saligna) and Swamp Mahogany (E. botryoides) are very similar in character except that the former has a smooth whitish or greenish upper bark and is a large tree, while the latter has coarse, rough bark throughout and is smaller and scrubbier. Dr. Maiden is inclined to consider botryoides as a variety of saligna. In New South Wales and Queensland both trees grow best on moist bottom lands, damp valleys and hollows of the mountains. The wood of saligna is one of the best very hard woods of eastern Australia. It is tough, very hard, of a bright pink color and is straight grained with a somewhat interlocking fiber. It is highly 
valued for wagonwheel felloes and hubs, and being very durable is extensively used for railway ties and in boat building. $E$. botryoides is said to be the finest shade tree among the Eucalypts for Australian conditions.

Fine specimen trees of both Flooded Gum and Swamp Mahogany are present in the mixed plantation at the Santa Monica Station, but since both are moisture loving species, they cannot be expected to make very satisfactory growth on most of the semi-arid sites in California without irrigation. It is rather remarkable that both have grown at the rate of over one cord per acre per year on sites as dry as those at Santa Monica and in the Livermore Hills. As neither of these trees is especially frost hardy, they should be planted with caution except in sheltered or frost free situations.

Karri ( $E$. diversicolor) is the giant tree of Western Australia which reaches a height of 300 feet and vies with the Victorian Mountain Ash (E. regnans) for supremacy in size among Australian trees. Karri grows in a comparatively small region usually on damp, rich flats where no frost occurs. Its wood is bright cherry red, is very hard, not durable, and checks badly in drying, but because of the great size of the trees, timber may be obtained in immense sizes free from all defects and great quantities of it are exported as railway ties or scantlings. Karri is apparently poorly suited to California conditions, being slow in rate of growth and easily injured by frost and wind. Individual Karri trees at Santa Monica have outstripped all other species in rate of height growth, but growth in plantations has not been satisfactory. This species will not succed except in sheltered and practically frost free situations.

Messmate Stringybark ( $E$. obliqua) although rare in plantations is deserving of special mention because of its frost hardiness. In its native region it grows very tall (250 feet) and it is considered one of the hardiest timber trees in Australia. In Tasmania, Victoria and New South Wales it is a common associate of the Giant Gum ( $E$. regnans) and above 2000 feet elevation it forms mixed stands with $E$. delegatensis, another very hardy species which has not as yet been tried in California. The two species are cut together and sold as "Tasmanian Oak," used mainly for car construction. The Messmate Stringybark is a rough barked tree, very straight and tall, and the timber is extensively used for scantlings and rough construction. Although fairly durable the timber is usually of very poor quality on account of numerous pockets filled with red, liquid kino gum. It chacks badly in drying, and is generally inferior to the Mountain Ash (E. regnans) for building and carpentry. Del Rosa is the only place 
in California where this species is growing in plantation form but individual specimens are found at many points in the state. At the Chico Station in Butte County this tree has made individual growth which is exceeded only by Manna Gum, Blue Gum and Red Gum, and many fine trees of this species are growing in the San Francisco Bay region. These trees are easily recognizable by their rough, fibrous bark

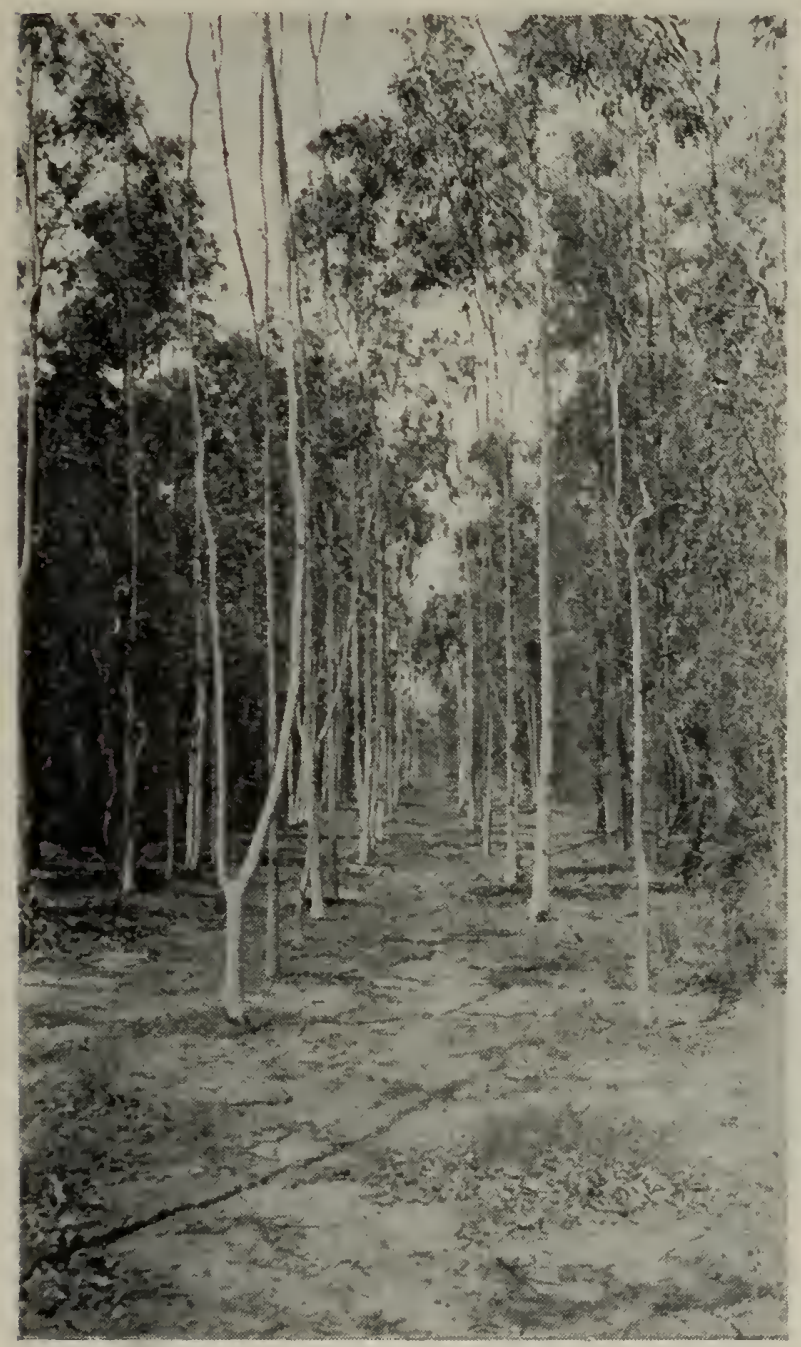

Fig. 20.

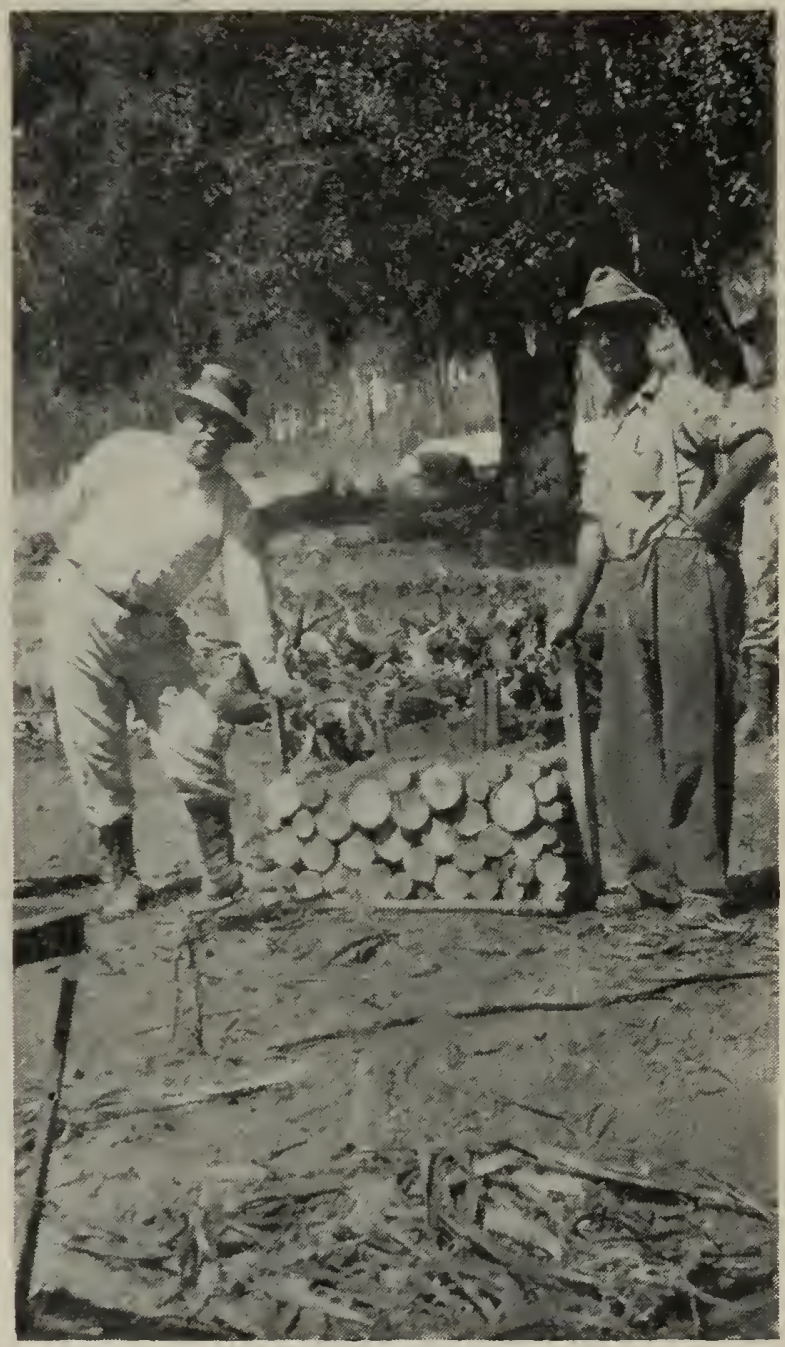

Fig. 21.

Fig. 20.- Specimen rows of Lemon Scented Gum (E. maculata citriodora) which have persisted on the dry gravelly foothill soil of the Bixby Ranch, Orange County, but have made very slow growth. On good soil and with some irrigation, this is a beautiful ornamental tree.

Fig. 21.-This pile of 12-inch cordwood was cut from an average tree (4.8 inches by 53 feet) in a 71/2-year-old Blue Gum grove near Lakeside, San Diego County.- When stacked as shown, it measured $3 \frac{4}{4}$ stacked cubic feet, or 34 such trees are required to produce one standard cord of 12 -inch fire wood. Fuel is the chief use to which the California grown Eucalyptus have been put.

and the unsymmetrical form of the base of the leaves. It seems certain that this tree will do well in plantations under a variety of California conditions, but the wood, being of such inferior quality in Australia, will probably be suitable only for fuel. 


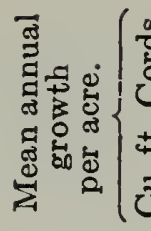

子

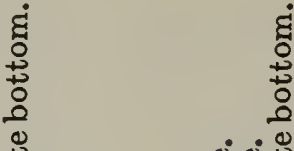

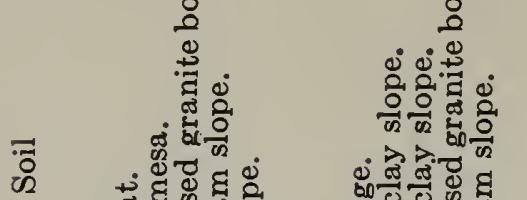

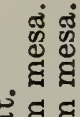

离

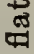

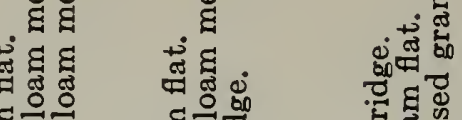

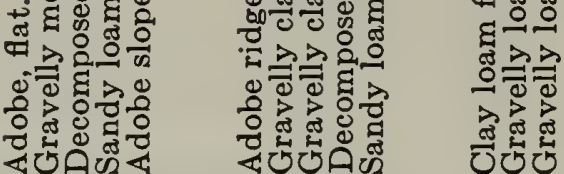

อ글

듀유.

을 을

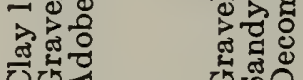

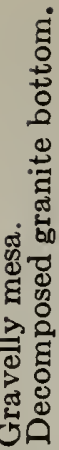

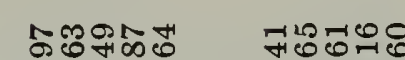

OUO 00

ऊัน

깍아

तi०० भु

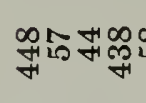

nolog

证

H

क्ल

000

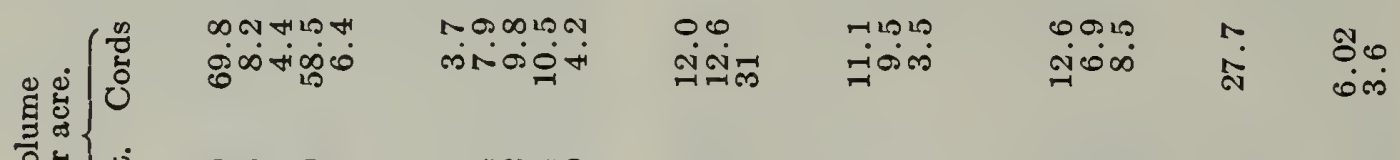

留

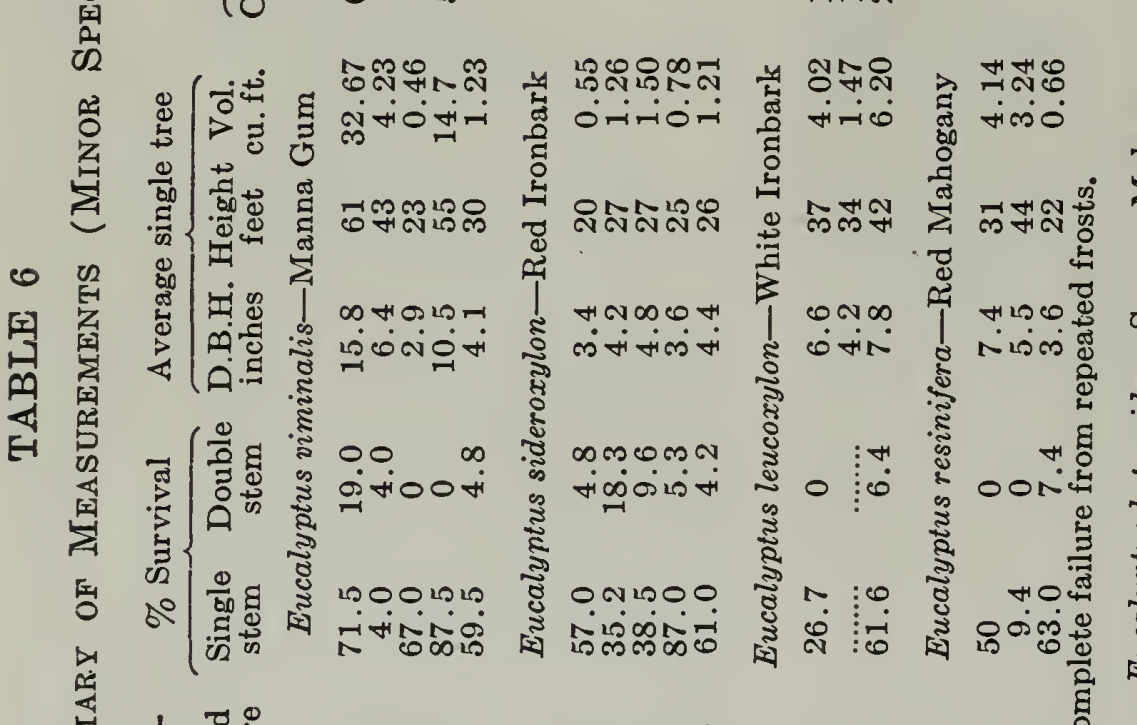

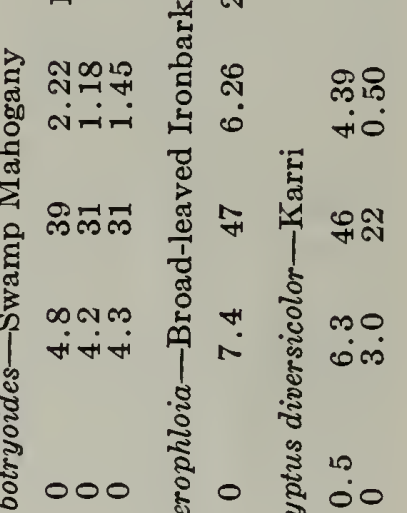

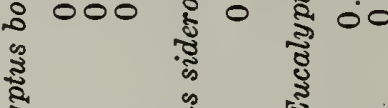

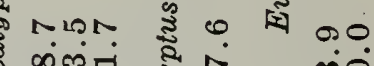

करन है

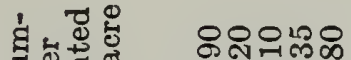

Niñ

오욱은 유

옳요

ชิธิณ

이

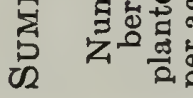

品

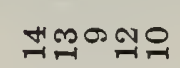

orgen

으ำ

어ㅁㅓㅔ

700 ปิ

\& 옹ํㅗㄱ
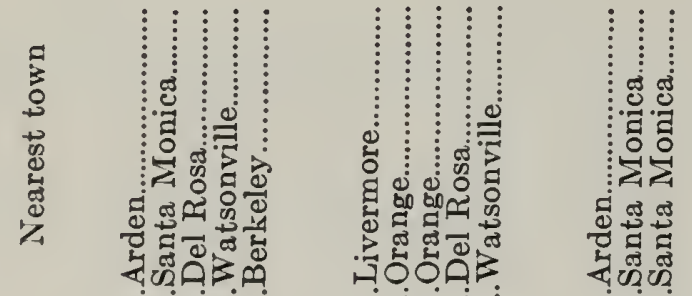

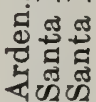

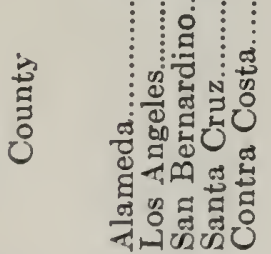
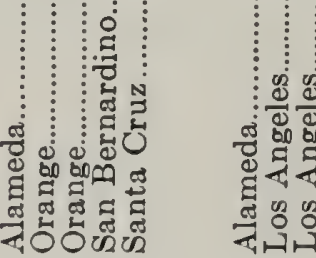

㻤它

नलक्ष

नलNकम

नल⿻

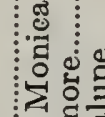

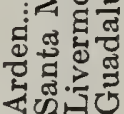

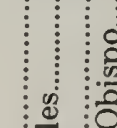

我

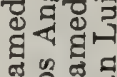

घू हूँ

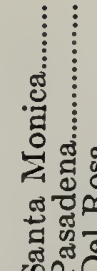

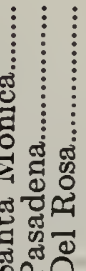

ลี

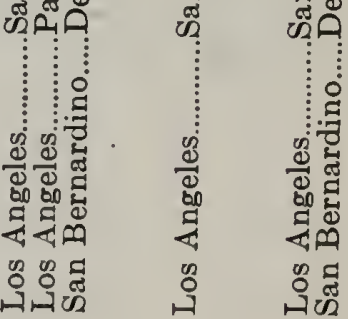

नल⿻卄

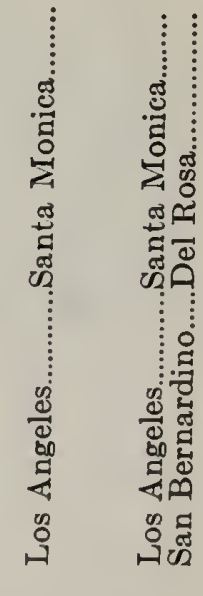


Bulletin 380] GROWTH OF EUCALyptus IN CALIFORNiA Plantations 33

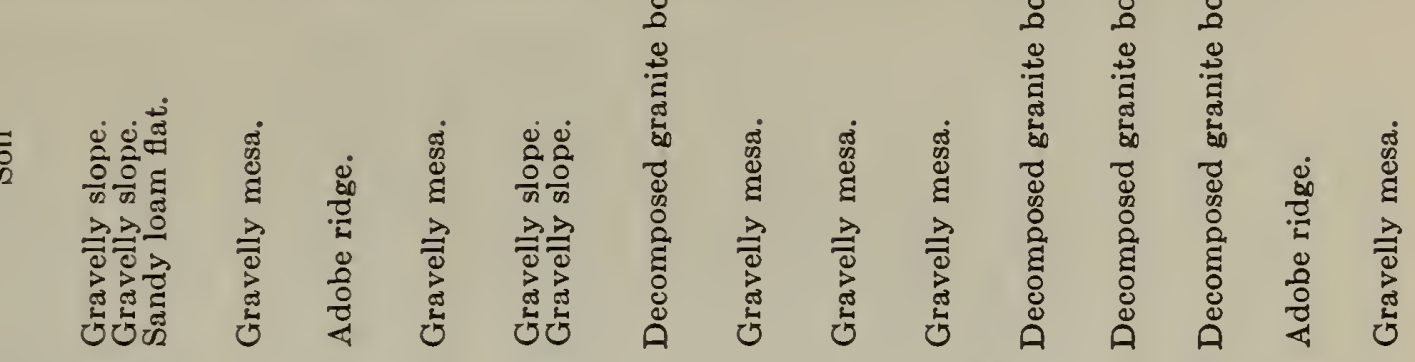

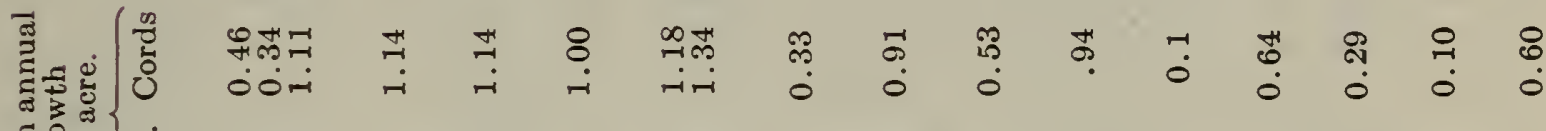

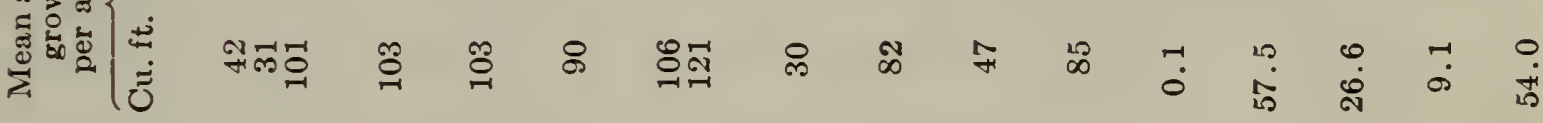

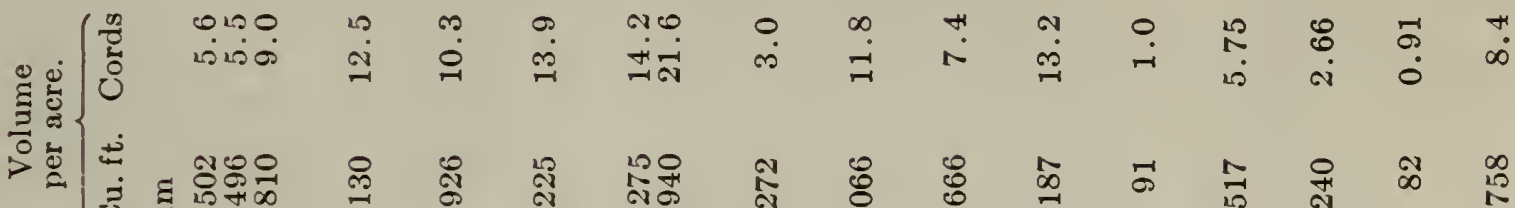

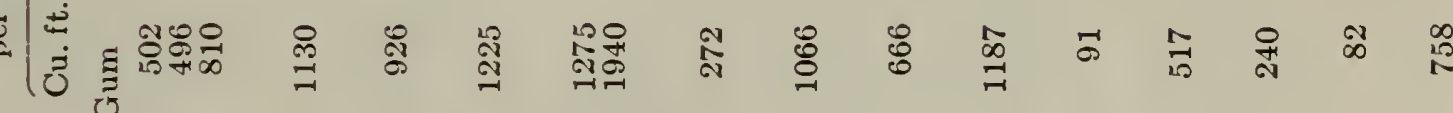

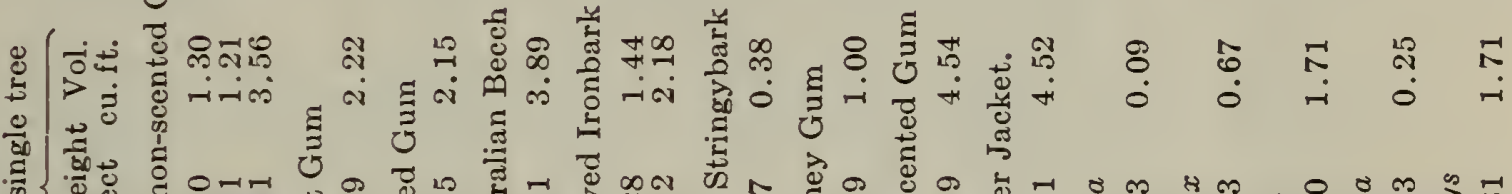

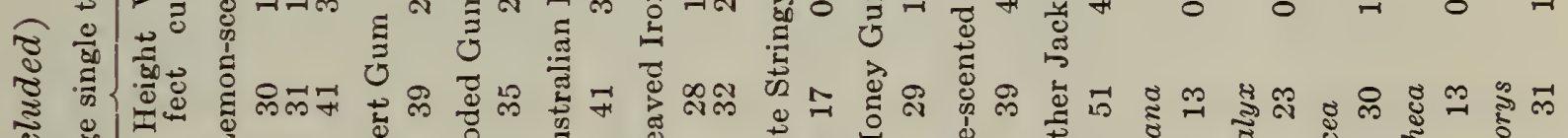

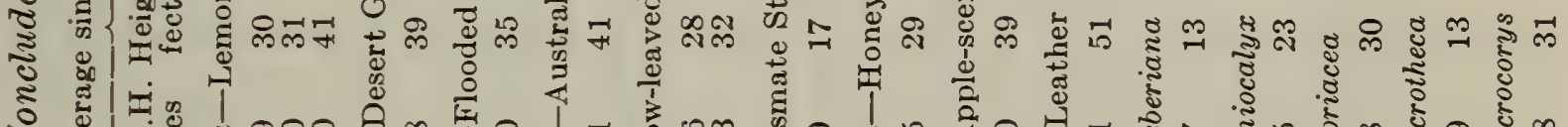

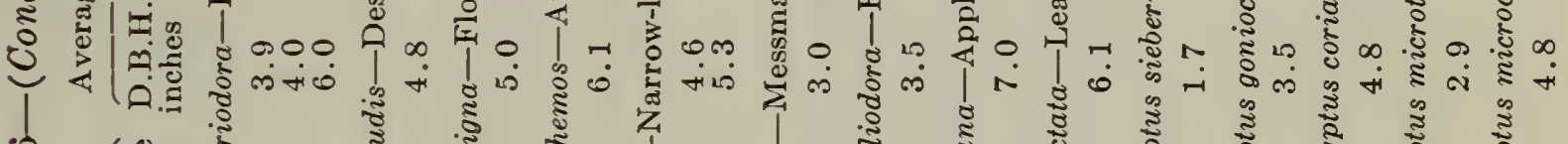

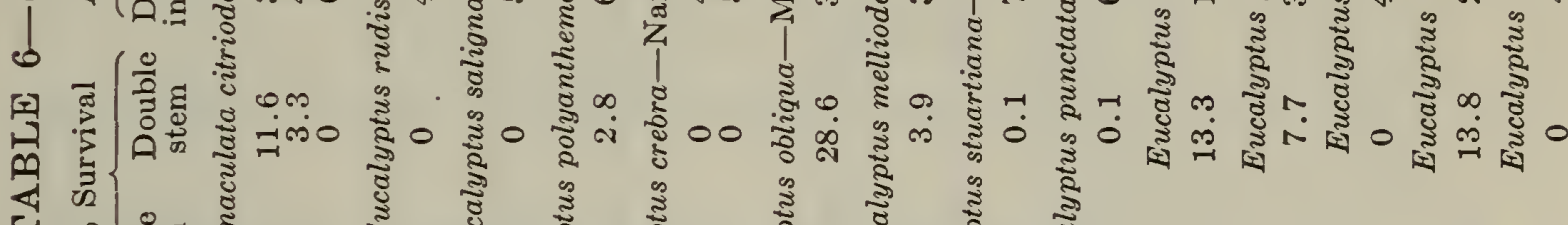

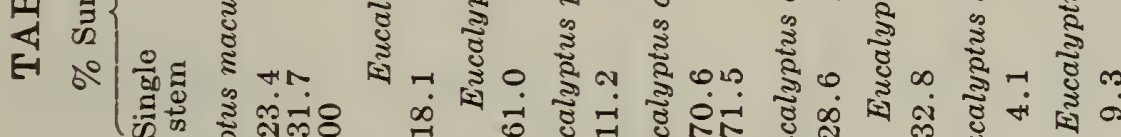

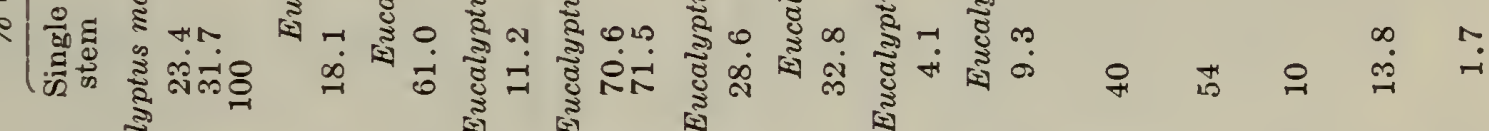

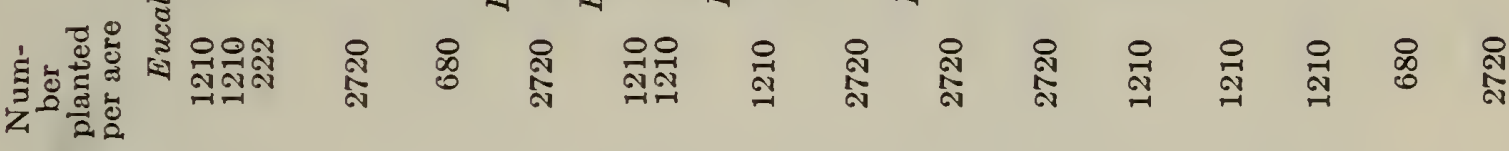
影

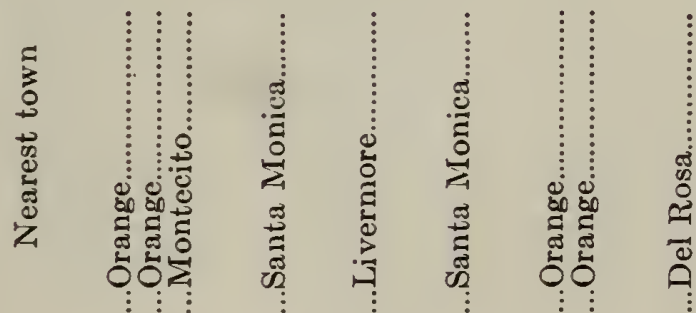

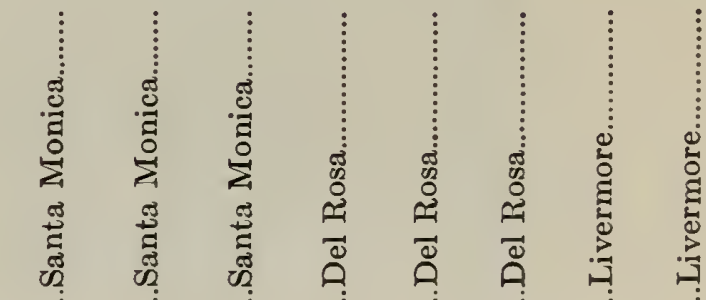

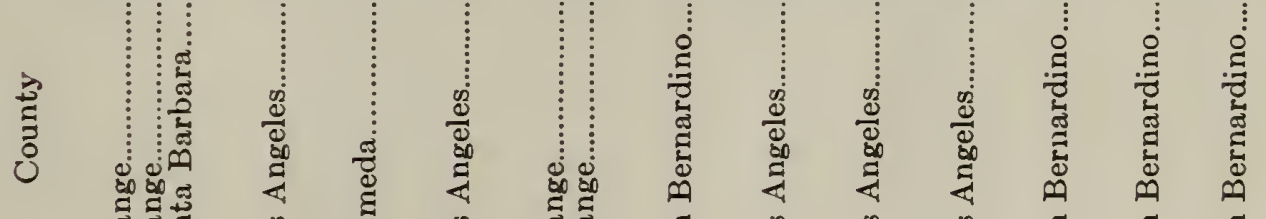

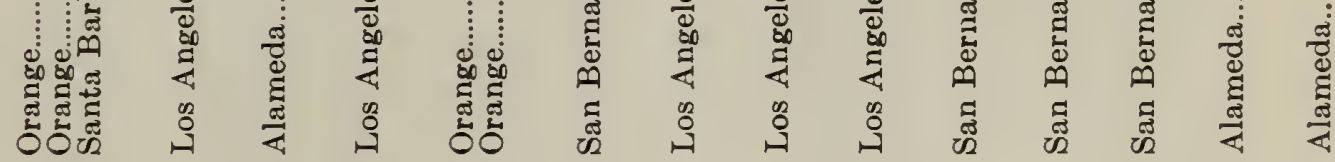

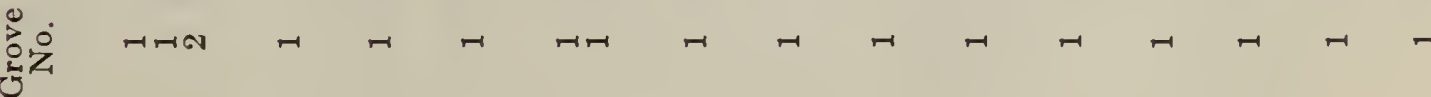


Growth in Mixed Stands at Santa Monica Station, Los Angeles County.

In 1890 a portion of the Santa Monica Forestry Station surrounding the buildings was set aside for use as an arboretum in which trees could be grown in mixed stand and with irregular spacing. A number of species were planted that year and the collection was added to as seedlings became available. The result is a mixed stand containing the largest number of Eucalyptus species in the state; a stand in which except for competition with each other, the individual species have had the opportunity for unrestricted development. The spacing was wide enough so that competition has not been unduly severe in most cases and the area received thorough cultivation annually for a much longer period than is usual in plantations. The soil is a sedimentary gravelly loam of open texture and only moderate fertility on which the raising of farm crops is impossible without irrigation. The Eucalyptus trees have not been irrigated.

A summary of the measurements of trees of different ages in this mixed stand is given in Table 7 in which the different species are arranged alphabetically. Some of the trees have made really remarkable growth when it is considered that the mesa on which they stand is about as poor and dry a site as any that could be found adjacent to the coast in southern California. The factor most favorable to the trees is the high humidity of the ocean winds during the otherwise dry summer months.

When measured, the oldest trees in this plantation were 27 years old. The leading species in diameter growth at this age were the following :

Inches d.b.h

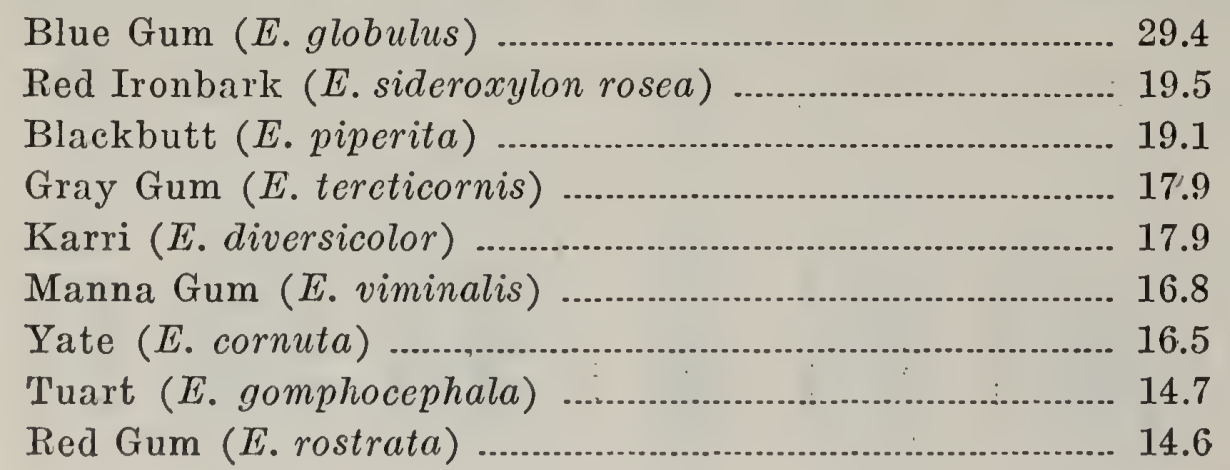


TABLE 7

Growth of Specimen Eucalypts, Santa Monica Forestry Station, Los ANgEles Coun'Ty

\begin{tabular}{|c|c|c|c|c|c|c|c|c|}
\hline Plot & Species & $\begin{array}{c}\text { Date } \\
\text { of } \\
\text { plant- } \\
\text { ing }\end{array}$ & $\begin{array}{c}\text { Age } \\
\text { years }\end{array}$ & $\begin{array}{c}\text { Num- } \\
\text { ber of } \\
\text { trees } \\
\text { meas- } \\
\text { ured }\end{array}$ & d. b. h. & Height & Form & Remarks \\
\hline A & E. amygdalina. & 1890 & 27 & 1 & 8.2 & 42 & Crooked.. & \\
\hline M & E. amygdalina numerosa... & 1897 & 20 & 1 & 7.2 & 28 & Fair......... & \\
\hline$M$ & 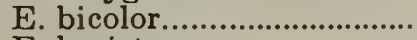 & 1897 & 20 & $\overline{6}$ & 5.8 & 35 & Fair.. & \\
\hline $\mathrm{G}$ & E. bosistoana ....................... & 1911 & 16 & 2 & 8.6 & 34 & Good. & \\
\hline$M$ & E. botryoides... & 1897 & 20 & 10 & 7.9 & 38 & Branching....... & Fair. \\
\hline A & E. calophylla... & 1890 & 27 & 2 & 13.9 & 48 & Branching........ & Thrifty. \\
\hline M & E. calophylla.. & 1897 & 20 & 6 & 9.1 & 36 & Branching............. & Fair. \\
\hline A & E. citriodora... & 1890 & 27 & 5 & 10.1 & 50 & Straight... & Fair. \\
\hline A & E. citriodora.... & sprouts & 13 & 8 & 4.0 & 26 & Straight... & Fair. \\
\hline A & E. coriacea........................... & 1890 & 27 & 1 & 5.0 & 35 & Crooked... & Dying. \\
\hline $\mathbf{A}$ & 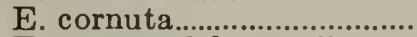 & 1890 & 27 & 7 & 16.5 & 46 & Branching....... & Thrifty. \\
\hline A & E. cornuta lehmannii.. & 1890 & 27 & 2 & 7.8 & 40 & Branching..... & Thrifty. \\
\hline M & E. cornuta lehmannii....... & 1897 & 20 & 2 & 2.5 & 20 & Scrubby............ & Fair. \\
\hline A & 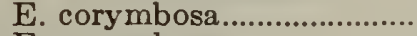 & 1890 & 27 & 3 & 11.5 & 62 & Straight......... & Thrifty. \\
\hline $\mathbf{M}$ & E. corymbosa... & 1897 & 20 & 6 & 4.5 & 24 & Scrubby..... & Fair. \\
\hline A & E. corynocalyx... & 1890 & 27 & 3 & 13.7 & 76 & Straight..... & Thrifty. \\
\hline $\mathrm{G}$ & E. corynocaly $x . . . . . . . .$. & 1911 & 16 & 2 & 6.6 & 39 & Straight........ & Fair. \\
\hline M & E. cosmophylla................... & 1897 & 20 & 2 & 5.7 & 29 & Scrubby............ & Poor. \\
\hline $\mathrm{M}$ & E. decipiens................... & 1897 & 20 & 6 & 5.3 & 24 & Scrubby........ & Fair. \\
\hline A & E. diversicolor.... & 1890 & 27 & 2 & 17.9 & 97 & Straight.... & Thrifty. \\
\hline G & E. diversicolor... & 1911 & 16 & 3 & 7.1 & 34 & Straight.... & Good. \\
\hline $\bar{A}$ & E. eugenioides... & 1890 & 27 & 1 & 10.0 & 59 & Straight.... & Thrifty. \\
\hline G & E. eugenioides... & 1911 & 16 & 4 & 4.6 & 24 & Good...... & Fair. \\
\hline A & E. ficifolia ............................. & 1890 & 27 & 3 & 12.4 & 22 & Branching.... & Thrifty. \\
\hline A & E. globulus.... & 1890 & 27 & 1 & 29.4 & 69 & Spreading top.. & Thrifty. \\
\hline $\mathbf{A}$ & E. gomphocephala........... & 1890 & 27 & 5 & 14.7 & 69 & Fork tops........ & Thrifty. \\
\hline $\mathrm{G}$ & E. goniocalyx........... & 1911 & 16 & 1 & 6.7 & 21 & Crooked......... & Fair. \\
\hline $\mathrm{M}$ & E. goniocaly x.... & 1897 & 20 & 5 & 7.4 & 28 & Leaning, crooked & Scrubby. \\
\hline$A$ & E. ovata ................ & 1890 & 27 & 3 & 13.6 & 58 & Crooked.............. & Thrifty. \\
\hline G & 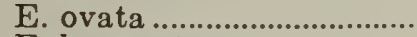 & 1911 & 16 & 1 & 5.8 & 42 & Forked top... & Thrifty. \\
\hline G & E. haemastoma............... & 1911 & 16 & 1 & 5.3 & 28 & Leaning........... & Fair. \\
\hline $\mathrm{G}$ & E. hemiphloia................... & 1911 & 16 & 4 & 5.4 & 32 & Forked.............. & Thrifty. \\
\hline A & E. leptophleba?................ & 1890 & 27 & 2 & 3.8 & 23 & Scrubby.......... & Poor. \\
\hline A & E. leu coxylon.......... & $1890 ?$ & $25+$ & 7 & 13.5 & 49 & Branching...... & Thrifty. \\
\hline A & E. linearis.......... & 1890 & $27-$ & 1 & 3.3 & 15 & Small............. & Scrubby. \\
\hline G & E. longifolia... & 1911 & 16 & 2 & 7.4 & 38 & Straight... & Thrifty. \\
\hline A & E. macrorrhyncha............. & 1890 & 27 & 1 & 12.1 & 40 & Crooked...... & Thrifty. \\
\hline G & E. McArthurii................... & 1911 & 16 & 1 & 5.6 & 42 & Crooked......... & Thrifty. \\
\hline A & E. marginata...................... & 1890 & 27 & 1 & 5.3 & 13 & Crooked............ & Scrubby. \\
\hline G & E. megacarpa...................... & 1911 & 16 & 1 & 2.3 & 20 & Forked top.... & Fair. \\
\hline $\bar{M}$ & E. melanophloia.................... & 1897 & 20 & 2 & 5.9 & 38 & Forked top..... & Fair. \\
\hline A & E. melliodora.................... & 1890 & 27 & 4 & 13.9 & 56 & Crooked.......... & Fair. \\
\hline $\mathrm{G}$ & E. melliodora.......................... & 1911 & 16 & 1 & 9.1 & 40 & Forked. & Thrifty. \\
\hline M & 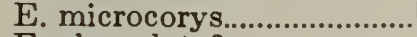 & 1897 & 20 & 4 & 7.4 & 26 & Crooked......... & Poor. \\
\hline A & E. obcordata?... & 1890 & 27 & 1 & 7.3 & 38 & Crooked.. & Poor. \\
\hline G & 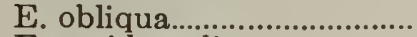 & 1911 & 16 & 1 & 7.3 & 30 & Straight........... & Thrifty. \\
\hline A & E. occidentalis.... & 1890 & 27 & 2 & 8.8 & 21 & Crooked........... & Thrifty. \\
\hline G & E. occidentalis.................. & 1911 & 16 & 2 & 4.1 & 16 & Crooked............. & Fair. \\
\hline $\mathbf{A}$ & E. paniculata.................... & 1890 & 27 & 2 & 9.0 & 49 & Fair. & Thrifty. \\
\hline $\mathrm{H}$ & E. paniculata.................... & ? & $20 \pm$ & 16 & 6.8 & 40 & Crooked.. & Thrifty. \\
\hline $\bar{M}$ & 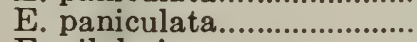 & 1897 & 20 & 4 & 7.0 & 34 & Crooked.......... & Fair. \\
\hline G & E. pilularis...... & 1911 & 16 & 2 & 3.6 & 24 & Broken tops.. & Fair. \\
\hline A & 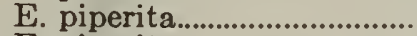 & 1890 & 27 & 1 & 19.1 & 54 & Straight............ & Good. \\
\hline G & 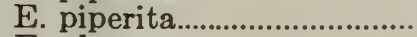 & 1911 & 16 & 1 & 6.8 & 24 & Forked top....... & Thrifty. \\
\hline A & 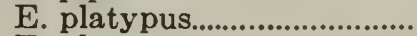 & 1890 & 27 & 1 & 1.4 & 10 & Scrubby.............. & Good. \\
\hline G & E. platypus.......................... & 1911 & 16 & 1 & 2.2 & 14 & Scrubby.......... & Good. \\
\hline $\mathrm{A}$ & E. polyanthemos.............. & 1890 & 27 & 6 & 12.8 & 45 & Branching.......... & Thrifty. \\
\hline $\mathrm{M}$ & E. polyanthemos............. & 1897 & 20 & 12 & 6.5 & 34 & Branching........ & Thrifty. \\
\hline G & E. pulverulenta ................. & 1911 & 16 & 1 & 7.4 & 21 & Crooked........... & Thrifty. \\
\hline A & E. punctata.............. & 1897 & 27 & 1. & 15.4 & 51 & Spreading top.... & Thrifty. \\
\hline G & E. punctata grandiflora...... & 1911 & 16 & 2 & 5.3 & 26 & Forked.................. & Good. \\
\hline A & E. resinifera........................ & 1890 & 27 & 1 & 8.3 & 37 & Straight................. & Good. \\
\hline $\mathrm{C}$ & E. resinifera........................ & $1897 \pm$ & $20 ?$ & 25 & 7.0 & 45 & Straight.............. & Thrifty. \\
\hline A & E. rostrata.......................... & 1890 & 27 & 5 & 14.6 & 68 & Crooked............. & Thrifty. \\
\hline $\mathrm{M}$ & E. rostrata.. & 1897 & 20 & 10 & 6.2 & 35 & Crooked............ & Thrifty. \\
\hline $\mathrm{C}$ & E. saligna......................... & $1897 ?$ & $20 \pm$ & 3 & 9.2 & 57 & Straight... & Thrifty. \\
\hline $\bar{A}$ & E. sideroxylon rosea....... & 1890 & 27 & 4 & 19.5 & 45 & Crooked............ & Thrifty. \\
\hline M & E. sideroxylon rosea........... & 1897 & 20 & 5 & 6.5 & 43 & Crooked.. & Fair. \\
\hline A & 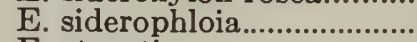 & 1890 & 27 & 4 & 11.5 & 67 & Straight.............. & Thrifty. \\
\hline M & E. stuartiana....................... & 1897 & 20 & 2 & 5.1 & 26 & Crooked............. & Fair. \\
\hline A & E. tereticornis....................... & 1890 & 27 & 1 & 17.9 & 96 & Straight............. & Excellen \\
\hline $\mathrm{M}$ & E. tereticornis...................... & 1897 & 20 & 2 & 10.1 & 43 & Straight............... & Good. \\
\hline A & E. viminalis......................... & 1890 & 27 & 2 & 16.8 & 54 & Straight................. & Thrifty. \\
\hline C & E. viminalis....................... & $1897 ?$ & $20 \pm$ & 10 & 12.7 & 60 & Straight............... & Thrifty. \\
\hline $\mathbf{M}$ & E. viminalis... & 1897 & 20 & 1 & 3.9 & 44 & Fair......................... & Fair. \\
\hline
\end{tabular}


In height growth there is a somewhat different grouping of leading species as follows:

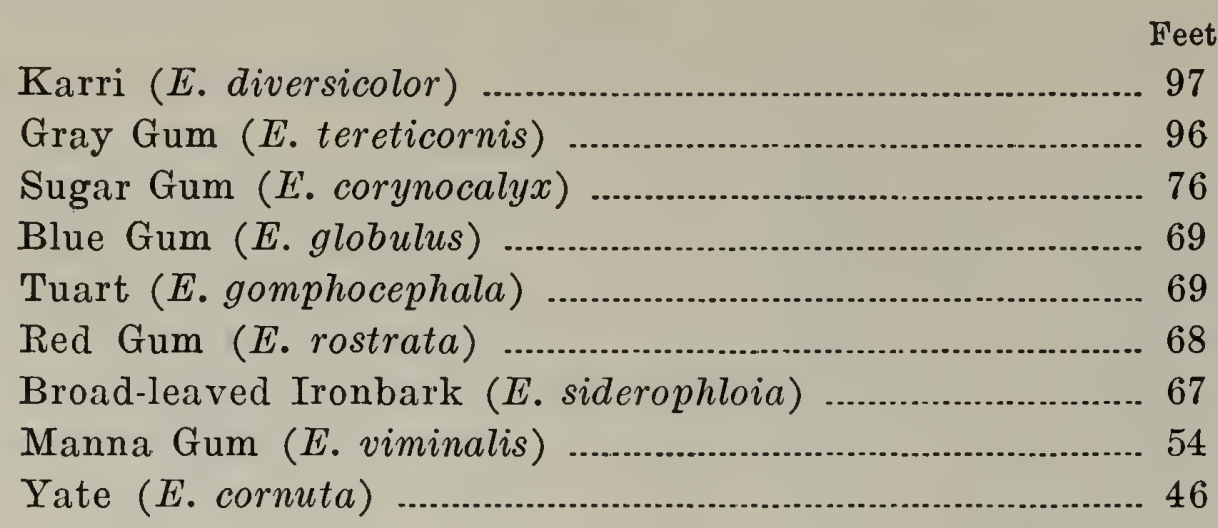

Several of the less important species averaged between 50 and 60 feet in height, but were far down the list in diameter growth. Three species not previously discussed show up well in the above list, these being Yate, Tuart and Broad-leaved Ironbark. The last is a tropical species of medium size which grows only in northern New South Wales and Queensland and does not appear to be of much commercial importance there. At Santa Monica it is vigorous and grows much straighter than many species. Yate (E. cornuta) and Tuart (E.gomphocephala) are the two hardest and strongest Australian woods and are highly valued for purposes requiring such properties. They are confined to narrow areas near Perth in Western Australia where, on account of their value and comparative scarcity, the state government has restricted their exportation. At Santa Monica the Tuart is straight and tall, but has a much branched and somewhat flattened crown while the Yate has a crooked habit of growth and makes relatively slow growth in height. The fruits of $E$. cornuta and of its variety (lehmannii) occur in dense clustered heads and give the trees an unique and interesting decorative appearance. A Yate tree on the campus at Berkeley is thriving but has a short and crooked trunk.

Table 8 summarizes the growth of twenty-two species planted at Santa Monica in 1901 in rows, using a 7 by 7 foot spacing throughout. It will be noted that Blue Gum and Sugar Gum are the outstanding trees in this tabulation though several others have made very satisfactory growth and were thriving when examined.

\section{Arboretum Plantation at Del Rosa, San Bernardino County.}

In 1911 the U. S. Forest Service started an arboretum of Eucalyptus species by setting out about thirty varieties in a plot adjacent to the nursery at the Del Rosa Ranger Station. 'The spacing throughout was 12 by 12 feet and nine trees of each species were planted. 
Experimental work with Eucalyptus was discontinued by the Forest Service shortly after this and the arboretum was never enlarged. It is situated in the dry foothills of the Angeles National Forest on coarse, granitic soil which is very pervious to moisture. The mean annual rainfall is about 15 inches, very high temperatures are the rule in summer and the site may be considered typical of the arid foothill areas surrounding the irrigated citrus orchards of San Bernardino

TABLE 8

Mixed Eucalyptus Plantation, Santa Monica Forestry Station, Los Angeles Countr, Age 16 Years

\begin{tabular}{|c|c|c|c|c|c|c|}
\hline Number & Species & $\begin{array}{l}\text { Number } \\
\text { planted }\end{array}$ & $\begin{array}{l}\text { Per cent } \\
\text { survival }\end{array}$ & $\begin{array}{l}\text { Average } \\
\text { d. b. h. }\end{array}$ & $\begin{array}{c}\text { Average } \\
\text { height }\end{array}$ & Remarks \\
\hline C 5 & E. sideroxylon..... & 10 & 70 & 7.5 & 41 & Crooked, fair. \\
\hline C 8 & E. globulus................... & 10 & 40 & 11.9 & 66 & Thrifty. \\
\hline C 9 & E. pulverulenta. & 10 & 40 & 5.9 & 32 & All crooked. \\
\hline C 10 & E. viminalis..... & 10 & 40 & 8.5 & 49 & Thrifty. \\
\hline C 11 & E. pellita ................................ & 10 & 60 & 5.9 & 44 & Poor, tops dying. \\
\hline C 12 & 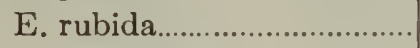 & 10 & 10 & 6.1 & 40 & Fair. \\
\hline C 13 & E. corynocaly $\mathrm{x} . . . . . . . .$. & 10 & 100 & 10.1 & 61 & Good. \\
\hline C 15 & E. McArthurii........ & 10 & 60 & 9.7 & 40 & Fair. \\
\hline C 16 & E. stricta .......... & 10 & 40 & 2.4 & 14 & Scrubby. \\
\hline C 1 & E. vıminalis? ..... & 8 & 37 & 7.8 & 45 & Good. \\
\hline C 2 and 4 & E. rostrata............... & 8 & 75 & 6.2 & 35 & Crooked, fair. \\
\hline C 3 & E. botryoides........................ & 8 & 37 & 3.3 & 25 & Scrubby. \\
\hline C 5 & E. maculata..................... & 8 & 100 & 5.8 & 34 & Thrifty. \\
\hline C 6 and 11 & E. sideroxylon rosea.. & 8 & 87 & 8.5 & 43 & Fair-good. \\
\hline C 8 & 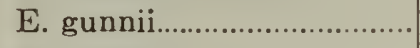 & 8 & 75 & 3.5 & 29 & Suppressed by others. \\
\hline C 9 & 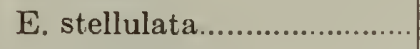 & 6 & 83 & 7.3 & 51. & Good. \\
\hline C 10 & E. meiliodora? ...................... & 8 & 83 & 6.4 & 39 & Forked, crooked. \\
\hline C 12 & E. raveretiana................... & 8 & 62 & 2.8 & 23 & Scrubby. \\
\hline C 13 & E. occidentalis.................... & 8 & 62 & 4.0 & 29 & Scrubby. \\
\hline C 14 & 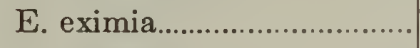 & 9 & 44 & 5.6 & 27 & Scrubby. \\
\hline C 15 & E. robusta....................... & 8 & 75 & 8.9 & 41 & Good. \\
\hline C 16 & 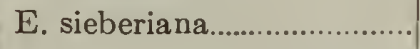 & 8 & 25 & 6.1 & 35 & Fair. \\
\hline
\end{tabular}

The spacing in this plantation was 7 by 7 feet throughout. Each species was planted in a row by itself. The slower growing or naturally small species such as $E$. gunnii, $E$. eximia and $E$. sieberiana were badly suppressed by larger and more rapid growing species.

and adjacent counties. The effects of drought were noticeable in the appearance of most of the trees and many of them showed that they had been more or less severely injured by frost. All of these trees, as well as the adjacent plantations, were destroyed by a forest fire in the fall of 1922. A summary of measurements made in 1920 is given in Table 9.

A large number of Eucalyptus species were planted at different times at the Chico Forestry Station in Butte County, but in many cases frost damage has been so severe and so frequent that only the 
hardier varieties have reached any considerable size. The results of measurements of the best trees are given in Table 10. Only Blue Gum, Manna Gum and Messmate Stringybark are fully at home here. Other species which persist in scrubby form include $E$. corynocalyx,

\section{TABLE 9}

Mixed Eucalyptus Plantation at Del Rosa Station, San Bernardino County, Age 9 Years

(Examined March, 1920)

\begin{tabular}{|c|c|c|c|c|c|}
\hline $\begin{array}{c}\text { Plot } \\
\text { Number }\end{array}$ & Species & $\begin{array}{l}\text { Per cent } \\
\text { survival }\end{array}$ & $\begin{array}{l}\text { Average } \\
\text { d. b. h. }\end{array}$ & $\begin{array}{c}\text { Average } \\
\text { height }\end{array}$ & Condition \\
\hline 1 & E. tereticornis (Cooper).. & 100 & 4.7 & 34 & Good. \\
\hline 2 & E. tereticornis........................... & 100 & 4.6 & 31 & $33 \%$ Doubles. \\
\hline 3 & 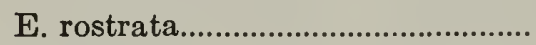 & 89 & 5.2 & 36 & Crooked and forked. \\
\hline 4 & 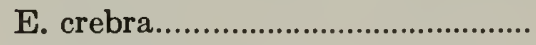 & 33 & 2.8 & 33 & Poor form. \\
\hline 5 & 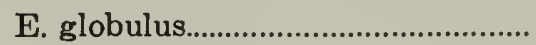 & 44 & 5.6 & 37 & Good. \\
\hline 6 & E. polyanthemos................................. & 78 & 3.4 & 25 & Good. \\
\hline 7 & E. coriacea & 11 & 5.3 & 33 & Forked. \\
\hline 8 & 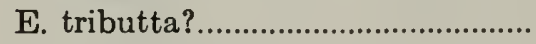 & 33 & 5.0 & 30 & Crooked, leaning. \\
\hline 9 & 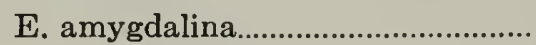 & 11. & 3.0 & 20 & Scrubby. \\
\hline 10 & 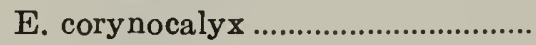 & 100 & 5.3 & 41 & Thrifty. \\
\hline 11 & 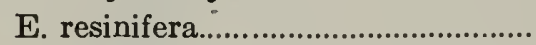 & 55 & 3.3 & 24 & Crooked, scrubby. \\
\hline 12 & E. regnans.............................................. & 55 & 2.6 & 21 & Poor. \\
\hline 13 & 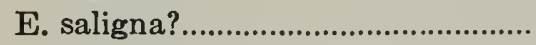 & 78 & 4.3 & 24 & Crooked, frosted. \\
\hline 14 & 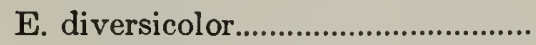 & 100 & 4.3 & 31 & Fair. \\
\hline 15 & E. longifolia........................................... & 100 & 3.2 & 25 & Fair. \\
\hline 16 & 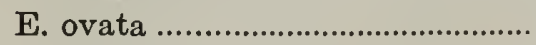 & 89 & 3.8 & 28 & Crooked, leaning. \\
\hline 17 & 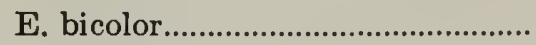 & 78 & 2.9 & 21 & Crooked, scrubby. \\
\hline 18 & 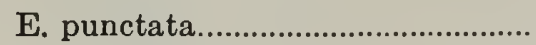 & 78 & 3.7 & 27 & Fair. \\
\hline 19 & 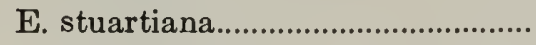 & 0 & 0 & 0 & \\
\hline 20 & 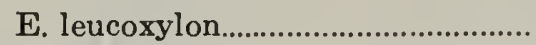 & 22 & 3.8 & 28 & Crooked, forked. \\
\hline 21 & 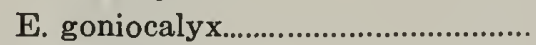 & 100 & 4.0 & 24 & Forked, crooked. \\
\hline 22 & 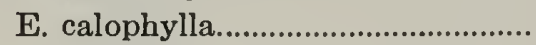 & 55 & 2.6 & 15 & Scrubby. \\
\hline 23 & 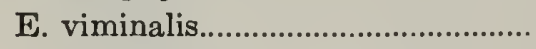 & 78 & 4.9 & 35 & Crooked, leaning. \\
\hline 24 & E. corymbosa........................................ & 22 & 1.9 & 16 & Scrubby. \\
\hline 25 & E. sideroxylon........................................ & 55 & 5.6 & 37 & Fair. \\
\hline 26 & 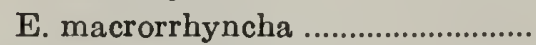 & 33 & 4.7 & 34 & Crooked. \\
\hline 27 & 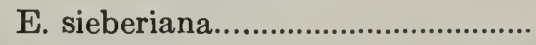 & 0 & 0 & 0 & \\
\hline 28 & E. robusta.......................................... & 55 & 3.2 & 22 & Fair. \\
\hline 29 & 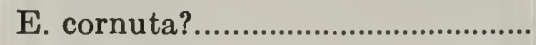 & 33 & 3.0 & 23 & Scrubby. \\
\hline 30 & 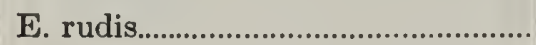 & 22 & 2.0 & 21 & Forked scrubs. \\
\hline
\end{tabular}

Trees were planted March, 1911. Spacing 12 by 12 feet. Nine trees of each species were planted. Examination made March, 1920. Many showed evidence of frost and drought damage. In numbers 8, 13, and 29 there is some doubt as to the species. The trees are not well enough developed to make exact identification possible.

E. botryoides, E. diversicolor, E. leucoxylon and E. punctata. Several other species though still alive have been so badly damaged that exact identification is impossible. The splendid growth of Manna Gum is the outstanding feature of all Eucalyptus trees planted at this station. It is possible that the tree here given as $E$. amygdalina may prove to be a specimen of $E$. regnans as the two species are very much alike. 


\section{UTILIZATION}

Fuel.-The principal use to which the wood of Eucalypts grown in California has been put is fuel. Eucalyptus wood burns brightly and imparts a delightful fragrance to the house when burned in an open fireplace. Different species vary somewhat in fuel value, but

TABLE 10

Growth of Specimen Eucalypts, Chico Forestry Station, Butte County

\begin{tabular}{|c|c|c|c|c|c|c|}
\hline $\begin{array}{c}\text { Plot } \\
\text { Number }\end{array}$ & Species & $\begin{array}{c}\text { Age } \\
\text { years }\end{array}$ & $\begin{array}{c}\text { Number } \\
\text { trees }\end{array}$ & d. b. h. & Height & Form \\
\hline 46 & Eucalyptus globulus........ & $30 \pm$ & 3 & 17.3 & 100 & Good. \\
\hline 47 & Eucalyptus obliqua..... & $30 \pm$ & 3 & 13.5 & 63 & Good. \\
\hline 48 & Eucalyptus viminalis.... & $30 \pm$ & 19 & 29.9 & 100 & Excellent. \\
\hline 36 & Eucalyptus amygdalina. & $25 \pm$ & 1 & 19.4 & 36 & Crooked; severely frosted 1913. \\
\hline 44 & Eucalyptus linearis ......... & $25 \pm$ & 2 & 13.1 & 60 & Crooked; severely frosted 1913. \\
\hline
\end{tabular}

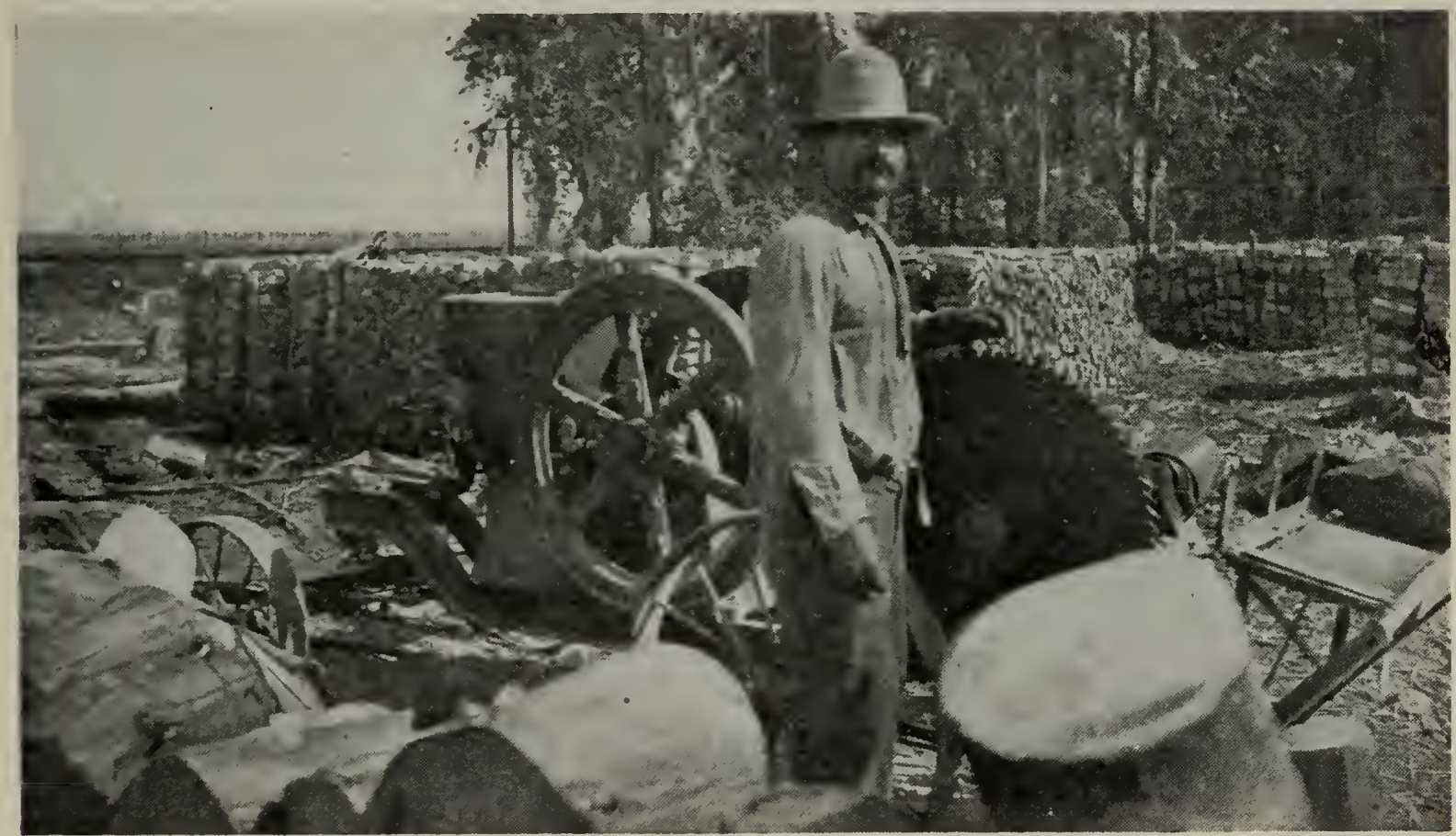

Fig. 22.-A gasoline engine saw outfit cutting 12-inch cordwood from a Blue Gum grove 15 years old, near Sanger, Fresno County. The crew of three men can cut $7 \frac{1}{2}$ cords a day at a cost of about $\$ 8.00$ a cord for felling, sawing and stacking. The wood sells for $\$ 14.00$ to $\$ 16.00$ a cord at the grove.

all of those grown extensively in California are practically equal to live oak and much better than most other native fuel woods. Eucalyptus wood should be split into the desired sizes while green as it becomes so tough, when fully seasoned, that splitting is very difficult and expensive. Trees for fuel should not be too large and the best age for this purpose is about ten or twelve years. Very large trees are so expensive to saw and split that contractors do not wish to 
handle them. In the case of smaller trees, sawing can be easily done with a small portable saw and over half of the stems can be used "in the round," i.e., without splitting.

In the aggregate, a great deal of Eucalyptus wood is being used for fuel, the stumpage value of plantations being cut for this purpose varying with locality and market conditions from $\$ 1.50$ to $\$ 4.00$ a cord. Grove owners can have wood cut and stacked on contract for $\$ 8.00$ to $\$ 12.00$ per cord (12 to 16 inch stove-wood) and the price obtained per cord for wood of this kind stacked in the grove varied from $\$ 10.00$ to

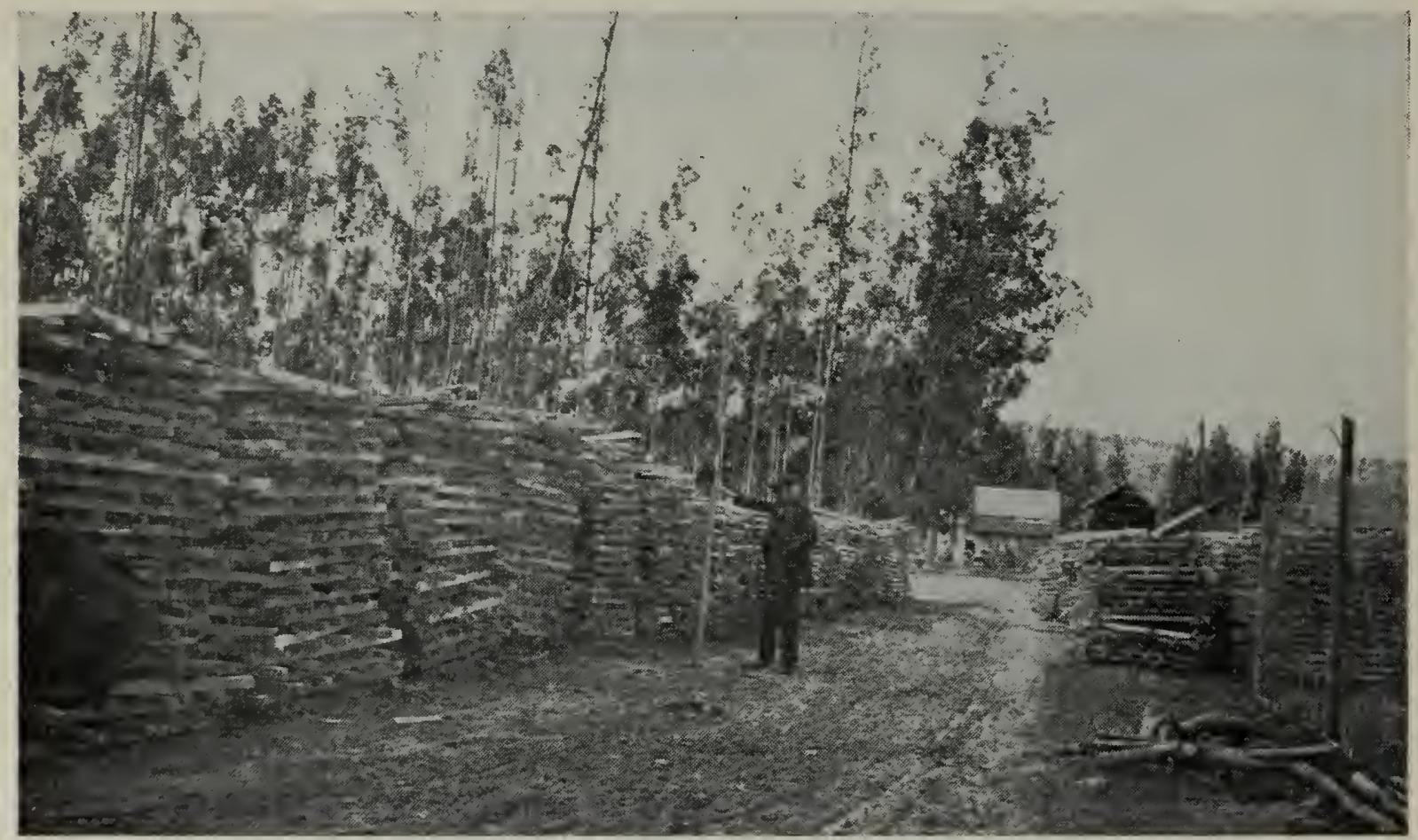

Fig. 23.-These pieces of Blue Gum are 17/8 inches square by 6 feet long, cut from a grove at Stony Point, Sonoma County. Blue Gum is suitable for the manufacture of insulator pins and other small turned articles. After being seasoned for six to eight weeks in open piles these blanks are turned into insulator pins, the product averaging about 2500 pins a cord. A stumpage price of $\$ 4.50$ a cord has been paid for 25-year-old groves used for this purpose.

$\$ 16.00$ in 1923. Eucalyptus wood delivered to users in California towns and cities costs from $\$ 18.00$ to $\$ 24.00$ a cord, the advance over the grove price resulting from transportation and yard storage costs. In many parts of the state Eucalyptus wood is sold in competition with native fuel woods and the stumpage value must be decreased accordingly if the wood is to be handled at all. For this reason a good deal of Eucalyptus stumpage has been sold at about $\$ 1.00$ a cord and many contractors say that it cannot be handled at a profit if it costs more than this. Some groves are situated in places so remote from transportation or a market that the standing trees have practically no value for fuel purposes. 
Charcoal.-Eucalyptus wood produces an excellent grade of charcoal, probably better than that from most native California woods. When produced in open earth kilns, about 1000 pounds of charcoal per cord of wood is secured and the burning of a kiln takes about three weeks (fig. 24). During this time it must be under almost constant observation so that the fire will not break through the kiln and destroy the wood entirely. Although there is a good market for charcoal, this process of manufacture has been so expensive that makers of charcoal have been unable to pay a much greater stumpage price for Eucalyptus wood than it commands for fuel purposes. It seems probable that an

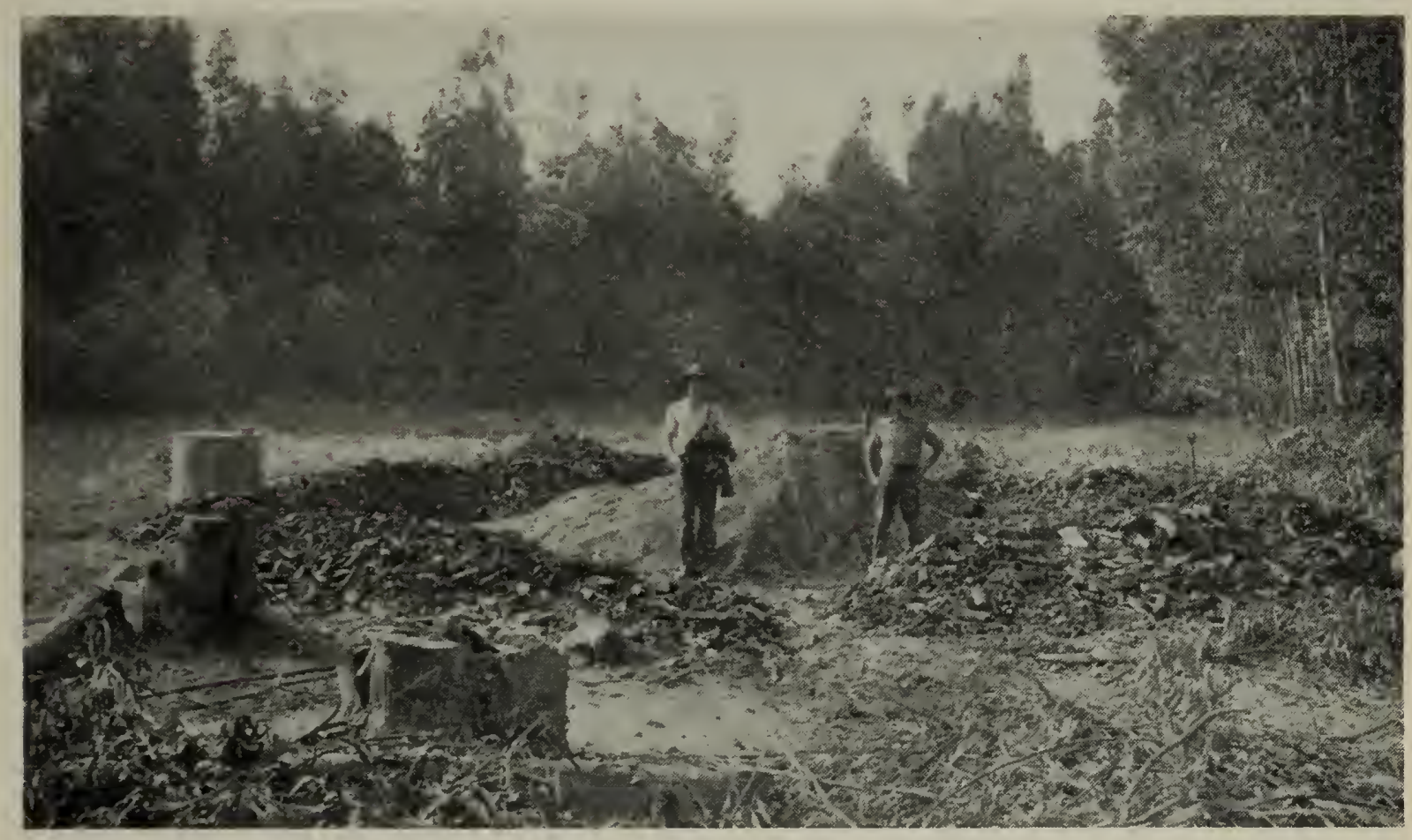

Fig. 24.-A pile of chareoal from 25 cords of Eucalyptus wood burned in an earth kiln for 21 days. When handled in this way it produces about 1000 pounds of charcoal a cord.

increasing demand for charcoal may make the erection of retorts for charcoal production feasible. These operate with much greater efficiency and should make it possible for producers to pay a somewhat higher stumpage price for the trees.

Insulator Pins made from California grown Blue Gum have been used for several years by power companies and have proved to be very satisfactory. One firm is manufacturing about 125,000 pins a year from a 25-year-old Blue Gum grove in Sonoma County (fig. 23). The stumpage value of trees for this purpose is about the same as for fuel wood. The trees are sawn into billets, 1\%/8 inches square by 6 feet in length and stacked in open piles in a shady place out of doors for about six weeks to season. They are then taken to the turning machines 
and made into the finished product. The small squares used in this operation do not seem to check or warp unduly, as is usually the case when pieces of larger size are sawn, and the losses due to such defects are not unduly large. The pins are strong and sufficiently durable to compare very favorably with high grade locust pins.

Lumber.-Very little lumber has been made from California Eucalyptus trees except in an experimental way. Most of the experiments have been disappointing because of excessive checking and warping of the boards during seasoning. This checking and warping is the most serious obstacle in the utilization of California grown Eucalyptus of all species. In spite of the hardness of the wood and its interlocking fibres, logs cut from trees 10 to 15 years old will often split open from end to end after lying on the ground only a few weeks. Lumber frequently has become so deformed during seasoning that its original dimensions could scarcely be determined and the losses in volume have usually amounted to about 50 per cent of the original volume. Very probably this is due in large part to the extreme youth of the trees which in spite of their size, are almost entirely made up of sapwood. In Australia, Eucalyptus lumber is sawn from virgin forest trees which are of unknown age, probably several hundred years old. It may be that as California trees increase in age, the wood will be less difficult to handle and may produce satisfactory lumber.

Mr. J. T. Gillespie of San Jose was for several years engaged in the manufacture of lumber from large Blue Gum trees cut in that vicinity. The trees were mostly large, open-grown specimens over 35 years of age, and although there was considerable loss in volume due to warping and checking, it was not nearly so great as has been the rule with younger trees. These so-called "San Jose Blue Gums" were probably grown from seed collected by Bishop Taylor in Victoria* or New South Wales while much of the other Blue Gum in the state was raised from Tasmanian seed, and Mr. H. D. Tiemann of the U. S. Forest Service found during the course of dry kiln experiments carried on at Berkeley (1912-14), that the wood was of decidedly better quality than that produced by other California grown trees. Whether this is due to a varietal difference in the trees, to their greater age, or to the favorable site conditions under which they grew at San Jose, has not been determined. Mr. Gillespie said that there was considerable variation in the straightness of grain and quality of wood between individual trees and that checking and warping were much worse in

* Mr. Tiemann confirmed the visit of Bishop Taylor to Sydney and noted that Victorian Blue Gum trees have smaller capsules and more scaly bark than the Tasmanian trees. 
some. He also claimed that the time of year when the trees were cut had considerable influence on the amount of checking in the product. The lumber manufactured by him was seasoned in open sheds for about two years before remanufacture and proved to be very satisfactory for plow beams, wagon tongues and beds, hay-rake frames and teeth, and for other purposes where strength and hardness are required. A few pieces of furniture were made experimentally and were reasonably satisfactory, while some very good veneer was also produced in a small way. During several years the Gillespie plant turned out a large number of insulator pins annually but their manufacture was discontinued because of low prices induced by competition of other species and manufacturers.

Miscellaneous Uses.-The wood of California grown Eucalypts has been used experimentally for toy parts, tool handles, paving blocks, posts, piles and piling, but the severe checking and inability to hold its form, coupled with the fact that the wood of young trees is not durable when in contact with the soil, has prevented very widespread use for these purposes. Species other than Blue Gum have grown so slowly that few trees have reached a size large enough to be cut for anything except firewood. Experiments with untreated Blue Gum piles in salt water have shown that it is but little more resistant to teredo attack than Douglas Fir or other native species commonly used for piling.

Blue Gum and Manna Gum have been used for several years for piling and rip-rap work along the Santa Ana River in Orange County, but have not proven very durable in the moist soil along the river banks. Blue Gum piles were used in the construction of a long causeway on the State Highway between Ventura and Santa Barbara in 1911. Most of these were driven in the sand along several miles of ocean front and in this situation have given very good service. Sugar Gum, Gray Gum and Red Gum are all more durable in the soil than Blue Gum, but Red Gum is usually too crooked to make a satisfactory pile and the other species have not been available in sufficient quantities to warrant the working up of a market for them. Sugar Gum was the most durable of twelve species tested at the Santa Monica Forestry Station as fence posts. The best posts were those split from trees 12 to 14 inches in diameter in which the heartwood was sound after seven years in the ground but the sap wood had entirely rotted away. Posts made from small trees of any of the species are mostly sapwood and therefore very unsatisfactory, as they rot quickly and may usually be easily pushed over after two to three years. 
Eucalyptus Oil.--The United States imports annually from Australia about 150,000 pounds of Eucalyptus oil, worth about $\$ 75,000$. This imported oil is made by distilling mixed lots of leaves of a number of Australian species, most of which are not present in California. The leaves of these species contain much larger quantities of oil than those commonly planted in this country, and the oil is richer in certain essential constituents. A number of attempts have been made to produce a satisfactory oil from California grown trees, but apparently the California oil cannot be refined to meet the U. S. pharmacopoea

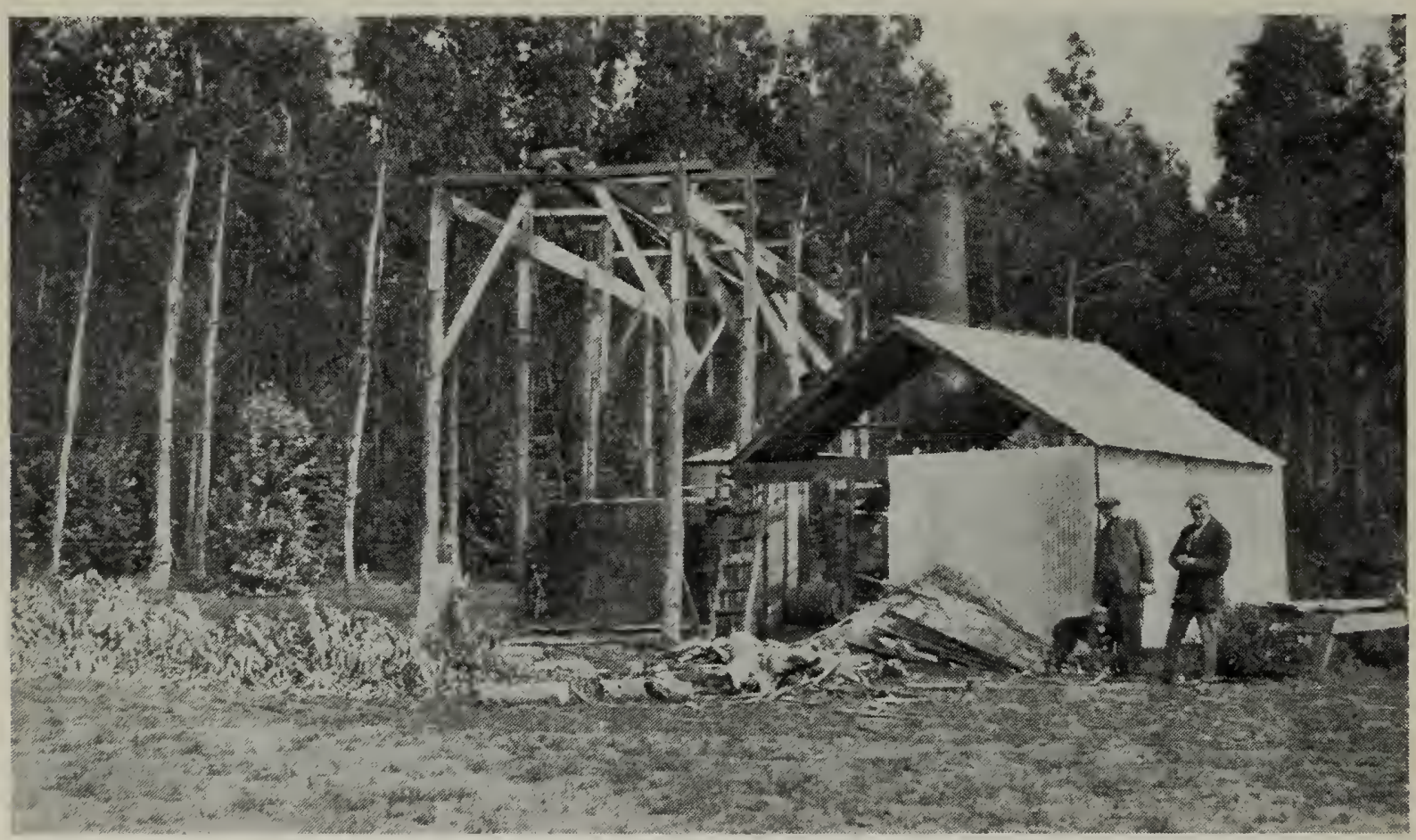

Fig. 25.-An experimental steam distillation plant near Guadalupe for distilling oil from Eucalyptus leaves. The cost of making oil from the foliage of thinned trees in 1920 was 60 cents a pound. The trees in the background are 13-year-old Blue Gums. The sprouts are two years old, from the stumps of trees cut in thinnings.

standard except at a prohibitive cost. Tests at the U. S. Forest Products Laboratory showed that oil from California Blue Gum trees could be made to meet the U. S. P. requirements by suitable fractional distillation; but this process entailed the loss of from 35 to 45 per cent of the crude oil.* The investigators felt that it might be possible with an efficient distillation plant, to obtain an oil that would meet the U. S. P. requirements without redistillation, by separating the crude oil into several fractions as it is distilled from the leaves. Up to the present time this has not been attempted, and it is doubtful if it

* Report by S. A. Mahood and D. E. Cable, "An Investigation of the Oil of Eucalyptus globulus." 
would be profitable, as the higher grade Australian oil can be laid down in this country at practically the same price as it costs to make the California crude oil.

The cost of producing crude oil at Guadalupe, San Luis Obispo County, from trees cut in thinning the Brintnall Ranch groves during 1921, was 60 to 65 cents a pound (fig. 25). The prices quoted on Australian oil at that time averaged about 10 cents a pound cheaper. Those in charge of the work felt sure that, in connection with clear cutting operations, the cost could be cut to approximately that of the Australian product. Even so the California oil would be at a disadvantage unless it can be made to meet the U. S. P. specifications. Up to the present time it has been used in only limited amounts in the manufacture of unofficial medical preparations, boiler compound, soap, and as a flotation oil. Further investigations are necessary to determine just what equipment and methods are required for the production of a high grade California oil at a minimum cost.

\section{Notes on Other Species}

Mr. H. D. Tiemann who carried on the seasoning experiments, mentioned above, has recently returned from Australia where he carried on seasoning experiments on the wood of mature trees, and was able to observe carefully the growth of a large number of Eucalyptus species under their natural condition, as well as methods of utilization in that country. He remarks in a recent letter, "The trouble with the California Eucalyptus is that almost invariably the wrong species have been planted," and later suggests that the following species are worthy of trial because of the value of their wood and their probable suitability to California conditions.

Woollybutt (E. delegatensis). Very hardy and stands freezing winters.

Jarrah (E. marginata).* Not frost hardy.

Spotted Gum (E. maculata).* Not frost hardy.

Ironbark (E. paniculata).*

White Stringybark (E. eugenioides).*

Flooded Gum or Sydney Blue Gum (E. saligna). Not frost hardy.

Victorian Mountain Ash (E. regnans).

Victorian Grey Box (E. hemiphloia).**

Those marked (*) in the above list have wood which is very hard and durable. The others produce lumber of good quality in Australia although it is not so hard nor so durable in contact with the soil. 
Woollybutt and Mountain Ash produce lumber which is excellent for general building, flooring, furniture and similar uses. The first of these is the most hardy of any Eucalyptus species in Australia.

Reference to the preceding tables will show that several of the suggested species have been planted in California on a small scale, but that their growth has been much slower than that of Blue Gum. The following observations may be made with regard to these species:

Jarrah (E. marginata).-There are probably not over two or three trees of this species growing in California. The one at Santa Monica is a scrub about fifteen feet high after 25 years of growth.

Woollybutt (E. delegatensis).-This species is not present in the collections at Santa Monica or Del Rosa, and is probably not growing any where in the state.

Spotted Gum (E. maculata).-This species and its variety, the Lemon-scented Gum (E. maculata citriodora) are beautiful ornamental trees and are growing as lawn specimens in several sections of the state (fig. 20). Spotted Gum has grown vigorously at Santa Monica, averaging 5.8 inches d.b.h. and 34 feet in height in 16 years, and its beautifully mottled bark makes it conspicuous among all of the associated trees. A beautiful group of Lemon-scented Gum is growing on the Ward estate in Santa Barbara, and a few of these trees have persisted in the foothill plantations on the Bixby Ranch in Orange County, but in the latter situation they have made very slow growth. A few trees of the species and of the variety are present in the San Francisco Bay region but neither is very frost hardy, although a Spotted Gum seedling survived the unusually cold weather during the winters of 1921 and 1922 in a sheltered spot in Berkeley, without injury.

Ironbark (E. paniculata).-Twenty-two trees of this species on the upper mesa at the Santa Monica station have made fair growth in diameter but have lagged in height growth. In the mixed planting, two trees 27 years old average 9 inches d.b.h. and 49 feet in height. Several trees on the driest site have died during periods of extreme drought. Elsewhere in the state this species is rare.

Flooded Gum (E. saligna) is a tree of upright habit and good form in California. Its growth at Livermore, Alameda County, and at Santa Monica, are shown in the tables. It will undoubtedly do well in frost free situations where adequate soil moisture is available.

White Stringybark (E. eugenioides).-The few trees of this species at Santa Monica are tall, straight and cylindrical; they have grown with moderate rapidity and seem well suited to the conditions. A single seedling in the experimental plot on the University campus at Berkeley has shown marked rapidity of growth, and has not been 
injured by frost during three winters. The species has narrow, slender leaves; yellow-brown, fibrous bark and a dark reddish tinge to its graceful foliage which makes it unusually ornamental.

Victorian Mountain Ash (E. regnans).-This species is probably not present in California unless the trees which have been planted under the name of $E$. amygdalina may be of this species. There has been a good deal of confusion in nomenclature of these trees even in Australia and it has not been possible to determine whether the California trees are really $E$. regnans, or the tree now known as $E$. amygdalina in Australia which goes under the common name of Peppermint. The trees observed in California at Santa Monica, Chico, and in San Benito County had all been more or less severely injured by frost and were of scrubby form in consequence. As the true E. regnans is quite frost hardy in Australia, the California trees are probably the other species, which is smaller and less satisfactory.

Victorian Grey Box (E. hemiphloia).-Very few trees of this species have been tried in California. Four trees are growing at Santa Monica which, though apparently thrifty, are crooked and have made indifferent growth in height.

All of the above species deserve further trial in California because of the high quality of their wood, but it seems certain that they will all grow more slowly than the species which have thus far been commonly planted. With the possible exception of $E$. delegatensis and $E$. regnans these species will not succeed except in comparatively frost free situations.

Mr. Tiemann in a recent letter makes the following comments on the species most commonly planted in California and urges further trial of the above mentioned more valuable trees.

Blue Gum (E. globulus).- "It makes excellent firewood and small articles such as insulator pins, but is not suitable for lumber at an age less than 75 to 100 years. It does not yield as good timber as many other species."

Red Gum (E. rostrata)._."A durable wood, but a tree of poor form."

Gray Gum (E. tereticornis)._- "Probably a better tree than rostrata on account of its better shape."

Manna Gum (E. viminalis).- "In Victoria it is a good sized tree but the lumber is certainly inferior. I would not consider it at all."

Messmate Stringybark (E. obliqua).- "It grows with regnans and in stunted form almost to the tree limit, where it endures severe cold and prolonged winters. The wood is certainly inferior as it is full of gum pockets." 


\section{SUMMARY}

Blue Gum makes the most rapid growth of any species of Eucalyptus thus far planted in California. It is best suited to the conditions obtaining near the coast but succeeds fairly well in the interior valleys and in southern California if adequate soil moisture is present. On the basis of 67 groves measured, the mean annual growth is 271 solid cubic feet per acre, which equals 3.02 standard cords. The highest volume growth recorded was in the case of an 8-year-old grove growing on very fertile silt swampy land in Alameda County. The spacing here was 5 by 5 feet, the trees averaging when measured 5.8 inches d.b.h. and 60 feet high, the mean annual growth had been 736 cubic feet or 8.17 standard cords per acre. The best grove has averaged between 450 and 550 cubic feet per acre per annum, while several growing on poor, sandy, exposed or dry sites have grown at a rate less than 90 cubic feet per acre per annum.

A tentative yield table for Blue Gum for good, medium and poor sites is given; the sites having been determined according to the height method. This shows the yields per acre of ten-year plantations on the three sites to be as follows:

Site I-6100 cu. ft., Site II-3400 cu. ft., Site III-2050 cu ft.

Groves of Red Gum and Gray Gum, two very similar species, have averaged about 100 cubic feet volume growth per acre per yearapproximately one standard cord. The Red Gum is unsatisfactory because of its crooked habit of growth. Both species are more drought resistant than Blue Gum and produce wood which is more durable in the soil.

Sugar Gum is very drought resistant but subject to injury by frost, and so is best suited to the climatic conditions of southern California. The 17 groves measured made an average mean annual growth of 110 cubic feet, or 1.22 cords per acre.

Individual trees of Manna Gum have made excellent growth in the Sacramento Valley region, but none of them are growing in plantations.

Figures on the growth of a large number of other species are given in tabular form. Some of these are growing in plantations while others are to be found in California only as individual specimens. The growth requirements and characteristics of several of the more important of these trees, when growing under Australian conditions, are 
given for comparison. The most valuable of these Australian species of Eucalyptus are apparently poorly suited to California conditions and will undoubtedly make slower volume growth than the species which have been so extensively planted.

The wood of California grown Eucalyptus has been used for fuel, charcoal, insulator pins and other small turned articles. Some lumber has been made experimentally but has not been satisfactory because of excessive checking and warping of the wood during seasoning. Oil has been distilled experimentally from the leaves but thus far, has not come up to the U. S. P. requirements. The value of standing Eucalyptus trees has varied from $\$ 1.00$ to about $\$ 4.00$ a cord, according to the location and character of the trees, and is about the same for fuel, charcoal or insulator pins.

\section{APPENDIX I}

\section{METHOD OF TAKING FIELD MEASUREMENTS}

Virtually all of the groves measured were planted according to a very accurately laid out rectangular system (usually the planting area wạs marked out into squares or rectangles after plowing) and in each sample grove, one or more rows running through representative portions were selected for measurement. The diameter breast high of each surviving tree in such rows was measured with a steel diameter tape and recorded in its proper place on the field sheet. All blank spaces or scrubby trees in the row were also recorded in their proper order, the total number of planting spaces being used to obtain the per centage of survival and therefrom the acre volume. Heights were measured with the Faustmann hypsometer, the observer standing a definite number of planting spaces distant from each tree as it was measured. Often it was impossible to measure the height of each tree for which a diameter measurement was taken, but enough heights were obtained to enable the drawing of a diameter-height curve for each grove from which the heights of the other trees was obtained. Frequently groves were visited in connection with work on other projects, ând because of insufficient time, the number of trees measured was unavoidably small. In groves of any considerable size an attempt was made to measure from seventy-five to one hundred trees.

As detailed a history as possible for each plantation was secured from the owner or from a resident of the locality. This included such points as: date of planting, replacement work, early cultivation and 
care. Where groves were being cut, data on character of product, cost of manufacture, cost of delivery, sale value of product and approximate yield per acre were secured.

The measurement of one or more rows through a plantation is believed to give a much better average of the grove as a whole than the measurement of one or more circular or rectangular sample plots. Because of the generally accurate rectangular spacing, the calculation of volume per acre by the sample row method is just as accurate and much more rapid than by the use of isolated sample plots. Also, if several soil or slope conditions are present in the plantation, it is possible to determine the influence of each by careful selection of rows to be measured.

\section{CALCULATION OF VOLUME}

As a basis for volume calculations in this study, a total of sixtyeight felled Eucalyptus globulus trees were measured in 1917 in a grove in Reidy Canyon, near Escondido, San Diego County. Taper measurements were made at 10 foot intervals along the stem of each tree with the diameter tape, and its solid cubic contents, including bark, down to 2 inches in the top were calculated by the Smalian method. The d.b.h. form factor* was then computed for each tree and the average form factor for each inch diameter class was obtained. No definite relation between diameter and form factor could be detected when the above values were plotted on cross section paper. Therefore the average form factor of the sixty-eight trees $(\mathrm{FF} .=.442)$ was used in all of the original calculations of volume.

Few opportunities for further taper measurements presented themselves until early in 1923, when an additional number of felled trees were measured. About the same time a set of old taper measurements of 23 Blue Gum trees was found in the files of the State Forester and used in the calculations. The total number thus available (123) covered a much wider range of diameter than the original sixty-eight trees and a definite decrease in ff. with increase in diameter was noted when the values were plotted. The curved average form factors of the 123 trees is shown in Table A.

* Form Factor (written ff.) is a decimal expressing the relation between the solid cubic contents of a tree and the contents of a cylinder of the same diameter and total height. The d.b.h. form factor method of obtaining volume is expressed as follows:

$\mathrm{V}=\mathrm{BH} \times \mathrm{ff}$. in which

$\mathrm{V}=$ volume of tree in cubic feet including bark.

$\mathrm{B}=$ square foot area of a circle of the same diameter as the breast.high measured.

$\mathrm{H}=$ total height of tree in feet.

$\mathrm{ff} .=$ form factor. 
TABLE A

Table of Form Factors for Eucalyptus Globulus

\begin{tabular}{c|c|c}
\hline d. b. h., inches & Form factor & $\begin{array}{c}\text { B. H. area f f. } \\
\text { for calculating volume }\end{array}$ \\
\hline 2 & .480 & 0.0105 \\
3 & .472 & 0.0232 \\
4 & .466 & 0.0406 \\
5 & .458 & 0.0623 \\
6 & .451 & 0.088 \\
7 & .444 & 0.118 \\
8 & .436 & 0.152 \\
9 & .428 & 0.189 \\
10 & .420 & 0.229 \\
11 & .413 & 0.272 \\
12 & .406 & 0.318 \\
13 & .400 & 0.369 \\
14 & .393 & 0.420 \\
15 & .388 & 0.476 \\
16 & .381 & 0.532 \\
17 & .374 & 0.590 \\
18 & .368 & 0.650 \\
19 & .361 & 0.710 \\
20 & .354 & 0.775 \\
21 & .347 & 0.835 \\
22 & .340 & 0.916 \\
23 & .333 & 0.965 \\
24 & .325 & 1.022 \\
25 & .318 & 1.083 \\
26 & .311 & 1.148 \\
27 & .303 & 1.206 \\
28 & .294 & 1.258 \\
29 & .288 & 1.320 \\
30 & .280 & 1.424 \\
\hline
\end{tabular}

Based on taper measurements at $10 \mathrm{ft}$. intervals, of 123 felled trees. Stumps average $1 \mathrm{ft}$. in height not included. Volume computed down to $2 \mathrm{in}$. at the top including bark.

$$
\text { Form factor }=\frac{\text { Vol. of stem }}{\text { Breast ht. area } \times \text { total ht. }}
$$

Column three is given for convenience in computing volumes. After d.b.h. and height have been measured, it is only necessary to multiply the figure given in this column opposite the d.b.h. class by the total height in order to obtain the volume in cubic feet. As this is an average figure, it should not be considered accurate for single trees.

Inasmuch as virtually all of the computation work had been completed with the use of the flat average ff. .442 for all diameters before the above additional data were available, it was necessary to make percentage corrections of volume per acre based on the average diameter of trees in each grove. . No correction was made for groves averaging 7 inches in diameter, but for those which averaged over or under 7 inches d.b.h. the volume per acre was lowered or raised according to the relation the ff. shown in Table 1 bore to the ff. .442. For 
example, the volume of a grove averaging 4 inches d.b.h. was increased 5.3 per cent, while the volume of a grove averaging 10 inches was decreased 5 per cent. In a majority of cases the percentage changes were so small as to make only a very slight difference in the total cubic foot volume per acre, and practically no change in the calculated mean annual growth per acre. While some objection may be raised against the use of this procedure on mathematical grounds, it was the only method possible without repeating a prohibitively large amount of calculative work, and it is felt that no appreciable error has been introduced by the use of these percentage corrections.

\section{APPENDIX II}

\section{SITE CLASSIFICATION-Eucalyptus globulus}

In order to arrive at a somewhat more exact estimate of the quality of various localities for growing Blue Gum, the various groves of this species have been separated into three site classes according to the height method, the procedure being as follows:

(1) Enough of the tallest trees to make 10 per cent of the number measured in each grove were averaged and the points plotted on cross section paper using height over age. Some groves in which overcrowding had interfered with height growth, were omitted from the calculations and a number of groves measured by L. Margolin* in 1910 were included. In all 71 groves were used.

(2) An average age-height curve was drawn, and maximum and minimum age-height curves were drawn to harmonize with the average. The zone between the maximum and minimum curves was then arbitrarily divided into three zones by similarly harmonized curves. These three zones are called Sites I, II, and III, or Good, Medium, and Poor. The site classification for each grove is indicated by the zone within which its age-height point, as plotted, falls.

(3) The cubic foot volumes per acre for all of the groves in each site class were plotted, using volume over age, and the points smoothed off by a curve, thus showing the average volume per acre.

The following table shows the values read from the harmonized curves in (2) above:

* Yiold from Eucalyptus Plantations in California. Bull. 1, State Board of Forestry, 1910. 
TABLE B

Site Classification-Eucalyptus globulus

Height Method

Based on measurement of 71 California plantations

\begin{tabular}{c|c|c|c|c}
\hline \hline \multirow{2}{*}{ Age, years } & $\begin{array}{c}\text { Herage height } \\
\text { 10\% best trees }\end{array}$ & \multicolumn{3}{|c}{ Heights } \\
\cline { 3 - 5 } & Site III below & Site II & Site I above \\
\cline { 2 - 5 } & Feet & Feet & Feet & Feet \\
10 & 46.5 & 41 & $41-53$ & 53 \\
15 & 78.5 & 70 & $70-90$ & 90 \\
20 & 103.0 & 92 & $92-119$ & 119 \\
25 & 114.0 & 102 & $102-133$ & 133 \\
30 & 121.0 & 108 & $108-139$ & 139 \\
& 125.5 & 112 & $112-145$ & 145 \\
\hline
\end{tabular}

When classified according to this method, the 71 groves used in the calculations appear in the following proportions :

$$
\begin{aligned}
& \text { Site I, } 19.7 \% \\
& \text { Site II, } 42.2 \% \\
& \text { Site III, } 38.1 \%
\end{aligned}
$$

The groves in each site class were grouped as follows for plotting of volume over age. Margolin's volume figures were not included because the form factor used in his calculations was not stated.

\section{TABLE C}

\begin{tabular}{|c|c|c|c|}
\hline Age class & Number of groves & Average age & Average volume, $\mathrm{cu} . \mathrm{ft}$. \\
\hline Years & & Years & \\
\hline 6 & 1 & 6 & 1,000 \\
\hline 7 & 2 & 7 & 3,030 \\
\hline 8 & 1 & 8 & 5,889 \\
\hline 11 & 1 & 11 & 6,690 \\
\hline 23 & 1 & 23 & 12,585 \\
\hline 36 & 1 & $361 / 2$ & 17,700 \\
\hline \multicolumn{4}{|c|}{ SITE II } \\
\hline Years & & Years & \\
\hline 2 & 1 & 2 & 103 \\
\hline 4 & 1 & 4 & 850 \\
\hline 6 & 4 & 5.6 & 1,020 \\
\hline 7 & 6 & 7 & 1,750 \\
\hline 8 & 3 & 8.1 & 2,686 \\
\hline 10 & 3 & 9.6 & 3,038 \\
\hline 11 & 1 & 11 & 5,012 \\
\hline
\end{tabular}

Grouping of Eucalyptus globulus Groves for Yield Caldulations SITE I 
SITE III

\begin{tabular}{c|c|c|r}
\hline Years & & Years & \\
3 & 1 & 3 & 113 \\
4 & 1 & 4 & 119 \\
6 & 3 & 6 & 1,176 \\
7 & 6 & 7 & 1,342 \\
8 & 3 & 8 & 1,018 \\
9 & 6 & 9 & 1,561 \\
10 & 2 & 9.7 & 2,520 \\
14 & 1 & 14 & 1,823 \\
20 & 1 & 20 & 4,130 \\
\hline
\end{tabular}

The curved average of these values for each site class is shown in Table 2. The curves were extended by inspection to twenty years but cannot be considered very accurate beyond fifteen years because of insufficient data. The volumes given are in solid cubic feet, including bark; and no attempt has been made to convert the figures into the board-foot unit. Trees less than twenty years of age are valuable principally for cordwood, and even the manufacturers of small turned articles such as insulator pins, usually purchase the stumpage by the cord. Very little Eucalyptus lumber has been sawn except in an experimental way, and no satisfactory boards have been produced from such young trees.

\section{APPENDIX III}

\section{RAISING EUCALYPTUS FROM SEED}

The planting of large tracts of Eucalyptus trees for growing timber has practically ceased during the last few years, but there is an increasing interest on the part of farmers and ranch owners in the planting of these trees for fuel, windbreaks, prevention of erosion along banks of gulleys, shade for cattle, and beautification of the home grounds. Seedlings of the commoner species can usually be procured from the larger nurseries, but it is often impossible to obtain trees of the rarer varicties which may seem most desirable for the existing conditions. Trees supplied by some nurseries are often kept too long in small pots, which eramps the root system and makes the planting stock unsatisfactory. The following directions, if carefully followed, will enable anyone to raise enough trees for a windbreak or specimen plantation with very little trouble or expense.

Sowing the Seed.-The commonest method for propagating Eucalyptus is to sow the seed in seed boxes about 18 inches square and 4 inches deep, which have been filled almost to the top with light, sandy loam soil. 'The soil should be screened to remove all pebbles and lumps 
and be well firmed in the boxes before the seeds are scattered on the smooth surface. Enough seeds to produce from 200 to 400 seedlings to the box may be sown broadcast over the soil and covered with not more than one-eighth inch of pure sand or clean, fine sawdust. The boxes are then placed in a shady place, preferably under a lath house until germination is complete. Germination should take place within two or three weeks after sowing, during which time careful attention to soil moisture conditions should be given. As damping-off fungi sometimes cause serious lossas during the germination period a minimum amount of water slould be applied. The use of sterile soil is

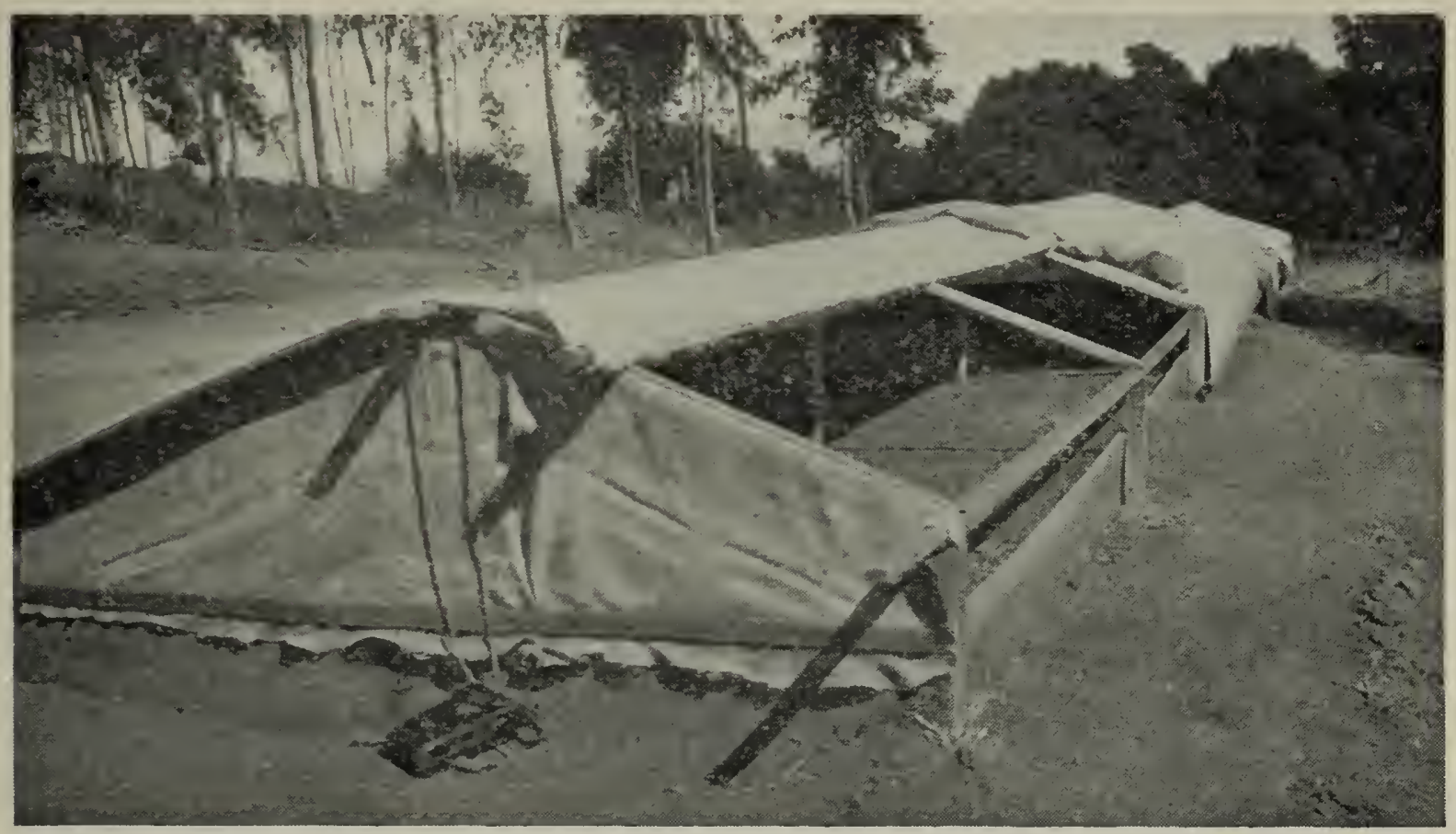

Fig. 26.-One type of seed bed used successfully in San Diego County in growing Sugar Gum and Gray Gum seedlings. The sides are burlap and the top is of cotton cloth. Damping-off loss las been cut to a minimum by withholding water for the first ten days.

advised and careful attention to proper aeration of the boxes should be given. If damping-off starts in the boxes it may often be checked by sprinkling them with a 10 per cent solution of Sulphurated Potassa (Liver of Sulfur).

Seedlings may be raised in standard out-of-door seed beds (fig. 26) with board sides and screen covers instead of seed boxes, in which case a light cotton cloth cover is advisable instead of the regulation screen. This will check evaporation and the beds will require less watering. With some soil conditions it has been found advisable to sprinkle the beds thoroughly after sowing, cover tightly with the cloth, and refrain from watering until after germination is in full progress (about 14 days): With this method the top of the soil dries out and the spread 
of fungous disease is not so apt to occur. The beds or boxes must be carefully watched to see that they do not become so dry as to cause the death of the seedlings.

The best time to sow Eucalyptus seed is from May to July but may vary considerably with different species. The influence of local climate on rate of growth is the controlling factor. Some slow-growing species must be sown earlier, and a few of the more quick-growing may safely be sown in August.

Transplanting.-The roots of Eucalyptus seedlings are so susceptible to drying out that they cannot be successfully planted out in the field unless the roots are enclosed in a ball of earth. Seedlings must therefore be removed from the boxes or seed beds when they are from $21 / 2$ to 4 inches high and placed in separate tar paper pots or perforated cans in which they are left when set in the plantation. The work of placing them in pots or cans is most conveniently done with a small trowel and the root system should be disturbed as little as possible in the process. If plants are left too long in the seed boxes or beds the root system will suffer injury during the transplanting from which they rarely recover. After potting, the young trees should be given careful watering and partial shade for about a month, after which they may gradually be hardened so that they will stand field conditions.

Planting.-Planting should be done about the end of the rainy season when all danger from frost is past and when the trees are about five to eight months old from seed. Some plantations have been successfully started in November or December, but young seedlings are very susceptible to damage by frost and it is rarely advisable to plant so early in the season. Land which is not too steep should be plowed and cultivated for several months before the trees are planted. It is an advantage to grow a crop on the land the year before planting. On steep sites each tree is set in the center of a space about 18 inches across from which sod and weeds have been removed and the soil thoroughly worked up with a mattock.

The pot or can containing the tree is set directly in the ground without disturbing the soil or root system of the seedling. Where tin cans are used it is necessary to cut them down one side and across the bottom with a pair of tin snips in order that they may not interfere with the growth of the tree before they rot away in the soil. The pot or can should be set well into the soil so that the root growth may be able to keep ahead of the drying out of the upper layers of ground during the summer season. After pressing the earth firmly about the tree and container, a mulch of finely pulverized soil should be scattered over the top to diminish evaporation. 
Cultivation.-Most of the groves measured were given two thorough cultivations during the first year. In many groves this was continued through the second growing season. On slopes where horse or tractor cultivation is not possible it is essential that grass and weeds be kept away from the base of each young tree by cultivating a space about two feet square with a grub hoe. This not only relieves the tree from competition with grass and weeds for light and soil moisture, but largely prevents girdling of the trees by mice. In uncultivated plantations this girdling has been a serious problem, sometimes resulting in the loss of 75 per cent of the trees (fig. 27).

Spacing.-With rapid growing species on good sites, a rectangular spacing of 8 by 8 feet ( 680 per acre) or wider has given good results. On poorer sites or when using slower growing species or when the survival per cent is apt to be low, trees may be spaced 7 by 7 or even 6 by 6 feet ( 890 and 1210 per acre). For cordwood production on a short rotation a spacing of 7 by 7 feet will be satisfactory on most sites. To find the number of trees per acre divide 43,560 by the product of planting distances in feet.

With an 8 by 10 foot spacing $\frac{43,560}{80}=544$ trees.

Cost of Planting.-During the period of extensive Eucalyptus planting, from 1908 to 1912, many groves were set out and cared for for two years at a cost of $\$ 25$ to $\$ 40$ per acre exclusive of the cost of the land. Labor costs at that time were considerably lower than at present so that the same work today would probably cost from $\$ 45$ to $\$ 60$ per acre. Several owners of well kept groves have told me that the cost of land, planting and cultivation, plus carrying charges, have totaled approximately $\$ 100$ per acre by the end of ten years. Some groves have cost more than this but it is probably about an average figure for large plantations under reasonably good conditions of soil and management. Therefore, in order to yield a profit, the stumpage value of a Eucalyptus plantation at the end of ten years must be at least approximately $\$ 100$ per acre. A grove which has grown at the rate of four cords per acre per year must have a stumpage value of $\$ 2.50$ per cord in order to pay for itself; while on sites where the rate of growth is slower, the stumpage value must be proportionately higher.

The ranch owner who sets out Eucalyptus trees in a windbreak or along a steep or unused section of good land situated near a good cordwood market, is in a much more favorable position to secure satisfactory returns than the owner of a larger plantation situated on 
inferior land or farther from a good market. In the first case the planting and cultivation can be done in connection with regular farm work and will be less expensive; growth will be faster and the stumpage value will be higher because transportation costs are not so great. A windbreak planting, by the time it is ready to cut, has returned much of the original cost in the protection it has given to adjacent crops, which may properly be taken into consideration in computing its value to the farm. Moreover, it can usually be cut one row at a time with intervals of a year or two between cuts, so that its value as a wind-shield is not impaired, but is actually improved because of the dense growth of young sprouts which spring up after each cutting, renewing the wind mantle near the ground where it is most apt to be impaired by the dropping of branches from the larger trees.

Protection of Plantations.-The need of early cultivation or removal of grass and weeds from around the young trees has been mentioned above as a protection from girdling by rodents. (fig. 27). It is quite as important to keep the young plantation clean as a protection against fire. A bad fire during the early life of a Eucalyptus grove may kill most of the trees and ruin the plantation. As the trees increase in age, leaves, twigs and strips of bark collect on the ground and intensify the danger of a fire spreading through the grove. To remove this litter is usually not feasible nor is it advisable as it retards evaporation from the soil. It should however be recognized as a source of danger. Adequate measures to prevent the starting of fires within the grove should be taken each year well in advance of the danger season. A well equipped and energetic rural fire company is the best insurance against extensive damage by fire and owners of Eucalyptus plantations should be very active in their support of such an organization. Owing to the extremely inflammable nature of Eucalyptus leaves and bark, a fire in hot dry weather if it gets a good start is apt to be very difficult to extinguish before very serious damage is done. Fire in June, 1920, seriously injured over 500 acres of plantations in San Luis Obispo County, and the Arrowhead fire of October, 1922, completely destroyed all of the experimental plantations of the U. S. Forest Service near Del Rosa, San Bernardino County. (See fig. 19).

Cattle and horses should be rigidly excluded from plantations until the trees are large enough to be safe from being trampled or injured by the animals. Later, the grove may well be lightly grazed but much trampling of the soil in wet weather should be guarded against. 
Several fungi are known to attack Eucalyptus in California plantations, but only where heartwood has been exposed because of injury to the cambium layer by fire or some mechanical cause. Trees so infected should be removed from the plantation as soon as possible, as they act as sources of infection for other trees.

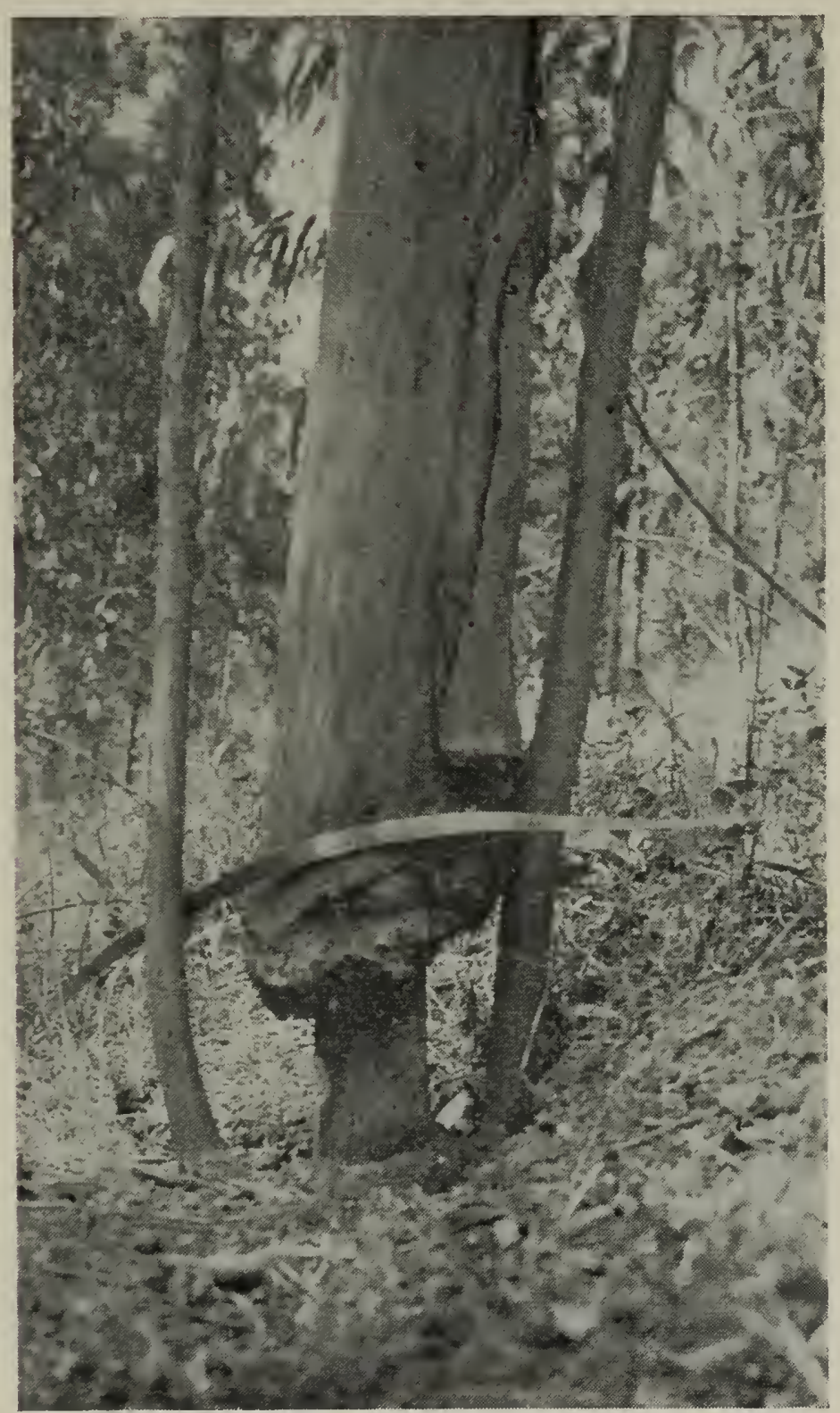

Fig. 27.-This tree has been girdled by mice but is still alive and has produced two sprouts below the point of injury. Girdling by mice has caused the death of large numbers of eucalyptus trees in some plantations. In one Sonoma County grove over 75 per cent of the trees died from this cause. The remedy is clean cultivation around the trees for the first three years. 



\section{REFERENCES ON EUCALYPTUS TREES IN THE UNITED STATES}

Eucalytus. Abbot Kinney, Baumgardt \& Co., Los Angeles, Calif., 1895.

Eucalypts Cultivated in the United States. A. J. McClatchie, U. S. D. A. Bureau of Forestry, Bulletin 35, 1902.

A Handbook for Eucalyptus Planters. G. B. Luli, Calif. State Board of Forestry, Circular 2, 1907.

The Growing of Eucalypts, with detailed bibliography. F. G. Plummer, Proceedings Soc. American Foresters, vol. V, p. 109, 1907.

Forest Planting Leaflet-Eucalypts. U. S. D. A. Forest Service, Circular 59, 1907.

Eucalyptus in California. N. D. Ingham, Calif. Agr. Exp. Sta., Bulletin 196, 1908.

Eucalyptus; Its History, Growth and Utilization. C. H. Sellers, A. J. Johnston Co., Sacramento, Calif., 1910.

A Cultura do Eucalyptos nos Estados Unidos. E. Navarro de Andrade, Rothschild \& Co., Sao Paulo, Brazil, 1910.

Yield from Eucalyptus Plantations in California. L. Margolin, Calif. State Board of Forestry, Bulletin 1, 1910.

Utilization of California Eucalypts. H. S. Betts and C. Stowell Smith, U. S. D. A. Forest Service, Circular 179, 1910.

Tolerance of Eucalyptus for Alkali. R. H. Loughridge, Calif. Agr. Exp. Sta. Bulletin 225, 1911.

The Eucalyptus in Texas. J. H. Arbenz, Austin Printing Co., Austin, Texas, 1911.

Eucalypts in Florida. R. Zon and J. M. Briscoe, U. S. D. A. Forest Service, Bulletin 87, 1911.

Yield and Returns of Blue Gum in California. T. D. Woodbury, U. S. D. A. Forest Service, Circular 210, 1912.

Eucalyptus Lumber-Abstract of U. S. Forest Products, Laboratory Report. H. D. Tiemann, The Hardwood Record, Chicago, Sept. 25 and Oct. 10, 1913.

Investigations on the Oil of Eucalyptus Globulus of California. C. E. Burke and C. C. Scalione, Journal of Industrial and Engineering Chemistry, vol. 7, p. 206, 1915.

Relative Frost Resistance of Eucalyptus in Southern California. E. N. Munns, Journal of Forestry, vol. 16, p. 412, 1918.

Key for Identification of California Eucalypts. H. M. Hall, in Encyclopedia of American Horticulture. Bailey.

An Investigation of the Oil of Eucalyptus Globulus from California. U. S. D. A. Forest Products Laboratory. Mss. by S. A. Mahood and D. E. Cable, 1920.

High Temperatures and Eucalypts. E. N. Munns, Jour. of Forestry, vol. 19, p. 25, 1921.

Key to Eucalypts Grown in California. Mss. by Eric Walther. Files of California Academy of Sciences, San Francisco, 1924. 



\section{BULLETINS}

No.

253. Irrigation and Soil Conditions in the Sierra Nevada Foothills, California.

261. Melaxuma of the Walnut, "Juglans regia."

262. Citrus Diseases of Florida and Cuba Compared with Those of California.

263. Size Grades for Ripe Olives.

268. Growing and Grafting Olive Seedlings.

273. Preliminary Report on Kearney Vineyard Experimental Drain.

275. The Cultivation of Belladonna in California.

276. The Pomegranate.

277. Sudan Grass

278. Grain Sorghums.

279. Irrigation of Rice in California.

280. Irrigation of Alfalfa in the Sacramento Valley.

283. The Olive Insects of California.

285. The Milk Goat in California.

286. Commercial Fertilizers.

287. Vinegar from Waste Fruits.

294. Bean Culture in California.

298. Seedless Raisin Grapes.

304. A Study of the Effects of Freezes on Citrus in California.

310. Plum Pollination.

312. Mariout Barley.

313. Pruning Young Deciduous Fruit Trees.

317. Selections of Stocks in Citrus Propagation.

319. Caprifigs and Caprification.

321. Commercial Production of Grape Syrup.

324. Storage of Perishable Fruit at Freezing Temperatures.

325. Rice Irrigation Measurements and Experiments in Sacramento Valley, 1914-1919.

328. Prune Growing in California.

331. Phylloxera-Resistant Stocks.

334. Preliminary Volume Tables for Second. Growth Redwood.

335. Cocoanut Meal as a Feed for Dairy Cows and Other Livestock.

336. The Preparation of Nicotine Dust as an Insecticide.

339. The Relative Cost of Making Logs from Small and Large Timber.

340. Control of the Pocket Gopher in Cali. fornia.

343. Cheese Pests and Their Control.

344. Cold Storage as an Aid to the Marketing of Plums.
No.

346. Almond Pollination.

347. The Control of Red Spiders in Decidu. ous Orchards.

348. Pruning Young Olive Trees.

349. A Study of Sidedraft and Tractor Hitches.

350. Agriculture in Cut-over Redwood Lands.

351. California State Dairy Cow Competition.

352. Further Experiments in Plum Pollina. tion.

353. Bovine Infectious Abortion.

354. Results of Rice Experiments in 1922.

357. A Self-mixing Dusting Machine for Applying Dry Insecticides and Fungicides.

358. Black Measles, Water Berries, and Related Vine Troubles.

359. Fruit Beverage Investigations.

360. Gum Diseases of Citrus Trees in California.

361. Preliminary Yield Tables for Second Growth Redwood.

362. Dust and the Tractor Engine.

363. The Pruning of Citrus Trees in California.

364. Fungicidal Dusts for the Control of Bunt.

366. Turkish Tobacco Culture, Curing and Marketing.

367. Methods of Harvesting and Irrigation in Relation to Mouldy Walnuts.

368. Bacterial Decomposition of Olives during Pickling.

369. Comparison of Woods for Butter Boxes.

370. Browning of Yellow Newtown Apples.

371. The Relative Cost of Yarding Small and Large Timber.

372. The Cost of Producing Market Milk and Butterfat on 246 California Dairies.

373. Pear Pollination.

374. A Survey of Orchard Practices in the Citrus Industry of Southern California.

375. Results of Rice Experiments at Cor. tena, 1923.

376. Sun-Drying and Dehydration of Walnuts.

377. The Cold Storage of Pears.

378. Stradies on the Nutritional Disease of Poultry Caused by Vitamin A Deficiency.

\section{CIRCULARS}

No.

70. Observations on the Status of Corn Growing in California.

87. Alfalfa.

111. The Use of Lime and Gypsum on California Soils.

113. Correspondence Courses in Agriculture.

117. The Selection and Cost of a Small Pumping Plant.

127. House Fumigation.

129. The Control of Citrus Insects.

136. Melilotus indica as a Green-Manure Crop for California.

144. Oidium or Powdery Mildew of the Vine.

151. Feeding and Management of Hogs.

152. Some Observations on the Bulk Handling of Grain in California.

154. Irrigation Practice in Growing Small Fruit in California.
No.

155. Bovine Tuberculosis.

157. Control of the Pear Scab.

160. Lettuce Growing in California.

161. Potatoes in California.

164. Small Fruit Culture in California.

165. Fundamentals of Sugar Beet Culture under California Conditions.

166. The County Farm Bureau.

167. Feeding Stuffs of Minor Importance.

170. Fertilizing California Soils for the 1918 Crop.

172. Wheat Culture

173. The Construction of the Wood-Hoop Silo.

174. Farm Drainage Methods.

178. The Packing of Apples in California.

179. Factors of Importance in Producing Milk of Low Bacterial Count. 
No.

184. A Flock of Sheep on the Farm.

190. Agriculture Clubs in California.

193. A Study of Farm Labor in California.

198. Syrup from Sweet Sorghum.

199. Onion Growing in California.

202. County Organizations for Rural Fire Control.

203. Peat as a Manure Substitute.

205. Blackleg.

208. Summary of the Annual Reports of the Farm Advisors of California.

209. The Function of the Farm Bureau.

210. Suggestions to the Settler in California.

212. Salvaging Rain-Damaged Prunes.

214. Seed Treatment for the Prevention of Cereal Smuts.

215. Feeding Dairy Cows in California.

217. Methods for Marketing Vegetables in California.

219. The Present Status of Alkali.

220. Unfermented Fruit Juices.

228. Vineyard Irrigation in Arid Climates.

230. Testing Milk, Cream, and Skim Milk for Butterfat.

231. The Home Vineyard.

232. Harvesting and Handling California Cherries for Eastern Shipment.

233. Artificial Incubation.

234. Winter Injury to Young Walnut Trees during 1921-22.

235. Soil Analysis and Soil and Plant Interrelations.

236. The Common Hawks and Owls of Cali. fornia from the Standpoint of the Rancher.

237. Directions for the Tanning and Dressof Furs.

238. The Apricot in California.

239. Harvesting and Handling Apricots and Plums for Eastern Shipment.

240. Harvesting and Handling Pears for Eastern Shipment.

241. Harvesting and Handling Peaches for Eastern Shipment.

242. Poultry Feeding.

243. Marmalade Juice and Jelly Juice from Oitrus Fruits.

244. Central Wire Bracing for Fruit Trees.
No.

245. Vine Pruning Systems.

247. Colonization and Rural Development.

248. Some Common Errors in Vine Pruning and Their Remedies.

249. Replacing Missing Vines.

250. Measurement of Irrigation Water on the Farm.

251. Recommendations Concerning the Common Diseases and Parasites of Poultry in California.

252. Supports for Vines.

253. Vineyard Plans.

254. The Use of Artificial Light, to Increase Winter Egg Production.

255. Leguminous Plants as Organic Fertil. izer in California Agriculture.

256. The Control of Wild Morning Glory.

257. The Small-Seeded Horse Bean.

258. Thinning Deciduous Fruits.

259. Pear By-products.

260. A Selected List of References Relating to Irrigation in California.

261. Sewing Grain Sacks.

262. Cabbage Growing in California.

263. Tomato Production in California.

264. Preliminary Essentials to Bovine Tuberculosis Control.

265. Plant Disease and Pest Control.

266. Analyzing the Citrus Orchard by Means of Simple Tree Records.

267. The Tendency of Tractors to Rise in Front; Causes and Remedies.

268. Inexpensive Lavor-saving Poultry Appliances.

269. An Orchard Brush Burner.

270. A Farm Septic Tank.

271. Brooding Chicks Artificially.

272. California Farm Tenancy and Methods of Leasing.

273. Saving the Gophered Citrus Tree.

275. Marketable California Decorative Greens.

276. Home Canning.

277. Head, Cane, and Cordon Pruning of Vines.

278. Olive Pickling in Mediterranean Coun. tries.

The publications listed above may be had by addressing

College of Agriculture,

University of California,

Berkeley, California. 